Prepared in cooperation with the

U.S. Environmental Protection Agency

ڤEPA

Geomorphic Responses to Stream Channel Restoration at Minebank Run, Baltimore County, Maryland, 2002-08

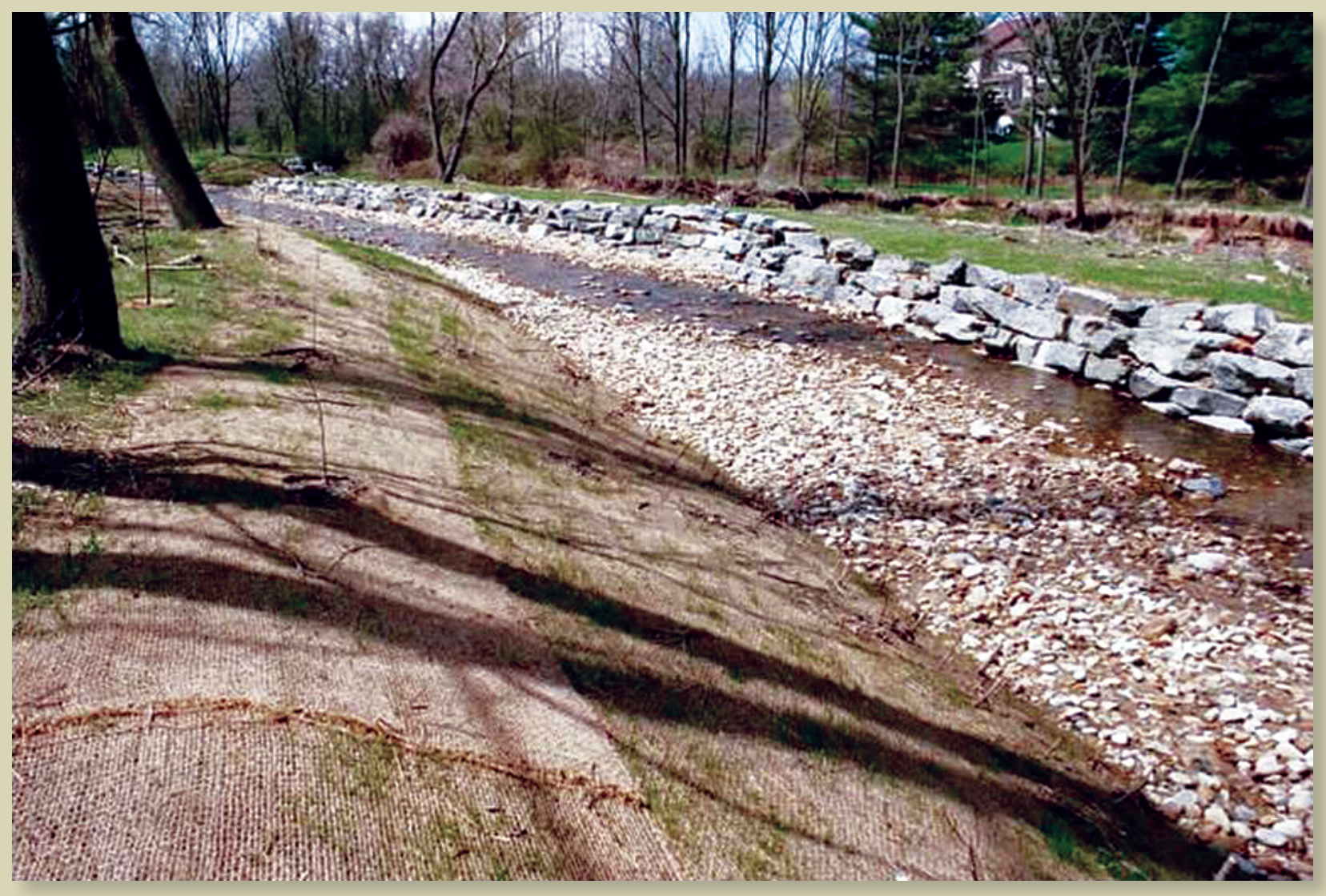

Scientific Investigations Report 2012-5012

U.S. Department of the Interior

U.S. Geological Survey 
Cover. View looking upstream at restored section of Minebank Run in Cromwell Valley Park, Baltimore County, Maryland, with original stream channel visible in the background, 2005. (Photograph by Kenneth Jewell, U.S. Environmental Protection Agency.) 


\section{Geomorphic Responses to Stream Channel Restoration at Minebank Run, Baltimore County, Maryland, 2002-08}

By Edward J. Doheny', Jonathan J.A. Dillow', Paul M. Mayer ${ }^{2}$, and Elise A. Striz ${ }^{3}$

\footnotetext{
${ }^{1}$ U.S. Geological Survey, Baltimore, Maryland

${ }^{2}$ U.S. Environmental Protection Agency, Office of Research and Development, Ada, Oklahoma

${ }^{3}$ Formerly of U.S. Environmental Protection Agency, Office of Research and Development, Ada, Oklahoma
}

Prepared in cooperation with the

U.S. Environmental Protection Agency

Scientific Investigations Report 2012-5012 


\section{U.S. Department of the Interior \\ KEN SALAZAR, Secretary \\ U.S. Geological Survey \\ Marcia K. McNutt, Director}

U.S. Geological Survey, Reston, Virginia: 2012

For more information on the USGS - the Federal source for science about the Earth, its natural and living resources, natural hazards, and the environment, visit http://www.usgs.gov or call 1-888-ASK-USGS

For an overview of USGS information products, including maps, imagery, and publications, visit http://www.usgs.gov/pubprod

To order this and other USGS information products, visit http://store.usgs.gov

Any use of trade, product, or firm names is for descriptive purposes only and does not imply endorsement by the U.S. Government.

Although this report is in the public domain, permission must be secured from the individual copyright owners to reproduce any copyrighted materials contained within this report.

Suggested citation:

Doheny, E.J., Dillow, J.J.A., Mayer, P.M., and Striz, E.A., 2012, Geomorphic responses to stream channel restoration at Minebank Run, Baltimore County, Maryland, 2002-08: U.S. Geological Survey Scientific Investigations Report 2012-5012, $61 \mathrm{p}$. 


\section{Contents}

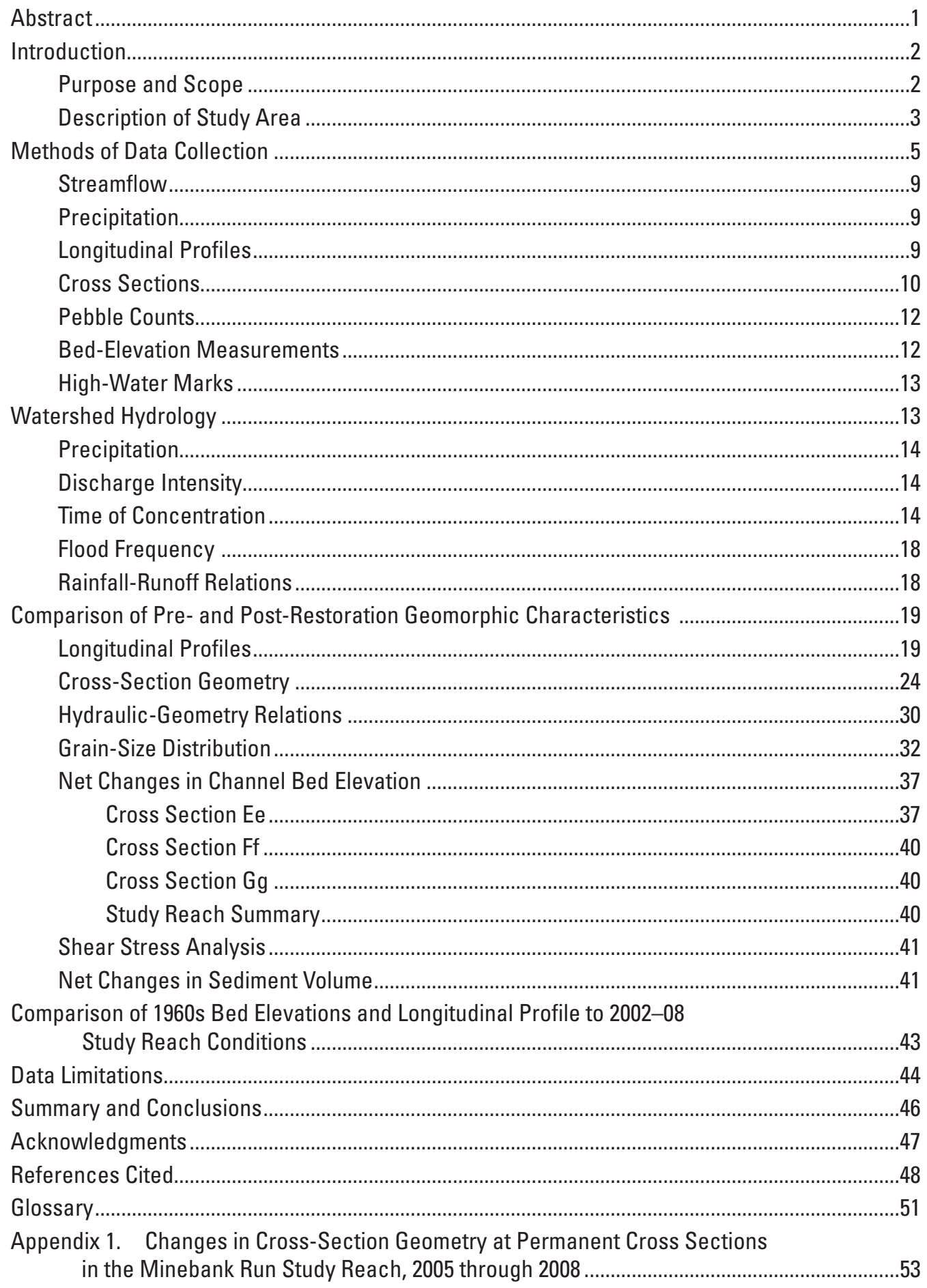




\section{Figures}

1. Map showing location of Minebank Run watershed and study area, Baltimore County, Maryland

2. Photograph showing view looking downstream at section of Minebank Run that was restored in 1998-99, upstream of the Baltimore Beltway (I-695), 2003.

3. Map showing detailed view of Minebank Run watershed and study reach,

Baltimore County, Maryland

4-5. Photographs showing-

4. View looking upstream at unrestored section of Minebank Run in Cromwell Valley Park downstream of the Baltimore Beltway (I-695), 2003

5. View looking upstream at restored section of Minebank Run in Cromwell Valley Park with original stream channel visible in the background, 2005.

6-7. Maps showing-

6. Location of continuous-record streamgage, crest-stage partial-record stations, precipitation gage, and well transects along the Minebank Run study reach, Baltimore County, Maryland

7. Locations of permanent cross sections that were established and surveyed in the Minebank Run study reach at Cromwell Valley Park, 2002-08.

8-9. Graphs showing-

8. Plot of grain-size distribution developed from the pebble count at cross section Ff, Minebank Run study reach, May 9, 2005.

9. Relations between instantaneous peak discharge and ratios of daily-mean and event-mean discharges, pre- and post-restoration, at station 0158397967, Minebank Run near Glen Arm, Maryland

10. Map showing locations and contributing areas of watersheds draining to station 01585200, West Branch Herring Run at Idlewylde, Maryland and station 0158397967, Minebank Run near Glen Arm, Maryland

11-12. Graphs showing-

11. Maximum rainfall intensity against time of concentration for Minebank Run and West Branch Herring Run for selected pre- and post-restoration storm events, water years 2002 through 2008.

12. Linear relation between log-transformed annual peak discharges at Minebank Run and coincident peaks at West Branch Herring Run

13. Aerial photograph showing Minebank Run study reach in Cromwell Valley

Park prior to channel restoration.

14-15. Graphs showing-

14. Longitudinal profile of channel features in the Minebank Run study reach from field survey conducted on March 30, 2005

15. Comparison of riffle, pool, and run distribution and percentages in the Minebank Run study reach before and after channel restoration, 2002 through 2008

16-24. Graphs showing post-restoration cross-section geometry at-

16. Permanent cross section Aa, April 2005 through April 2008

17. Permanent cross section Bb, April 2005 through April 2008 
18. Permanent cross section Cc, April 2005 through April $2008 \ldots \ldots \ldots \ldots \ldots \ldots \ldots \ldots \ldots \ldots \ldots \ldots . . .25$

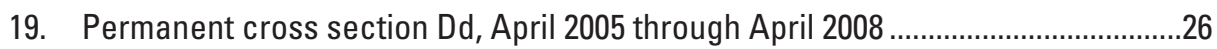

20. Permanent cross section Ee, April 2005 through April 2008.....................................26

21. Permanent cross section $\mathrm{Ff}$, April 2005 through April 2008 .....................................26

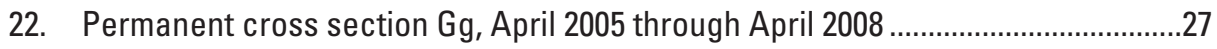

23. Permanent cross section Hh, April 2005 through April $2008 \ldots \ldots \ldots \ldots \ldots \ldots \ldots \ldots \ldots \ldots \ldots \ldots . . . . .27$

24. Permanent cross section li, April 2005 through April 2008 ……...............................27

25. Map showing summary of post-restoration geomorphic conditions in the Minebank Run study reach, 2005 through 2008 ...

26-27. Graphs showing-

26. Comparison of pre- and post-restoration hydraulic-geometry relations of cross-sectional area, channel width, mean channel depth, and mean velocity against discharge using discharge measurements of less than 10 cubic feet per second at U.S. Geological Survey station 0158397967, Minebank Run near Glen Arm, Maryland ...

27. Comparison of composite pebble counts for Minebank Run study reach above Sherwood Bridge before and after channel restoration, 2003 through 2008

28-30. Graphs showing comparison of particle-size distributions at-

28. Cross section Ee, 2002 through 2008 38

29. Cross section $\mathrm{Ff}, 2002$ through 2008

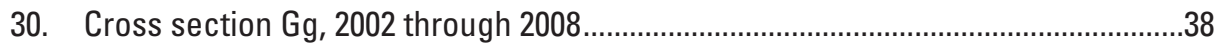

31-33. Graphs showing net changes in bed elevation over time at-

31. Cross section Ee, January 2, 2003 through 0 ctober 7, 2008 .39

32. Cross section Ff, December 3, 2002 through October 7, $2008 \ldots \ldots \ldots \ldots \ldots \ldots \ldots \ldots \ldots \ldots \ldots \ldots . . . . .39$

33. Cross section $\mathrm{Gg}$, January 2, 2003 through September 15, $2008 \ldots \ldots \ldots \ldots \ldots \ldots \ldots \ldots \ldots . . . . .39$

34-36. Graphs showing -

34. Boundary shear stress versus mean velocity at the peak discharge during storm events in the Minebank Run study reach, November 2001 through September 2004, and December 2004 through August 2008

35. Generalized pre-restoration channel bed profile upstream of Sherwood Bridge, Minebank Run study reach, early 1960s and 2002 . .45

36. Generalized post-restoration channel bed profile upstream of Sherwood Bridge, Minebank Run study reach, 2005 and 2008

\section{Tables}

1. Summary of streamflow statistics for U.S. Geological Survey station 0158397967, Minebank Run near Glen Arm, Maryland, water years 2002-08

2. Total precipitation recorded in vicinity of the Minebank Run study reach during water years 2002 through 2008

3. Dates, locations, and longitudinal stationing used for the longitudinal-profile surveys in the Minebank Run study reach, 2002-08.

4. Basic station information for permanent cross sections located in the Minebank Run study reach after restoration, 2005-08. 
5. Grain-size distribution and computation of percent finer from pebble count at cross section Ff, Minebank Run study reach, May 9, 2005.

6. Time of concentration for 38 selected storms in the Minebank Run and West Branch Herring Run watersheds, water years 2002 through 2008

7. Comparison of flood-frequency analyses for Minebank Run, based on station data from 1997-2004 and normalized from long-term estimates at West Branch Herring Run .....

8. Runoff amounts and percentages for 41 selected storm events at U.S. Geological Survey station 0158397967, Minebank Run near Glen Arm, Maryland, water years 2002 through 2008.

9. Slopes of the channel bed and water surface in the Minebank Run study reach from longitudinal profile surveys, 2002-08.

10. Percentages of riffles, pools, and runs in the Minebank Run study reach from longitudinal-profile surveys, 2002-08.

11. Changes in cross-section geometry at permanent cross-section $\mathrm{Hh}$, Minebank Run study reach, 2005 through 2008.

12. Summary of variability of cross-sectional characteristics in the Minebank Run study reach, 2005 through 2008.

13. Cumulative distribution of grain sizes, in percent finer, for surficial bed material at permanent cross section locations in the Minebank Run study reach, May 2005.

14. Cumulative distribution of grain sizes, in percent finer, for surficial bed material at permanent cross section locations in the Minebank Run study reach, October 2006

15. Cumulative distribution of grain sizes, in percent finer, for surficial bed material at permanent cross section locations in the Minebank Run study reach, April 2008

16. Median particle diameter from pebble counts associated with each permanent cross section in the Minebank Run study reach, 2002 through 2008

17. Grain-size distributions and computation of percent finer from composite pebble counts at all permanent cross sections, Minebank Run study reach, 2003 through 2008

18. Data variables and boundary shear stress computations for 11 storm runoff events in the Minebank Run study reach, December 2004 through August 2008

19. Changes in volume, in cubic feet, between cross-sectional surveys for reach segments associated with each permanent cross section, Minebank Run study reach, December 2002 through April 2008

20. Estimates of sediment volume and rate of change in sediment volume stored or removed from the Minebank Run study reach, December 2002 through April 2008

21. Thalweg elevations at cross section $\mathrm{Hh}$ from longitudinal profile surveys between 2002 and 2008, and corresponding differences from early 1960s channel bed elevation 


\section{Conversion Factors and Vertical Datums}

\begin{tabular}{lcl}
\hline Multiply & By & To obtain \\
\hline inch (in.) & Length & \\
inch (in.) & 2.54 & centimeter $(\mathrm{cm})$ \\
foot (ft) & 25.4 & millimeter $(\mathrm{mm})$ \\
mile (mi) & 0.3048 & meter $(\mathrm{m})$ \\
\hline \multicolumn{3}{c}{ kilometer $(\mathrm{km})$} \\
\hline acre & 1.609 & \\
acre & Area & square meter $\left(\mathrm{m}^{2}\right)$ \\
square mile $\left(\mathrm{mi}^{2}\right)$ & 4,047 & square kilometer $\left(\mathrm{km}^{2}\right)$ \\
square mile $\left(\mathrm{mi}^{2}\right)$ & 0.004047 & hectare $($ ha) \\
\hline & 259 & square kilometer $\left(\mathrm{km}^{2}\right)$ \\
\hline cubic foot $\left(\mathrm{ft}^{3}\right)$ & 2.59 & \\
\hline & Volume & acre-feet $(\mathrm{acre}-\mathrm{ft})$ \\
\hline cubic foot per second $\left(\mathrm{ft}^{3} / \mathrm{s}\right)$ & 0.000023 & cubic meter per second $\left(\mathrm{m}^{3} / \mathrm{s}\right)$ \\
inch per hour (in/hr) & Flow rate & millimeter per hour $(\mathrm{mm} / \mathrm{hr})$ \\
\hline & 0.02832 & \\
\hline pound, avoirdupois $(\mathrm{lb})$ & 25.4 & kilogram $(\mathrm{kg})$ \\
ton, short $(2,000 \mathrm{lb})$ & Mass & kilogram $(\mathrm{kg})$ \\
\hline
\end{tabular}

Temperature in degrees Fahrenheit $\left({ }^{\circ} \mathrm{F}\right)$ may be converted to degrees Celsius $\left({ }^{\circ} \mathrm{C}\right)$ as follows:

$$
{ }^{\circ} \mathrm{C}=\left({ }^{\circ} \mathrm{F}-32\right) / 1.8
$$

Vertical coordinate information is referenced to the National Geodetic Vertical Datum of 1929 (NGVD 29).

Horizontal coordinate information is referenced to the North American Datum of 1983 (NAD 83).

Altitude, as used in this report, refers to distance above the vertical datum.

\section{Abbreviations}

$\begin{array}{ll}\text { CIES } & \text { Cary Institute of Ecosystem Studies } \\ \mathbf{d 5 0} & \text { Median particle diameter } \\ \text { I-695 } & \text { Interstate 695, Baltimore Beltway } \\ \text { NAD 83 } & \text { North American Datum of 1983 } \\ \text { NGVD 29 } & \text { National Geodetic Vetical Datum of 1929 } \\ \text { R }^{2} & \text { Coefficient of determination } \\ \text { USEPA } & \text { U.S. Environmental Protection Agency } \\ \text { USGS } & \text { U.S. Geological Survey }\end{array}$





\title{
Geomorphic Responses to Stream Channel Restoration at Minebank Run, Baltimore County, Maryland, 2002-08
}

\author{
By Edward J. Doheny, Jonathan J.A. Dillow, Paul M. Mayer, and Elise A. Striz
}

\section{Abstract}

Data collected from 2002 through 2008 by the U.S. Geological Survey, in cooperation with the U.S. Environmental Protection Agency, were used to assess geomorphic characteristics and geomorphic changes over time in a reach of Minebank Run, a small urban watershed near Towson, Maryland, prior to and after its physical restoration in 2004 and 2005. Data collection included continuous-record streamflow and precipitation; surveyed elevations of the channel bed, water surface, and bank features; surveyed cross sections; pebble counts from the channel bed; measurements of bed elevation over time; and high-water marks from storm runoff events.

To provide hydrologic context to the geomorphic monitoring that was conducted during the study period, precipitation, discharge intensity, time of concentration, flood frequency, and rainfall-runoff relations were investigated. Hydrologic conditions were found to be comparable for the pre- and post-restoration monitoring periods. Flood frequency analysis indicated that the largest peak flows that occurred in the Minebank Run watershed during 2002-08 could represent events of lower probability when compared to a longer peak-flow record in the adjacent West Branch Herring Run watershed.

Longitudinal profiles of the channel bed and water surface indicated differences in the distribution and location of riffles, pools, and runs during 2002-08. During both the preand post-restoration monitoring periods, the analyses indicated that on average, the stream is maintaining the overall slope of the channel bed and water surface at about 1 percent, despite considerable changes in the percentages of riffles, pools, and runs, and changes in the distribution and location of these features.

Post-restoration, lateral erosion has been reduced with fewer indications of channel widening. Flood flows can now inundate sections of the overbank area, and also bypass the main channel in small sections of the study reach, which was not possible before restoration. Much of the post-restoration geomorphic variability is due to alternating patterns of sediment storage and removal, and shifting of the channel thalweg, in contrast to channel degradation and widening, and lateral erosion from receding cut banks observed during the prerestoration monitoring. Reduced variability in cross-sectional area and mean depth between surveys conducted from 2006 through 2008 indicates that the stream channel could be establishing a dynamic equilibrium and a more stable geometry after the initial geomorphic response observed in 2005 and 2006, just after restoration in 2004 and 2005.

Most channel geometry variables had moderate to strong linear relations with discharge. Pre-restoration, the strongest relation was between cross-sectional area and discharge. Post-restoration, the strongest relation was between mean flow velocity and discharge.

Composite particle-size analyses of the channel bed from pebble counts over time indicated that sources of fine sediment, possibly from bank erosion, still exist in the watershed despite restoration of the stream channel. The abundance of relatively small bed material sizes in combination with flashy streamflow from urban and suburban runoff likely contributes to the considerable changes in grain-size distribution and alternating periods of storage and transport of sand and gravel.

Sequential measurements of bed elevation over time in three selected locations of the study reach indicated a period of considerable vertical adjustment between September 2005 and December 2006 based on post-restoration monitoring. One of the three selected locations was in one of the most geomorphically unstable sections of the study reach before restoration, and was found to be considerably less prone to rapid and extreme changes in bed elevation after restoration of the stream channel.

An analysis of boundary shear stress was conducted by use of measured channel-geometry variables and water-surface slopes in the vicinity of the continuous-record streamgage. The results indicated that, post-restoration, larger increases in mean velocity were required to initiate sediment transport in the stream channel.

Pre-restoration, sediment volume computations indicated that sediment was being removed from the study reach, with the largest sediment volume and rate of removal occurring during December 2002 through July 2003. Post-restoration, an alternating pattern of sediment removal and storage was 
observed, with the largest sediment volume and rate of removal occurring during April 2005 to December 2005, just after completion of the restoration. The largest volumes and rates of sediment storage during the post-restoration period occurred between December 2005 and September 2006. The storm and flood of June 25, 2006 was a likely factor in the volume of sediment stored in the study reach during this period.

Comparing an early 1960s channel bed profile to those developed during 2002-08 confirmed that the stream channel has maintained an overall slope of about 1 percent for greater than 40 years. Comparisons of bed elevations between the early 1960s and 2002 indicate that the channel bed degraded within an approximate range of $1.3 \mathrm{ft}$ (feet) to $5.0 \mathrm{ft}$, and with possible local scour of up to $5.6 \mathrm{ft}$ near a sanitary sewer pipe that was exposed within the channel bed. In the postrestoration condition, the channel bed is still about $0.8 \mathrm{ft}$ to 4.8 $\mathrm{ft}$ lower than bed elevations from the early 1960s at approximately equivalent locations along the profile.

\section{Introduction}

Minebank Run, a small urban stream in Baltimore County, Maryland, is a tributary to the Gunpowder River in the Chesapeake Bay watershed that drains approximately 3.27 $\mathrm{mi}^{2}$ (square miles) (Doheny and others, 2007). During two phases of work occurring between 1999 and 2005, Minebank Run was the focus of physical restoration efforts by the Baltimore County Department of Environmental Protection and Resource Management (Lutz, 2006; Doheny and others, 2007). One of the primary goals of the physical restoration was to re-establish geomorphic stability ${ }^{1}$ of the stream channel.

Urban streams, such as Minebank Run, commonly display flashy streamflow due to rapid runoff from impervious surfaces. The flashy streamflow can alter the bed and banks of the stream channel considerably over time. The erosive power that is generated in urban streams often leads to degradation and widening of stream channels, bank failure, increased sediment supply, and instability of riffle and pool features along the channel profile (Paul and Meyer, 2001). In order to address these problems, stream channel restorations are often designed to adjust channel sinuosity and pattern, stabilize channel dimension, reshape banks and re-introduce riparian vegetation, and stabilize the longitudinal profile of the channel.

In April 2001, the U.S. Environmental Protection Agency (USEPA) began investigating opportunities in the Baltimore metropolitan area to study streams that were targeted for restoration to improve physical function and habitat. Baltimore was a focus area for stream restoration research because of a large number of projects that had been carried out since the early 1990s. Minebank Run was selected for study because of the opportunity to study potential water-quality benefits

\footnotetext{
${ }^{1}$ Words in bold are defined in the glossary section at the end of the report.
}

from implementation of specific restoration practices, such as re-planting vegetation in riparian zones, reconfiguring of meanders and point bars, reconstruction of flood plains, and physical movement of sections of the channel within the valley. In October 2001, the U.S. Geological Survey (USGS), the USEPA, and the Cary Institute of Ecosystem Studies (CIES) jointly initiated a study to investigate the effects of stream restoration on stream hydrology, denitrification, and overall water quality in a selected reach of Minebank Run (Groffman and others, 2005; Doheny and others, 2006; Striz and Mayer, 2008; Kaushal and others, 2008; Mayer and others, 2010; Harrison and others, 2011). Instrumentation, including a continuousrecord streamgage and precipitation gage, was installed by USGS to document the stream hydrology. In response to rapid changes in channel geometry and elevations of channel features, as well as the rate of lateral migration of the stream channel observed during the first year of the study, the USGS was also tasked with measuring and documenting the geomorphic changes within the Minebank Run study reach before and after physical restoration (Doheny and others, 2007).

\section{Purpose and Scope}

Data collected from water years 2002 through 2008 were used to assess and compare pre-and post-restoration geomorphic characteristics and changes in these characteristics over time in the Minebank Run study reach. Pre-restoration geomorphic monitoring in the study reach occurred between November 2001 and August 2004. Channel restoration construction occurred in the watershed between June 2004 and February 2005, with the majority of the physical construction in the study reach occurring between October and December 2004. Post-restoration geomorphic monitoring occurred between December 2004 and September 2008. For purposes of hydrologic evaluation, October 2004 is considered to be the break between the pre- and post-restoration monitoring periods.

The report describes conventional techniques that were used for geomorphic data collection and comparative analysis of the data. The report also includes a brief overview of watershed hydrology and flood frequency during the period of investigation. Analyses conducted for this report include pre- and post-restoration comparisons of (1) longitudinal profiles of the channel bed and water surface; (2) changes in cross-section geometry due to aggradation, degradation, and lateral erosion; (3) hydraulic-geometry relations of the stream channel; (4) grain-size distribution of the channel bed; (5) net changes in bed elevation at selected locations over time; (6) boundary shear stress based on cross-section geometry and water-surface slope in the vicinity of the continuous-record streamgage; and (7) estimates of net change in sediment volume stored or removed from the study reach between cross-sectional surveys. The report also presents a comparison of bed elevations and a longitudinal profile from the 1960s to study reach conditions found between water years 2002 and 2008. 


\section{Description of Study Area}

Minebank Run is a 3.27- $\mathrm{mi}^{2}$ sub-watershed of the Gunpowder Falls located in the south-central section of Baltimore County, Maryland, approximately $4.7 \mathrm{mi}$ (miles) northwest of the Fall Line in the Piedmont Physiographic Province (fig. 1). The watershed lies between $39^{\circ} 23^{\prime} 34^{\prime \prime}$ and $39^{\circ} 25^{\prime} 26^{\prime \prime}$ north latitude, and between $76^{\circ} 32^{\prime} 07^{\prime \prime}$ and $76^{\circ}$ $35^{\prime} 40^{\prime \prime}$ west longitude. The headwaters are located on the east side of Towson, Maryland. The stream flows roughly in a northeasterly direction and confluences with Gunpowder Falls near the town of Loch Raven, approximately $0.30 \mathrm{mi}$ downstream of the lower dam on Loch Raven Reservoir (Doheny and others, 2006; Doheny and others, 2007).

The Minebank Run watershed is bounded by 2 ridges that are oriented approximately from southwest to northeast, with a broad, lightly sloping valley in between. The ridges are comprised of metamorphic rocks, namely schists and quartzites. The valley is underlain by marble that is mostly covered by colluvium and alluvium, with the exception of some parts of the stream channel where the marble is exposed. The valley width ranges from approximately $0.6 \mathrm{mi}$ near the headwater and outlet areas, to about $1.5 \mathrm{mi}$ near the mid-point of the watershed. The watershed ranges in elevation from about 400 to $500 \mathrm{ft}$ (feet) above the National Geodetic Vertical Datum of 1929 (NGVD 29) at the drainage boundaries, to about 150 to $400 \mathrm{ft}$ above NGVD 29 in the stream valley. Relief ranges from 100 to $300 \mathrm{ft}$ in most areas of the watershed (Doheny and others, 2006; Doheny and others, 2007).

As of 2004, the Minebank Run watershed consisted of a restored section and an unrestored section. The upper $0.80 \mathrm{mi}^{2}$ of the watershed, which is upstream of the Baltimore Beltway (I-695) (fig. 1), was restored in 1998 and 1999. Restoration was initiated in the lower $2.47 \mathrm{mi}^{2}$ of the watershed during June 2004 and was completed in about February 2005

(Doheny and others, 2006; Doheny and others, 2007).

In the section of the watershed that was restored during 1998 and 1999, the dimension, pattern, and profile of the stream channel were reconstructed for purposes of improving stability. Riffle and pool sequences were re-created by selective placement of rock weirs (Rosgen, 1993), which were also intended to control sediment supply in the watershed. Where possible, flood plains were created to allow flood flows to spread out in the valley and reduce the energy directed at the channel bed. Channel-bank slopes were reduced in many locations and natural vegetation was planted on the banks. Riprap was used to harden channel banks in selected locations to protect sewer infrastructure located in the valley. Low to moderate channel sinuosity was maintained throughout the restored reaches to reduce the potential for lateral bank erosion and failure (fig. 2) (Doheny and others, 2007).

The study reach at Minebank Run drains $2.06 \mathrm{mi}^{2}$ (fig. 3) and was selected for monitoring of both pre-restoration and post-restoration conditions related to the 2004-05 channel restoration. The length of the study reach is approximately 1,800 $\mathrm{ft}$. At this location, land use in the watershed is approximately
80.6 percent urban, and 16.9 percent forested or open space (Baltimore County Department of Environmental Protection and Resource Management, 2000). The largest percentages of urban land use and impervious surfaces are in the headwaters of the watershed, upstream of I-695. Most of these highly impervious areas are at higher elevations near the southern section of the drainage boundary. These areas, in combination with direct runoff from I-695, are the likely sources of increased storm runoff that causes the stream stage and corresponding discharge to increase and decrease very quickly during storm events (Doheny and others, 2006; Doheny and others, 2007).

Prior to restoration in 2004 and 2005, much of the study reach at Minebank Run was entrenched and over-widened (Doheny and others, 2006). Most of the stream energy was being directed at the channel bed and banks, with little or no ability for the streamflow to overtop the channel banks and spread out onto the flood plain. The channel banks were steeply sloped in many locations with numerous occurrences of bank failure and lateral erosion. The channel sinuosity was fairly low, but several locations in the study reach had large meanders that coincided with very unstable channel banks and a highly mobile and unstable channel bed (fig. 4) (Doheny and others, 2006; Doheny and others, 2007).

Prior to restoration in 2004 and 2005, the bed material in the study reach consisted of a mixture of sand, gravel, cobbles, and a few small boulders. In this section of the watershed, much of the flood plain and channel bed lie within the deposits of alluvium and colluvium mapped by Crowley and Cleaves (1974). Few bedrock outcrops were visible in the study reach because of the deposits of alluvium and colluvium. Bank material included some deposits of sand and gravel, with greater percentages of silt and clay than in the channel bed (Doheny and others, 2007).

Restoration techniques similar to those described above were used in the lower section of the Minebank Run watershed during 2004 and 2005 to restore what had been a degraded and over-widened stream channel (Doheny and others, 2006; Doheny and others, 2007). The channel bed was reconstructed with large gravel and small cobbles that were trucked in from outside the watershed. In addition to the restoration techniques described above, the stream channel was physically moved within the valley in two locations of the study reach that had large, highly sinuous meanders. In addition to reducing the sinuosity, the original stream channel was left in place as an overflow channel in these locations, thus allowing a percentage of stormflows to bypass the newly restored stream channel in these locations (fig. 5).

The study reach selected for geomorphic investigation also overlapped a study reach where shallow groundwater and water quality were monitored between 2001 and 2008 (fig. 6) (Mayer and others, 2003; Groffman and others, 2005; Doheny and others, 2006; Doheny and others, 2007; Striz and Mayer, 2008; Kaushal and others, 2008; Mayer and others, 2010; Harrison and others, 2011). The study design for groundwater and water-quality monitoring included nests of three 


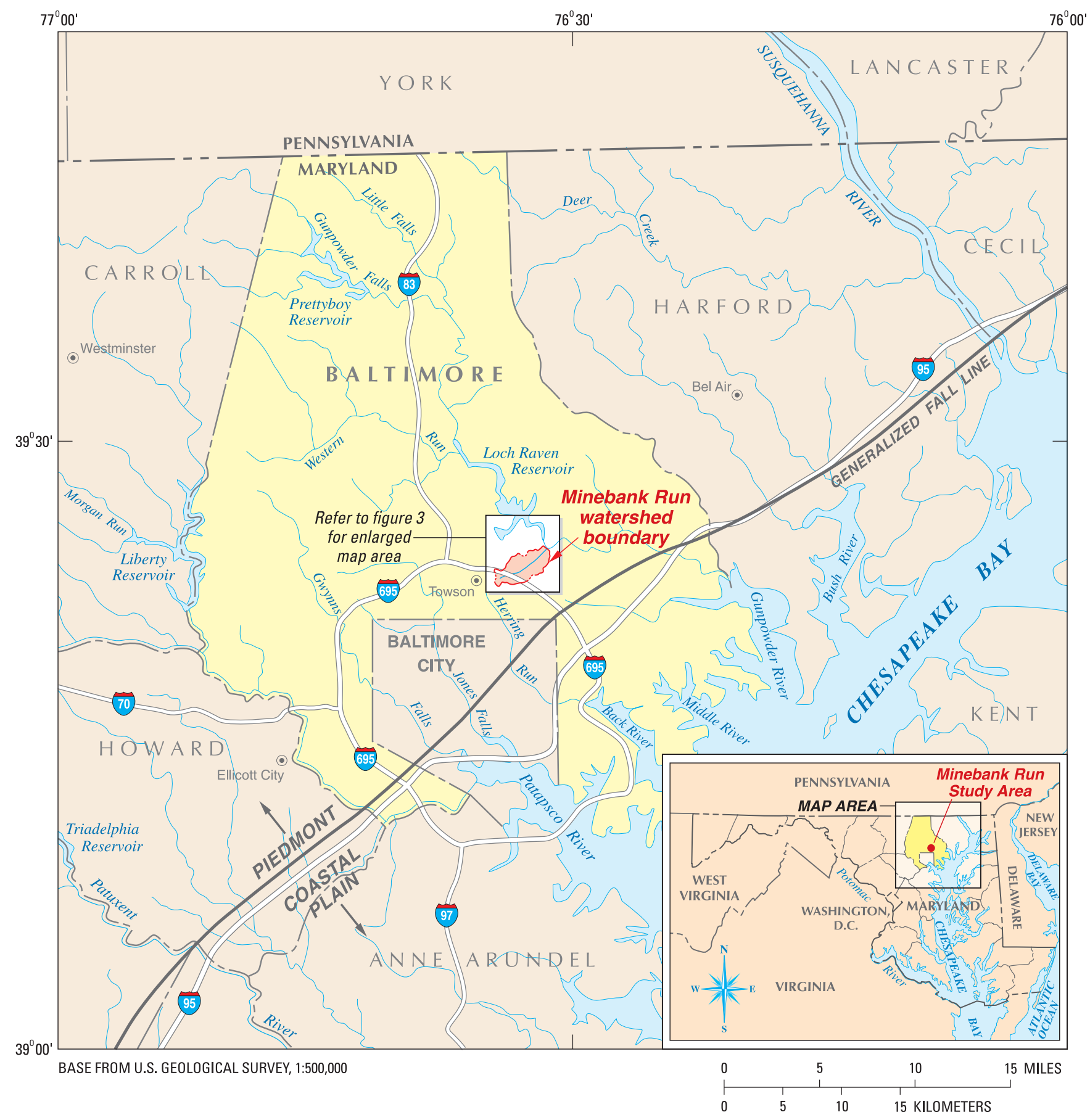

Figure 1. Location of Minebank Run watershed and study area, Baltimore County, Maryland. 


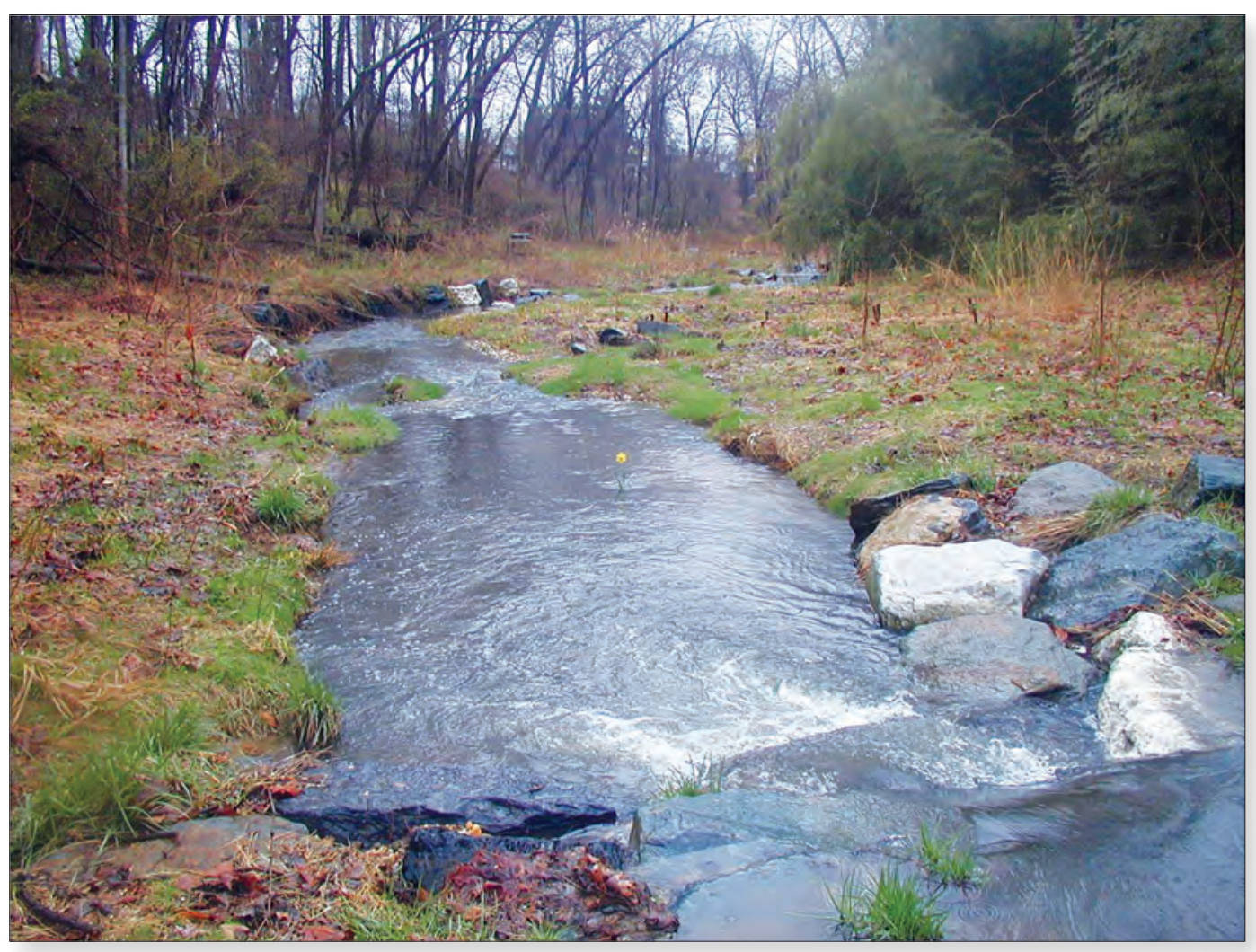

Figure 2. View looking downstream at section of Minebank Run that was restored in 1998-99, upstream of the Baltimore Beltway (I-695), 2003. (Photograph by Paul M. Mayer, U.S. Environmental Protection Agency.)

1-in. (inch)-diameter piezometers that were installed 2 to 6 $\mathrm{ft}$ below the surface of the channel bed, and 3.75 to $11.85 \mathrm{ft}$ below the land surface on the channel banks in three selected locations along Minebank Run (fig. 6) (Doheny and others, 2006). The tops of the piezometers in the channel bed also were used in the geomorphic investigation as measuring points for tracking channel-bed elevations over time (Doheny and others, 2007).

\section{Methods of Data Collection}

Geomorphic data were collected in the Minebank Run study reach to quantify pre- and post-restoration streamchannel characteristics, and to assess changes to the stream channel prior to and after restoration. Descriptions of methods used for data collection during 2002 through 2004 are presented in Doheny and others (2007). Similar techniques were used for continued data collection in the study reach between 2005 and 2008.
A continuous-record streamgage (USGS station number 0158397967, Minebank Run near Glen Arm, Maryland) (fig. 6) has provided 5-minute, unit-value stage and discharge data in the Minebank Run study reach since October 2001. A continuous-record precipitation gage (USGS station number 392449076331100) (fig. 6) has provided 5-minute, unit value precipitation data in the Minebank Run watershed near the study reach since October 2001. Pre- and post-restoration surveys were conducted to document existing cross-section geometry and changes in channel geometry over time. Surveys of the longitudinal profile were conducted to determine the elevations of channel features throughout the study reach. Pebble counts were conducted to determine grain-size distributions of the surficial bed material. Measuring point elevations from instream piezometers were used as the elevation control in selected cross-section locations to determine the net change in channel-bed elevation over time. High-water marks were measured at the streamgage and at selected downstream locations in the study reach to determine the water-surface slope during storm events (Doheny and others, 2007). 


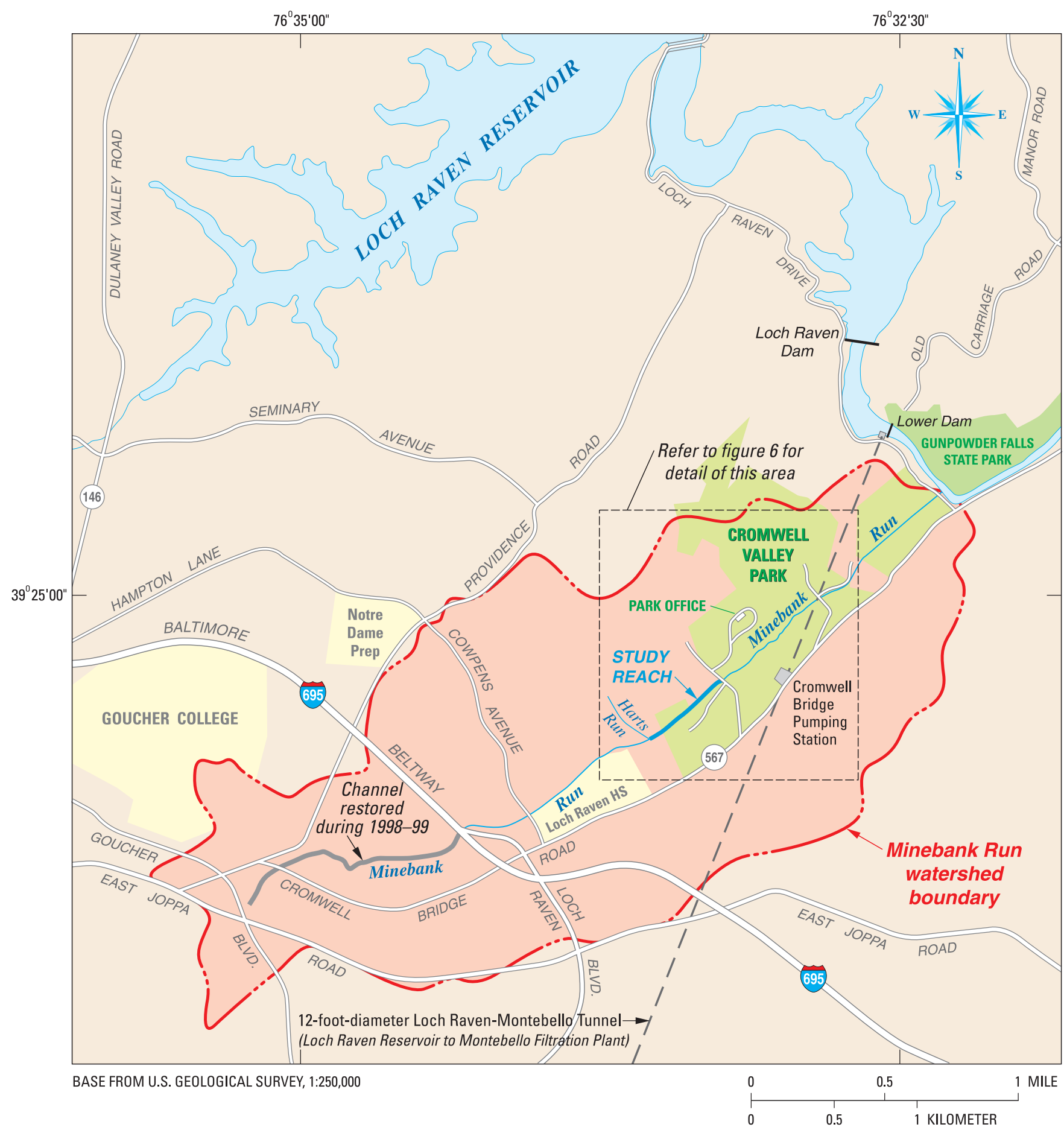

Figure 3. Detailed view of Minebank Run watershed and study reach, Baltimore County, Maryland. 


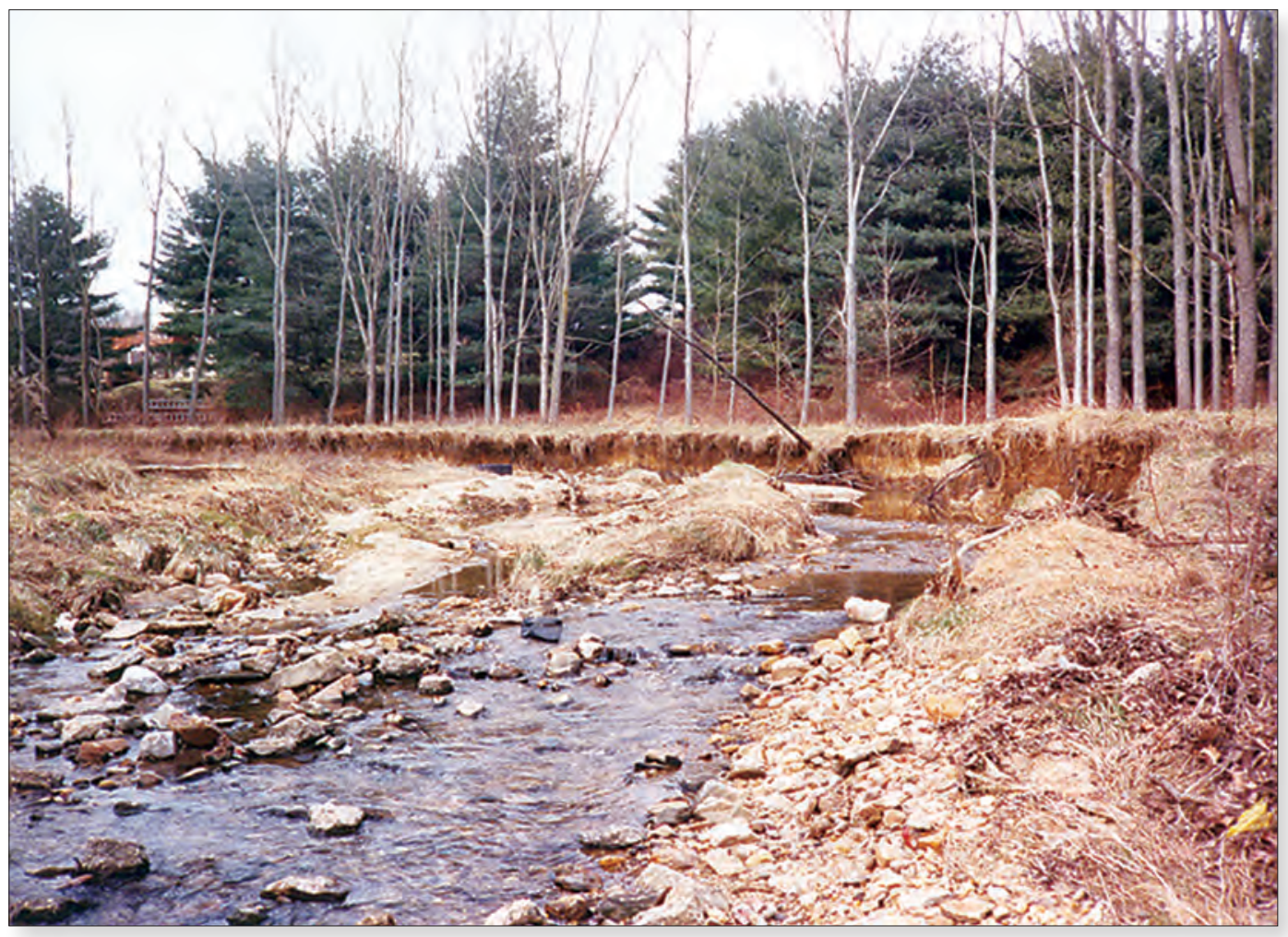

Figure 4. View looking upstream at unrestored section of Minebank Run in Cromwell Valley Park downstream of the Baltimore Beltway (I-695), 2003. (Refer to figure 6 for location of photograph.) (Photograph by Edward J. Doheny, U.S. Geological Survey.)

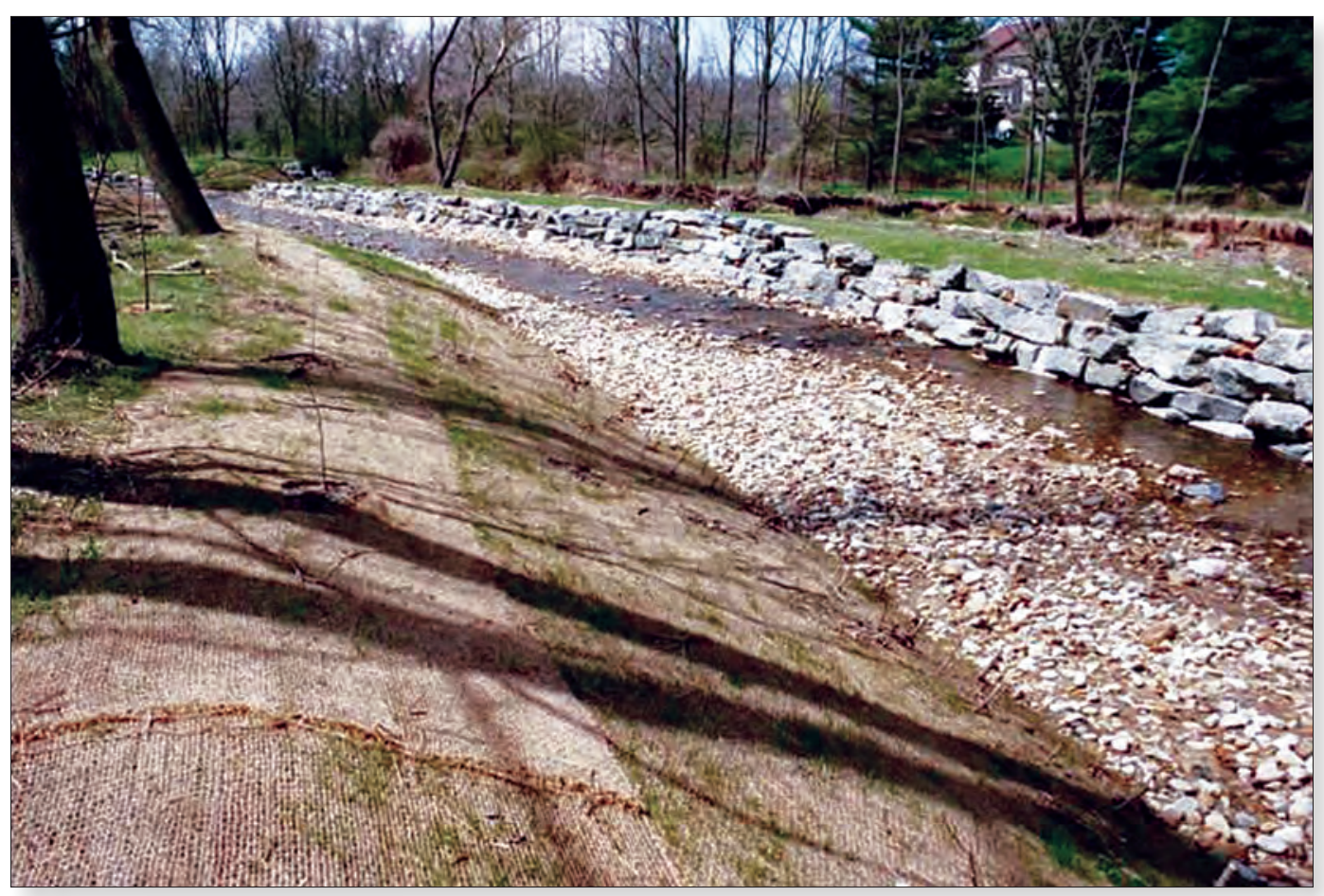

Figure 5. View looking upstream at restored section of Minebank Run in Cromwell Valley Park with original stream channel visible in the background, 2005. (Refer to figure 6 for location of photograph.) (Photograph by Kenneth Jewell, U.S. Environmental Protection Agency.) 


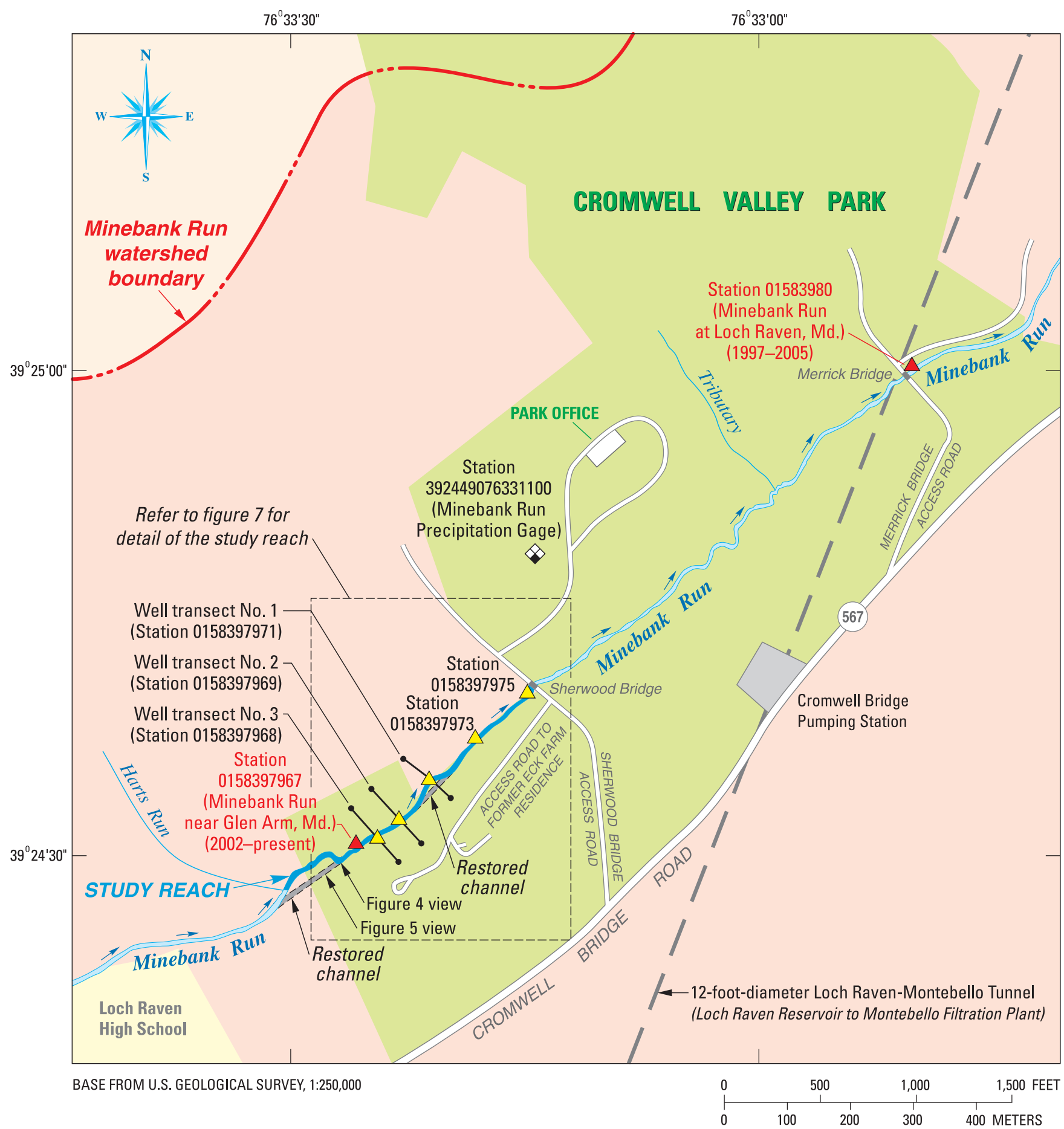

EXPLANATION

$\bullet$ Well transect (consisting of 2-inch monitoring wells on each flood plain, and 1-inch piezometer nests in the channel bed and on each channel bank)

Minebank Run study reach

ロニニニロ Restored channel

Figure 6. Location of continuous-record streamgage, crest-stage partial-record stations, precipitation gage, and well transects along the Minebank Run study reach, Baltimore County, Maryland. 


\section{Streamflow}

Since October 2001, continuous-record streamflow data have been collected at USGS station 0158397967 in the Minebank Run study reach using standard USGS streamgaging techniques (Carter and Davidian, 1968; Buchanan and Somers, 1968; Doheny and others, 2007). Streamflow statistics for station 0158397967, Minebank Run near Glen Arm, Maryland for water years 2002 through 2008 are presented in table 1 (U.S. Geological Survey, 2009).

\section{Precipitation}

A precipitation gage was installed near the Minebank Run study reach to obtain continuous-record precipitation data that correspond to the Minebank Run streamgage located nearby (Doheny and others, 2006). Because the streamgage location was not suitable for monitoring precipitation due to an abundance of large trees in the vicinity of the station, the precipitation gage was installed in a row crop field approximately $0.3 \mathrm{mi}$ from the streamgage (fig. 6). Five-minute unit-value precipitation data were collected in this location beginning in October 2001. General station information for the precipitation gage was previously published in Doheny and others (2006).

Geomorphic monitoring in the Minebank Run study reach occurred during an alternating period of relatively wet and dry hydrologic conditions. Mean annual precipitation for the Baltimore region is about 42 in. (Maryland State Climatologist Office, 2011). On the basis of precipitation data collected in the vicinity of the Minebank Run study reach, total water year precipitation ranged from about 33 in. to more than 64 in. during the period of study (table 2) (Doheny and others, 2006).

\section{Longitudinal Profiles}

Longitudinal profiles of the Minebank Run study reach were conventionally surveyed on a yearly basis from April 2002 through April 2008 to determine the relative elevations and consistency of the channel bed, water surface, and other channel features (Doheny and others, 2007). The reach where the longitudinal profile surveys were conducted was located in between the Sherwood Bridge and just upstream of the confluence with Harts Run (fig. 6). Channel-bed and watersurface elevations were surveyed along the study reach. All surveys were conducted using the same longitudinal stationing so that comparisons of profiles from different years would be possible. Survey elevations were measured at break points between riffles, pools, and runs in order to define these features individually. Distances were measured along the thalweg between surveyed points on the streambed, which allowed definition of the lengths and distribution of riffles, pools, and runs in the reach (Doheny and others, 2007). The surveys from 2002 through 2004 represented the pre-restoration condition of the stream channel. The 2005 survey represented
Table 1. Summary of streamflow statistics for U.S. Geological Survey station 0158397967, Minebank Run near Glen Arm, Maryland, water years 2002-08.

$\left[\mathrm{mi}^{2}\right.$, square mile; $\mathrm{ft}^{3} / \mathrm{s}$, cubic feet per second; [(ft $\left.\left.3 / \mathrm{s}\right) / \mathrm{mi}^{2}\right]$, cubic feet per second per square mile]

\begin{tabular}{lc}
\hline & $\begin{array}{c}\text { Station 0158397967, } \\
\text { Minebank Run near } \\
\text { Glen Arm, Maryland }\end{array}$ \\
\hline Drainage area $\left(\mathrm{mi}^{2}\right)$ & 2.06 \\
\hline Annual mean discharge $\left(\mathrm{ft}^{3} / \mathrm{s}\right)$ & 2.81 \\
\hline Highest annual mean discharge $\left(\mathrm{ft}^{3} / \mathrm{s}\right)$ & 4.34 \\
& $(2004)$ \\
\hline Lowest annual mean discharge $\left(\mathrm{ft}^{3} / \mathrm{s}\right)$ & 1.15 \\
\hline Highest daily mean discharge $\left(\mathrm{ft}^{3} / \mathrm{s}\right)$ & $(2002)$ \\
\hline Lowest daily mean discharge $\left(\mathrm{ft}^{3} / \mathrm{s}\right)$ & 106 \\
\hline Maximum instantaneous peak $\mathrm{flow}^{3}$ & (October 8,2005$)$ \\
\hline discharge $\left(\mathrm{ft}^{3} / \mathrm{s}\right)$ & 0.04 \\
\hline Minimum instantaneous low flow & 1,400 \\
discharge $\left(\mathrm{ft}^{3} / \mathrm{s}\right)$ & (June 25,2006$)$ \\
\hline Annual runoff $\left(\mathrm{inches}^{2}\right)$ & 0.04 \\
\hline Annual runoff $\left[\left(\mathrm{ft}^{3} / \mathrm{s}\right) / \mathrm{mi}^{2}\right]$ & (August 17,2002$)$ \\
\hline
\end{tabular}

Table 2. Total precipitation recorded in vicinity of the Minebank Run study reach during water years 2002 through 2008.

\begin{tabular}{|cc|}
\hline Water year & $\begin{array}{c}\text { Total precipitation } \\
\text { (inches) }\end{array}$ \\
\hline 2002 & 32.95 \\
\hline 2003 & 64.19 \\
\hline 2004 & 51.70 \\
\hline 2005 & 36.72 \\
2006 & 60.30 \\
2007 & 33.27 \\
\hline 2008 & 54.22 \\
\hline
\end{tabular}


the post-construction condition of the stream channel, approximately 1 month after the restoration work in the watershed was completed in February 2005. The surveys from 2006 through 2008 represented the post-restoration condition of the stream channel. The methods and procedures used for the surveys are described in detail in Leopold (1994). Dates, locations, and longitudinal stationing used for the longitudinalprofile surveys are summarized in table 3 .

\section{Cross Sections}

Permanent cross sections were established in the Minebank Run study reach to assess physical changes to the stream channel before and after restoration. Nine cross sections were established with monumented endpoints over a distance of approximately $1,300 \mathrm{ft}$ prior to restoration, and approximately $1,260 \mathrm{ft}$ after restoration. The reach contained the continuous-record streamgage, and the three transects of wells and piezometers that were established for other technical aspects of the study (fig. 6). The cross sections were established in straight sections of the channel, or in straight sections between meanders, and were aligned perpendicular to the direction of the streamflow. The cross sections were vertically referenced to NGVD 29. The cross sections were initially surveyed in December 2002 and re-surveyed during June and July of 2003, and again during January and February of 2004, just prior to the start of the channel restoration work that began in June 2004 (Doheny and others, 2007). Basic station information, including the longitudinal stationing, latitudes, and longitudes, for the nine permanent cross sections in the Minebank Run study reach prior to restoration can be found in Doheny and others (2007).

The cross sections were surveyed in April 2005 to document the post-construction geometry and dimension of the stream channel. The cross sections were re-surveyed in November and December 2005, September 2006, August 2007, and April 2008 to document post-restoration conditions. Three cross-section endpoints were lost during the restoration work and had to be replaced, and two cross sections, Ee and Ii, had to be re-established in new locations after completion of the restoration work because sections of the stream channel were physically relocated (fig. 7). The new locations were within approximately $100 \mathrm{ft}$ of the original cross sections. Basic station information including the post-restoration longitudinal stationing, latitudes, and longitudes, for the nine permanent cross sections in the Minebank Run study reach is summarized in table 4.

Table 3. Dates, locations, and longitudinal stationing used for the longitudinal-profile surveys in the Minebank Run study reach, 2002-08.

[ft, feet]

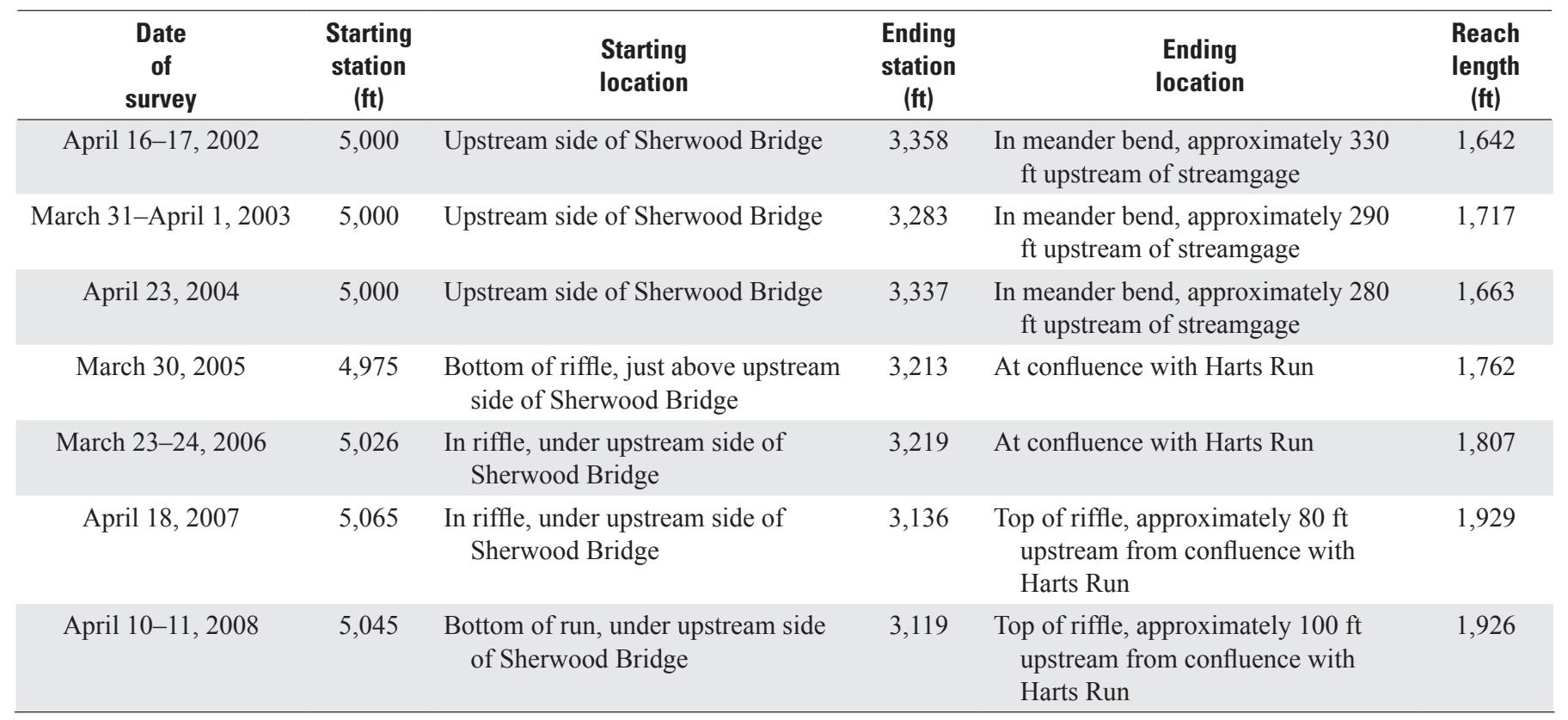




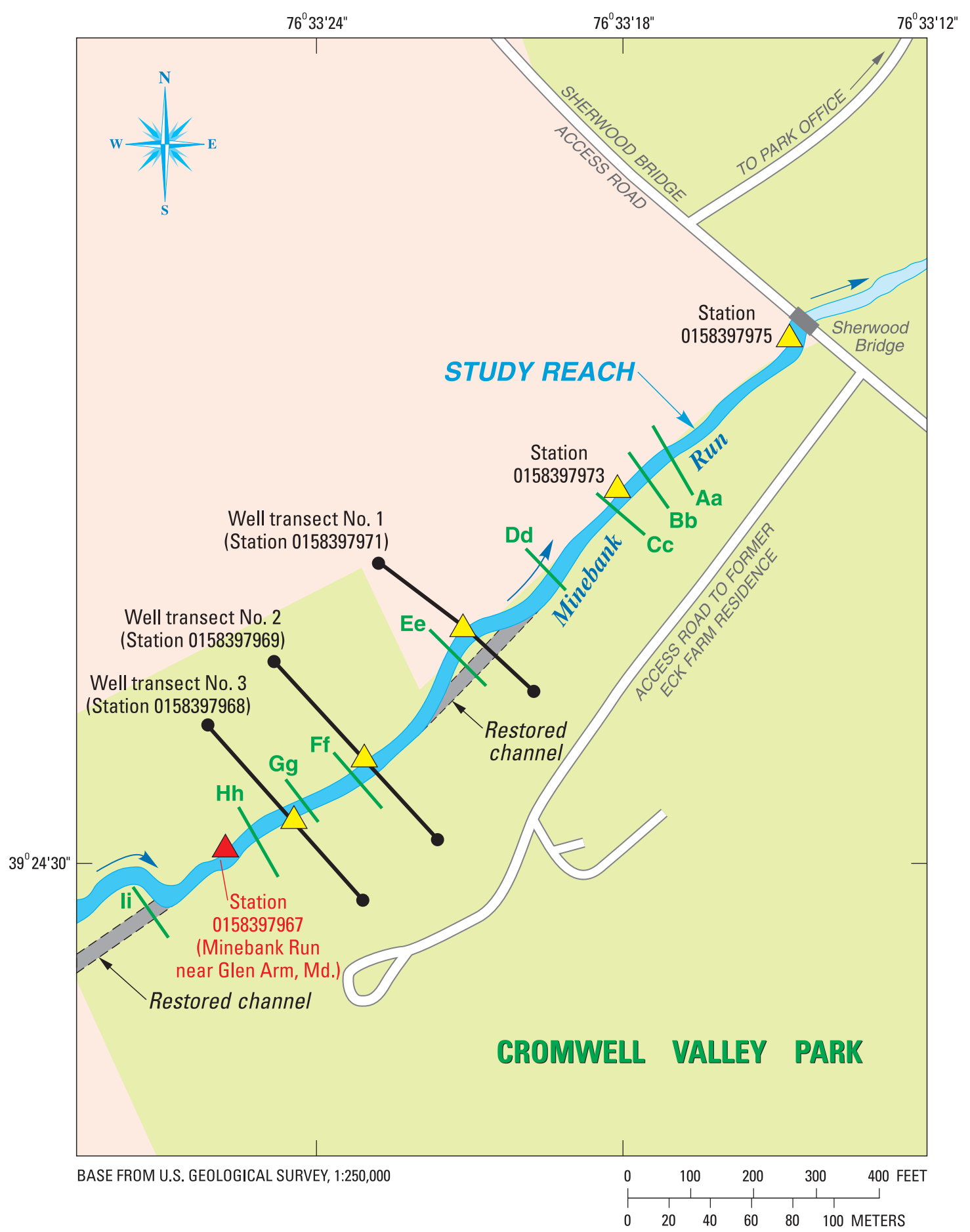

EXPLANATION

${ }^{0158397967} \triangle$ Continuous-record streamgage and identification number

${ }^{0158397973} \triangle$ Crest-stage partial-record station with staff gage and identification number

Minebank Run study reach $\bullet$ Well transect (consisting of 2-inch monitoring wells on each flood plain, and 1-inch piezometer nests in the channel bed and on each channel bank)

$\mathrm{Hh} \longrightarrow$ Permanent cross section

-

Figure 7. Locations of permanent cross sections that were established and surveyed in the Minebank Run study reach at Cromwell Valley Park, 2002-08. 


\section{Pebble Counts}

One-hundred-particle pebble counts were conducted at each of the permanent cross section locations in the study reach to characterize the surficial channel-bed sediment over time. Pebble counts were initially conducted in May 2002 at the three well transects in the study reach that correspond to cross sections Ee, Ff, and Gg. A pebble count at all nine cross sections was conducted in May-June 2003 prior to restoration of the stream channel (Doheny and others, 2007). After restoration, pebble counts were conducted at the nine cross sections in May 2005, October 2006, and April 2008.

The pebble counts were made by randomly picking up particles from the channel bed throughout the entire width of the main channel at an interval of about 1 particle per foot of cross section, and measuring the intermediate axis, or width, of the particle that was picked up in $\mathrm{mm}$ (millimeters) (Leopold, 1994; Harrelson and others, 1994; Doheny and others, 2007). The particles were tallied according to size class (silt, sand, gravel, cobbles, or boulders) and used to directly determine grain-size distributions for the surface of the channel bed at each cross section and for the study reach (Doheny and others, 2007). An example of a grain-size distribution and computation of percent finer from a pebble count at cross section Ff in the Minebank Run study reach on May 9, 2005 is shown in table 5. A plot of the grain-size distribution developed from the pebble count is shown in figure 8 .

\section{Bed-Elevation Measurements}

Net changes in bed elevation were determined over time at three locations in the study reach where instream piezometers had been installed to monitor shallow groundwater levels and water quality (Mayer and others, 2003; Mayer and others, 2010). These locations closely coincide with the locations of permanent cross sections Ee, Ff, and Gg (fig. 7). The distance from the top of the piezometers to the channel bed was measured every 1-2 months and after major storm events between December 2002 and July 2004. The instream piezometers were then removed in July 2004 as the instream work associated with the channel restoration was getting started. The instream piezometers were re-installed in the channel bed in September 2005 , several months after completion of the channel restoration work. The measurements from the top of the piezometers to the channel bed were then repeated in the three locations every 1-2 months and after major storm events between September 2005 and October 2008. Since the measuring point elevations were surveyed and related to NGVD 29, net bed elevations could be determined over time at the piezometer locations by making these periodic measurements (Doheny and others, 2007).

Table 4. Basic station information for permanent cross sections located in the Minebank Run study reach after restoration, 2005-08.

[ft, feet; ${ }^{\circ}$, degrees; ', minutes; “, seconds]

\begin{tabular}{|c|c|c|c|c|}
\hline $\begin{array}{l}\text { Cross } \\
\text { section }\end{array}$ & $\begin{array}{l}\text { Longitudinal station } \\
\text { (ft) }\end{array}$ & $\begin{array}{l}\text { Description of } \\
\text { cross section } \\
\text { location }\end{array}$ & $\begin{array}{l}\text { Left } \\
\text { cross section endpoint } \\
\text { latitude-longitude } \\
\left({ }^{\circ} \text { ‘) }\right.\end{array}$ & $\begin{array}{l}\text { Right } \\
\text { cross section endpoin } \\
\text { latitude-longitude } \\
\left({ }^{\circ} \cdots\right)\end{array}$ \\
\hline Aa & $4,727.0$ & Downstream of meander & $\begin{array}{l}392442.6 \\
763314.8\end{array}$ & $\begin{array}{lll}39 & 24 & 41.1 \\
76 & 33 & 13.5\end{array}$ \\
\hline $\mathbf{B b}$ & $4,668.0$ & Upstream of meander & $\begin{array}{l}392442.1 \\
763315.8\end{array}$ & $\begin{array}{l}392442.4 \\
763313.8\end{array}$ \\
\hline Dd & $4,394.0$ & Upstream of meander & $\begin{array}{l}392440.2 \\
763318.0\end{array}$ & $\begin{array}{lll}39 & 2438.9 \\
7633 & 16.2\end{array}$ \\
\hline $\mathbf{E e}$ & $4,234.0$ & Downstream of meander & $\begin{array}{l}392438.5 \\
763318.5\end{array}$ & $\begin{array}{l}392437.9 \\
763317.5\end{array}$ \\
\hline Hh & $3,678.0$ & Downstream of meander & $\begin{array}{l}392435.8 \\
763324.0\end{array}$ & $\begin{array}{ll}39 & 2435.1 \\
763323.2\end{array}$ \\
\hline Ii & $3,463.0$ & Between two meanders & $\begin{array}{lll}39 & 2434.6 \\
76 & 3326.1 \\
\end{array}$ & $\begin{array}{l}392434.2 \\
763325.8\end{array}$ \\
\hline
\end{tabular}




\section{High-Water Marks}

High-water marks were obtained in the study reach during water years 2002 through 2008 by use of crest-stage gages that were installed at selected locations (Buchanan and Somers, 1968). These marks were used along with electronically logged data from the continuous-record streamgage to determine peak water-surface elevations that occurred in the study reach between site visits. The crest-stage gages were serviced during regular maintenance visits to the streamgage and after major storm events. All high-water marks that were registered on the crest-stage gages were documented and logged. The hydrographs from the continuous-record streamgage were referenced to determine the date of the storm that left the highwater mark and the discharge associated with that storm.

The distance between crest-stage gages along the thalweg of the stream channel was measured so that water-surface slopes could be determined at a range of stages and discharges by use of the high-water marks. Because the reach in the vicinity of the streamgage was the most linear section of the study reach, the streamgage and the crest-stage gage immediately downstream of this station were used for determination of representative water-surface slopes in the study reach (Doheny and others, 2007).

During the pre-restoration phase of the study, five creststage gages were used in selected locations of the study reach along with an additional one that was associated with the continuous-record streamgage (figs. 6, 7). All crest-stage gages downstream of well transect no. 3 were removed in 2004 prior to the channel restoration work, and were not replaced as the reach immediately downstream of the streamgage was deemed most critical for determining representative water-surface slopes in the study reach.

\section{Watershed Hydrology}

For comparisons of various geomorphic characteristics in the pre- and post-restoration periods of the overall study to be meaningful, some hydrologic context for the study period must be provided. In this way, it is possible to determine whether noted changes may have been caused by implementation of the channel-restoration design, changes in hydrologic conditions, or both. Basic watershed characteristics, such as drainage area and basin slope, did not change appreciably during the study period. Land-use type and distribution were also unchanged, as the watershed is located in a small area of builtout residential and commercial development and protected park land (Baltimore County Department of Environmental Protection and Resource Management, 2000). As a result, these watershed characteristics were not considered as potential causes of any hydrologic or geomorphic changes observed in the stream channel during the study period. Precipitation, discharge intensity, time of concentration, flood frequency, and rainfall-runoff relations were investigated for the study period to provide some hydrologic context to the geomorphic monitoring that was conducted between 2002 and 2008.

Table 5. Grain-size distribution and computation of percent finer from pebble count at cross section Ff, Minebank Run study reach, May 9, 2005.

[mm, millimeters; \%, percent, ---, not applicable]

\begin{tabular}{|c|c|c|c|}
\hline $\begin{array}{c}\text { Particle } \\
\text { description }\end{array}$ & $\begin{array}{l}\text { Particle } \\
\text { size limit } \\
(\mathrm{mm})\end{array}$ & $\begin{array}{l}\text { Item } \\
\text { count }\end{array}$ & $\begin{array}{c}\text { Cumulative } \\
\text { percent finer } \\
(\%)\end{array}$ \\
\hline Silt & 0.062 & 0 & 0 \\
\hline Sand & 2 & 4 & 4.0 \\
\hline Very fine gravel & 4 & 0 & 4.0 \\
\hline Fine gravel & 8 & 4 & 7.9 \\
\hline Medium gravel & 16 & 12 & 19.8 \\
\hline Coarse gravel & 32 & 20 & 39.6 \\
\hline Very coarse gravel & 64 & 26 & 65.3 \\
\hline Small cobbles & 128 & 31 & 96.0 \\
\hline Large cobbles & 256 & 4 & 100.0 \\
\hline Small boulders & 512 & 0 & 100.0 \\
\hline Medium boulders & 1,024 & 0 & 100.0 \\
\hline Large boulders & 2,048 & 0 & 100.0 \\
\hline Very large boulders & 4,096 & 0 & 100.0 \\
\hline TOTAL & --- & 101 & --- \\
\hline
\end{tabular}




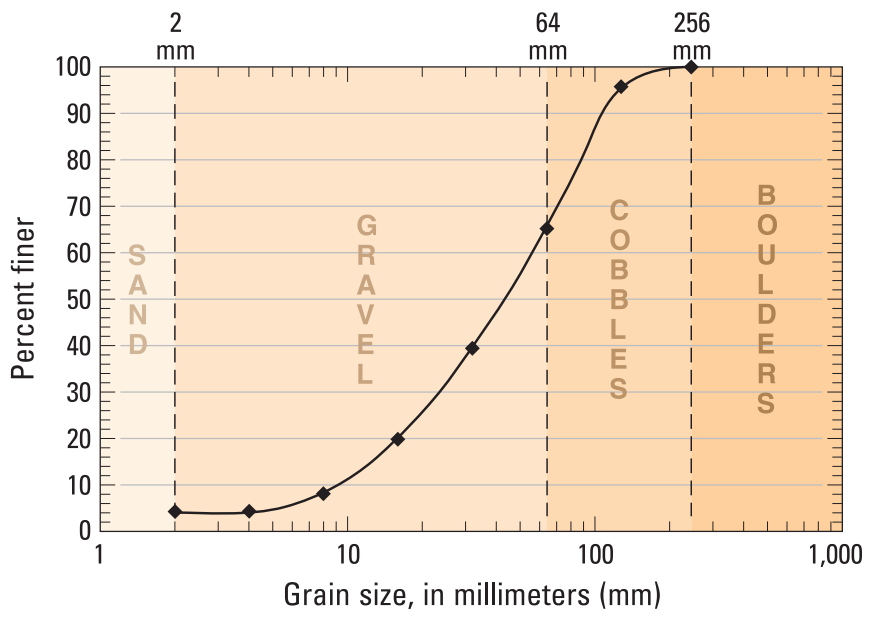

Figure 8. Plot of grain-size distribution developed from the pebble count at cross section Ff, Minebank Run study reach, May 9, 2005.

\section{Precipitation}

There is considerable annual variation in the precipitation input and streamflow output from Minebank Run as shown by data presented in tables 1 and 2. During the study period, the watershed received the largest amount of precipitation during water year 2003, but produced the largest annual mean discharge of $4.34 \mathrm{ft}^{3} / \mathrm{s}$ (cubic feet per second) during water year 2004 (which experienced the median annual precipitation for the study period). Annual mean discharge during water year 2003 was $4.26 \mathrm{ft}^{3} / \mathrm{s}$, or approximately 1.9 percent less than water year 2004, despite nearly 12.5 additional in. of precipitation that fell during water year 2003. The explanation for this occurrence is that each of the other three water years (2003, 2006, and 2008) with larger, above-average (47.62 in.) annual precipitation was immediately preceded by years with below-average annual precipitation. During the study, only water year 2004 experienced both above-average precipitation and succeeded a year of above-average precipitation.

The effects of annual variability notwithstanding, data from table 2 indicate that the variation in annual precipitation totals was comparable for the pre- and post-restoration periods. Similarly, storm durations, intensities, and precipitation totals were comparable during the two study periods. Storm durations in both periods ranged from a half hour to several days. Maximum storm intensity recorded during water years 2002 through 2004 was $4.68 \mathrm{in} / \mathrm{h}$ (inches per hour) (0.39 in. during one 5-minute period on April 19, 2002), whereas the maximum intensity during water years 2005 through 2008 was $4.08 \mathrm{in} / \mathrm{h}(0.34 \mathrm{in}$. during one 5 -minute period on July 23 , 2008). It should be noted that several high-intensity and longduration precipitation events were not recorded during the post-restoration period because of several equipment malfunctions, so exact data values to define the full range of conditions during that time are not available. In these cases, daily precipitation totals were estimated using data from two nearby non-recording precipitation gages that were placed in the field to provide back-up data to the recording gage.

\section{Discharge Intensity}

Doheny and others (2006) quantified flashy streamflow in Minebank Run during water years 2002 through 2004 by comparing a ratio of peak discharge to daily-mean discharge for flood events. For purposes of this discussion, construction work in the study reach section of the watershed was completed around December 2004, and the boundary between the pre- and post-restoration periods for the study reach was considered to be between approximately December 2004 and February 2005. The pre-restoration period peak discharges used in this analysis ranged from $247 \mathrm{ft}^{3} / \mathrm{s}$ to 1,390 $\mathrm{ft}^{3} / \mathrm{s}$, whereas daily-mean discharges ranged from $8.0 \mathrm{ft}^{3} / \mathrm{s}$ to $50 \mathrm{ft}^{3} / \mathrm{s}$. The maximum ratio for a storm in this time period was 51.4, occurring on May 17, 2004. By comparison, in the post-restoration period from approximately February 2005 through September 2008, peak discharges ranged from 214 $\mathrm{ft}^{3} / \mathrm{s}$ to $1,400 \mathrm{ft}^{3} / \mathrm{s}$, daily-mean discharges ranged from $5.8 \mathrm{ft}^{3} / \mathrm{s}$ to $106 \mathrm{ft}^{3} / \mathrm{s}$, and the maximum ratio was 40.9 . For purposes of comparison, only peak discharges greater than $200 \mathrm{ft}^{3} / \mathrm{s}$ were considered in this analysis.

Because the timing of precipitation events can sometimes cause the peak discharge from a storm to occur on the day before the majority of the storm runoff occurs, a more useful measure of streamflow flashiness is the ratio between peak discharge and the event-mean discharge. The ranges of event-mean discharges for the peak-discharge events used to describe streamflow flashiness were $51 \mathrm{ft}^{3} / \mathrm{s}$ to $135 \mathrm{ft}^{3} / \mathrm{s}$ during the pre-restoration period, and $40 \mathrm{ft}^{3} / \mathrm{s}$ to $134 \mathrm{ft}^{3} / \mathrm{s}$ during the post-restoration period. The maximum ratios of peak discharge and event-mean discharge are 11.6 (June 12, 2003) and 10.5 (June 25, 2006) for the pre- and post-restoration periods, respectively.

The relations between instantaneous peak discharges and both the daily-mean and event-mean based ratios described here are shown in figure 9. Comparison of the respective coefficients of determination, $\mathrm{R}^{2}$, shows that the relations between instantaneous peak discharge and its ratio with the event-mean discharge is more linear than that with the daily-mean discharge ratio in both the pre-restoration and post-restoration periods. It is also evident that neither relation appears to have changed considerably during the full study period, so stream flashiness in Minebank Run was not affected by the physical restoration of the stream channel.

\section{Time of Concentration}

In Doheny and others (2006), times of concentration were calculated for 18 selected precipitation events that occurred within the pre-restoration monitoring period between November 2001 and July 2004, using precipitation data from the recording precipitation gage near the study reach and USGS streamgage 0158397967, Minebank Run near Glen Arm, Maryland. The hydrologic response characterized by the time of concentration for these events varied from 5 minutes to 90 minutes, and included events displaying a range of durations and intensities. 
The data that were presented in Doheny and others (2006) describing the 18 selected events are included in table 6 . The table also includes data from 20 additional post-restoration events that occurred in the Minebank Run watershed between March 2005 and July 2008, calculated using the same data sources as those used in the pre-restoration period, as well as times of concentration for the same events in the West Branch Herring Run watershed. These values were calculated using data from the same recording precipitation gage and USGS streamgage 01585200, West Branch Herring Run at Idlewylde, Maryland. The West Branch Herring Run watershed monitored by this streamgage is of similar size $\left(2.13 \mathrm{mi}^{2}\right)$ and shape to the monitored section of Minebank Run. The two watersheds are adjacent, sharing a boundary at their respective headwaters (fig. 10). Unlike Minebank Run, the West Branch Herring Run stream channel had not undergone any restoration work during the study period, and is characterized by trapezoidal concrete lining over much of its monitored length. This condition provides a contrast to the channel conditions seen in Minebank Run, both before and after restoration, and can also be used to identify any effects on watershed response relating to environmental conditions rather than restoration activities.

A plot of maximum rainfall intensity against time of concentration for Minebank Run and West Branch Herring Run for selected pre-and post-restoration storm events is shown in figure 11. In almost all cases, the times of concentration for West Branch Herring Run are less than those for Minebank Run. The times of concentration for West Branch Herring Run also fall within a narrower range than those for Minebank Run. This is not unexpected given that the smooth-lined, concrete channel characteristic of the monitored section of West Branch Herring Run should be a more efficient runoff conduit than the unlined channel of Minebank Run. On the basis of this analysis, the ranges of the times of concentration for both sites can be considered comparable for both the pre- and postrestoration monitoring periods.
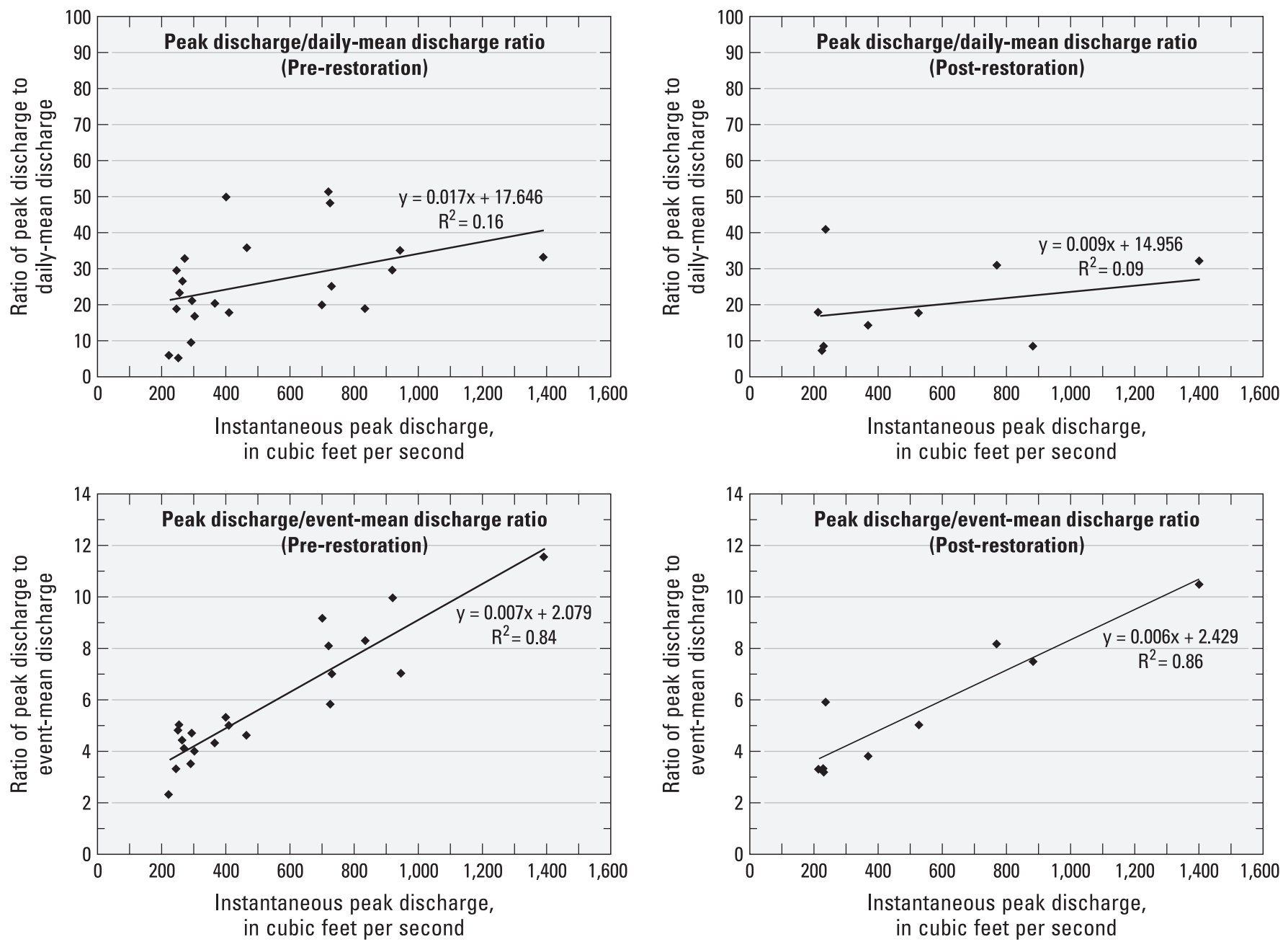

Figure 9. Relations between instantaneous peak discharge and ratios of daily-mean and event-mean discharges, pre- and postrestoration, at station 0158397967, Minebank Run near Glen Arm, Maryland. 
Table 6. Time of concentration for 38 selected storms in the Minebank Run and West Branch Herring Run watersheds, water years 2002 through 2008 (modified from Doheny and others, 2006).

[EST, Eastern Standard Time; hrs, hours; in., inches; in/h, inches per hour; min, minutes]

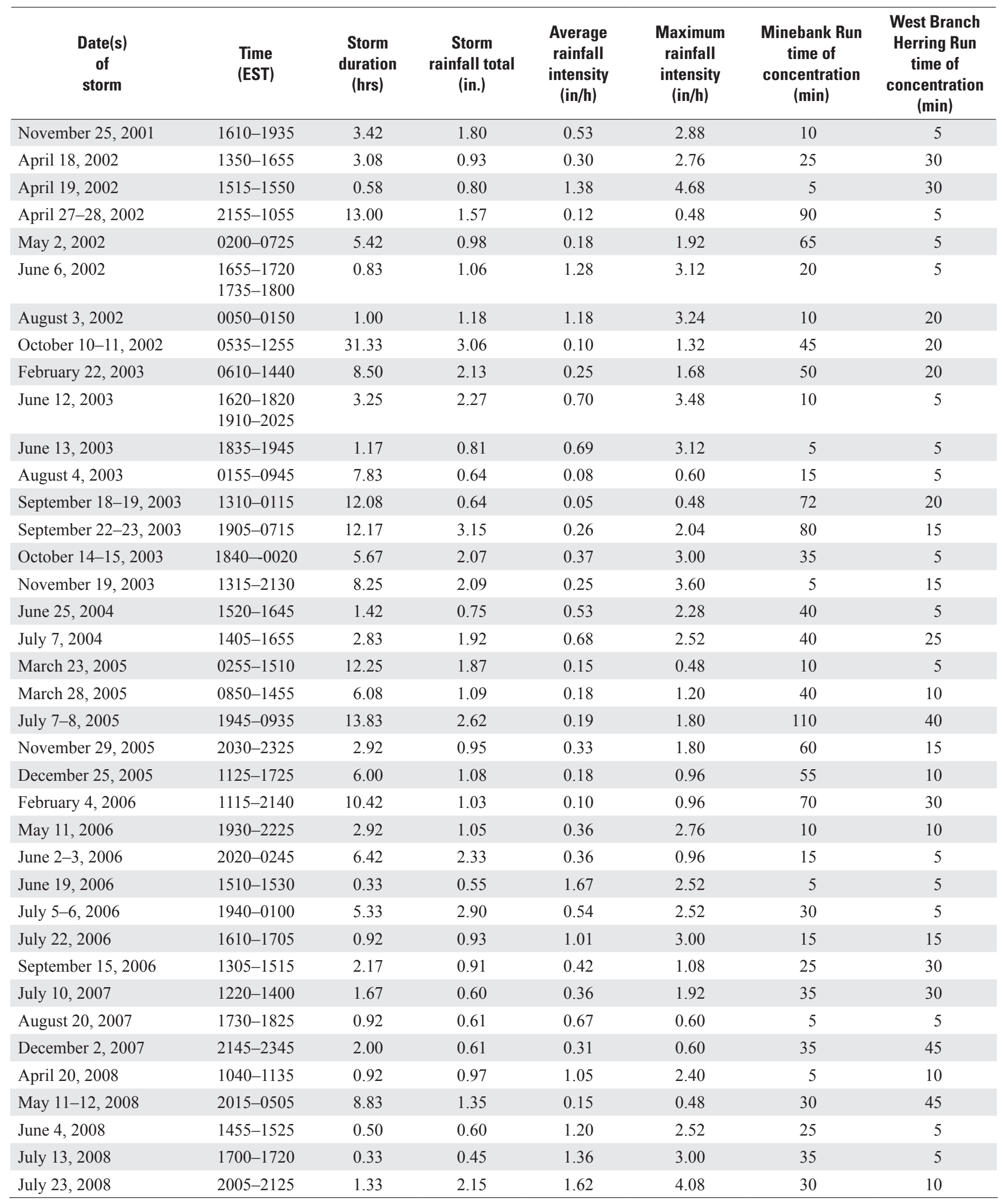




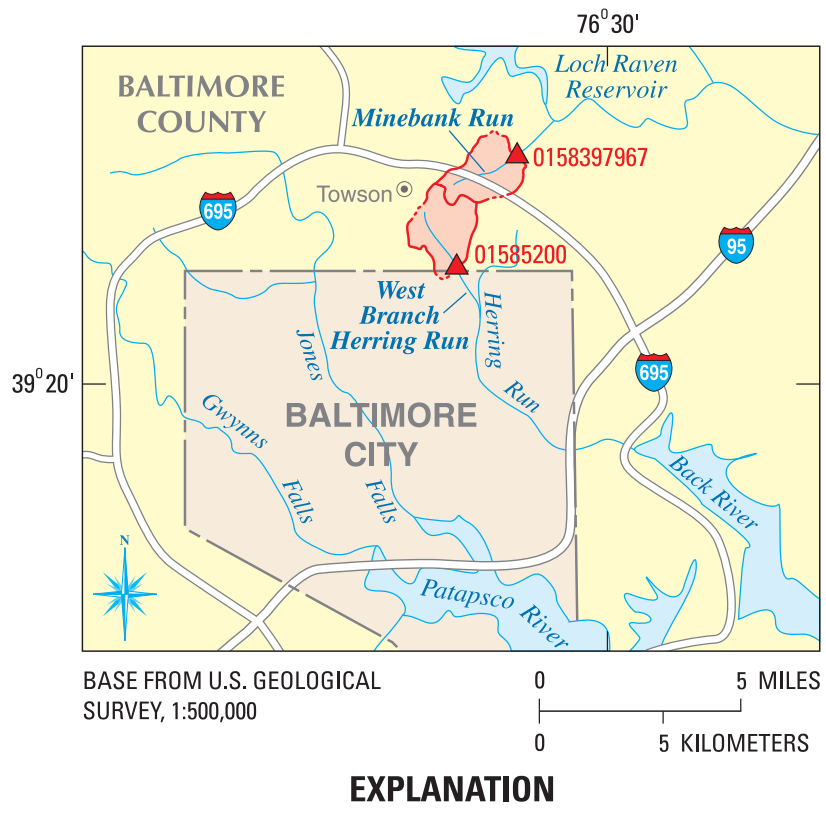

${ }_{0158397967} \triangle$ Continuous-record streamgage and identification number

Figure 10. Locations and contributing areas of watersheds draining to station 01585200, West Branch Herring Run at Idlewylde, Maryland and station 0158397967, Minebank Run near Glen Arm, Maryland.

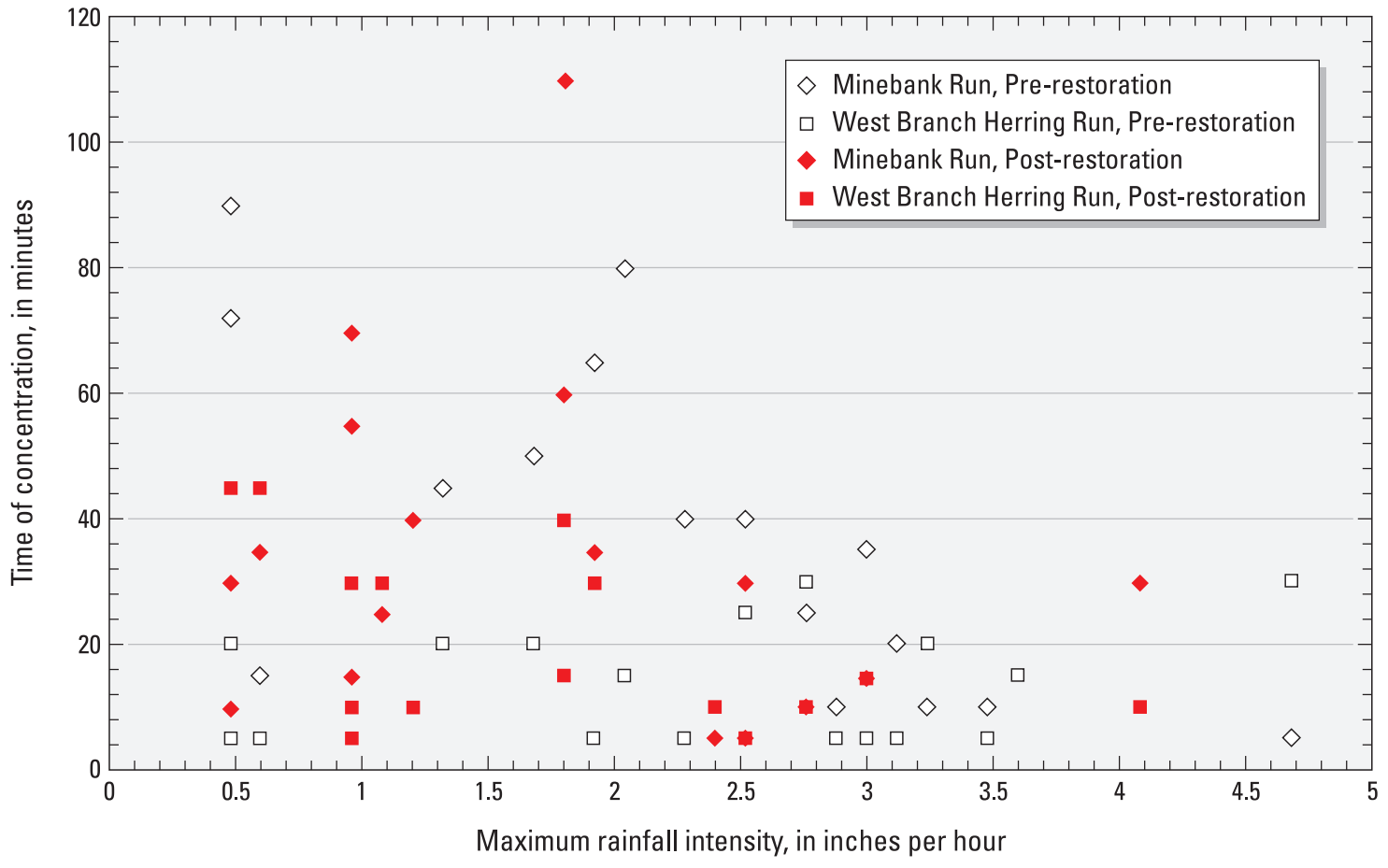

Figure 11. Maximum rainfall intensity against time of concentration for Minebank Run and West Branch Herring Run for selected pre- and post-restoration storm events, water years 2002 through 2008. 


\section{Flood Frequency}

Estimated flood-frequency characteristics for Minebank Run at USGS streamgage 0158397967, Minebank Run near Glen Arm, Maryland were presented in Doheny and others (2006), based on discharge data collected during water years 1997 through 2004 (Interagency Advisory Committee on Water Data, 1982). The streamgage began operation in water year 2002, so the amount of data from the station that can be used in this analysis ( 7 years) is relatively limited. In Doheny and others (2006), the authors augmented the peak-discharge data at the subject site with information from another streamgage further downstream on Minebank Run (station 01583980, Minebank Run at Loch Raven, Maryland), and compared the estimates with those from a streamgage in a less-developed watershed of similar size and slope in Baltimore County (station 01583000, Slade Run near Glyndon, Maryland). Data from the streamgage on Minebank Run now includes information from water years 2005 through 2008 in the post-restoration monitoring period. Using the additional data, a different approach has been used to revise the estimated flood-frequency characteristics for the study reach.

For this approach, peak-discharge data from the streamgage on West Branch Herring Run at Idlewylde, Maryland was used in conjunction with data from the study reach at Minebank Run to provide more confidence in the flood-frequency estimates. The linear relation between logtransformed post-restoration (water years 2005 through 2008) annual-peak discharges at Minebank Run and coincident peaks at West Branch Herring Run is shown in figure 12. The relation is very strong, with an $\mathrm{R}^{2}$ of 0.98 . Although there are only four data points in the analysis, it provides confidence that the relation between peaks at the two sites can be used to extrapolate information from West Branch Herring Run to improve understanding of the flood-frequency characteristics at Minebank Run based on a considerably longer peak flow record. This goal was accomplished by estimating the floodfrequency characteristics at West Branch Herring Run using the full dataset from that site (water years 1958 to 1987, and 1997 to 2008), and normalizing those estimates to Minebank Run based on the average ratio of the four coincident peaks plotted in figure 12. On average, the peak discharge at Minebank Run was found to be about 76 percent as large as the corresponding peaks from West Branch Herring Run. The resulting normalized, long-term flood-frequency estimates for Minebank Run are shown in table 7, along with the original estimates from Doheny and others (2006).

The normalized, long-term flood-frequency estimates for Minebank Run predict considerably smaller discharges for all intervals of annual exceedance probability (table 7). This indicates that the largest peak flows that occurred in the Minebank Run watershed during the monitoring period could represent events of lower probability when compared to the considerably longer peak-flow record in the West Branch Herring Run watershed.

\section{Rainfall-Runoff Relations}

Doheny and others (2006) quantified rainfall-runoff relations by listing the percentage of rainfall that was conveyed as runoff for 18 selected precipitation events that occurred between November 2001 and July 2004 as part of the prerestoration monitoring period. Percentages ranged from 11.8 to 60.0 for the selected events, with an average of 29.7 percent. The wide range of percentages was thought to be caused by the range of precipitation and soil moisture conditions during the period, which included drought in 2002, followed by 2 years of above-average precipitation.

Information on an additional 23 post-restoration precipitation events that occurred between March 2005 and July 2008 add to the data presented by Doheny and others (2006) and is shown in table 8. The percentage of rainfall that is conveyed as runoff in the post-restoration monitoring period ranges from 9.8 to 44.4 , with an average of 19.4 percent. Although this period is not considered to have been particularly dry from an annual precipitation standpoint, it is characterized by long periods of little or no rainfall punctuated by a handful of large precipitation events. This may explain why the percentages are considerably lower than the average from the pre-restoration period.

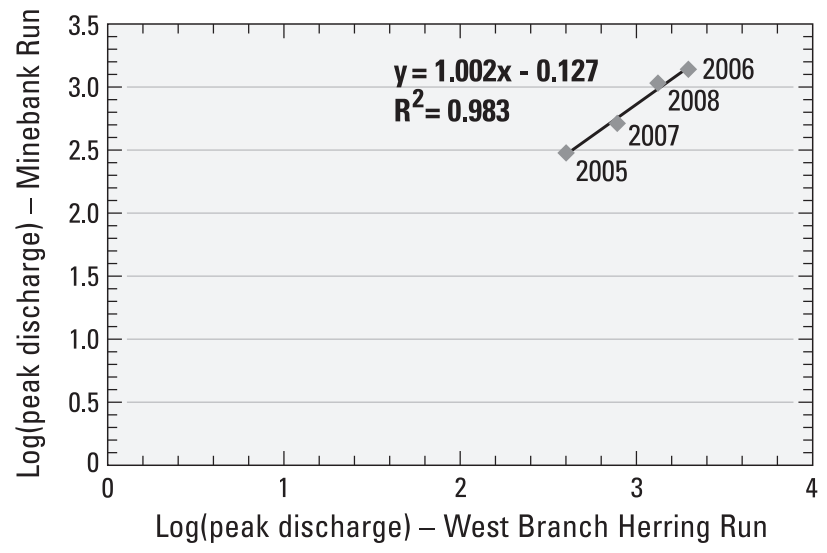

Figure 12. Linear relation between log-transformed annual peak discharges at Minebank Run and coincident peaks at West Branch Herring Run. 


\section{Comparison of Pre- and Post- Restoration Geomorphic Characteristics}

Geomorphic data collected during water years 2002 through 2008 were used to track changes occurring over time and compare pre-restoration and post-restoration geomorphic characteristics in the Minebank Run study reach (Doheny and others, 2007). Geomorphic characteristics that were tracked over time and compared included (1) longitudinal profiles of the channel bed and water surface; (2) changes in crosssection geometry; (3) hydraulic-geometry relations between cross-sectional area, mean channel depth, channel width, and mean velocity and discharge; (4) grain-size analyses of the channel bed; (5) net changes in the elevation of the channel bed at selected locations over time; (6) analyses of boundary shear stress based on cross-section geometry and water-surface slope in the vicinity of the streamgage; and (7) net changes in estimated sediment volume in the study reach.

\section{Longitudinal Profiles}

Longitudinal profiles of the channel bed, water surface, and other channel features were developed for the Minebank Run study reach on the basis of yearly field surveys that were conducted between April 2002 and April 2008. Slopes of the channel bed and water surface were determined by use of simple linear regression. Percentages of riffles, pools, and runs were determined for each profile based on the stream length of each feature relative to the length of the surveyed reach. The profiles also were analyzed to determine differences in the distribution and location of riffles, pools, and runs throughout the study reach over time (Doheny and others, 2007). An aerial view of the study reach used for the longitudinal surveys is shown in figure 13 (Baltimore County Department of Environmental Protection and Resource Management, 2000). An example plot of the longitudinal profile that was developed from the March 30, 2005 survey is shown in figure 14.

Pre-restoration surveys conducted between 2002 and 2004 indicated a distinct and extensive series of point bar and terrace features in the main channel along the study reach.

Table 7. Comparison of flood-frequency analyses for Minebank Run, based on station data from 1997-2004 and normalized from longterm estimates at West Branch Herring Run (modified from Doheny and others, 2006).

[yrs, years; $\mathrm{ft}^{3} / \mathrm{s}$, cubic feet per second]

\begin{tabular}{|c|c|c|c|}
\hline $\begin{array}{c}\text { Annual } \\
\text { exceedance } \\
\text { probability }\end{array}$ & $\begin{array}{c}\text { Recurrence } \\
\text { interval } \\
\text { (yrs) }\end{array}$ & $\begin{array}{c}\text { Discharge for } \\
\text { U.S. Geological Survey station } \\
\text { number 0158397967, Minebank } \\
\text { Run near Glen Arm, Maryland } \\
\text { (1997-2004) } \\
\left(\mathrm{ft}^{3} / \mathrm{s}\right)\end{array}$ & $\begin{array}{c}\text { Discharge for U.S. Geological Survey station } \\
\text { number 0158397967, Minebank Run near Glen } \\
\text { Arm, Maryland, normalized based on estimates } \\
\text { from station 01585200, West Branch Herring Run } \\
\text { at Idlewylde, Maryland (1958-1987, 1997-2008) } \\
\text { (ft/s) }\end{array}$ \\
\hline 0.995 & 1.005 & 252.2 & 109.4 \\
\hline 0.900 & 1.11 & 472.1 & 230.2 \\
\hline 0.800 & 1.25 & 589.4 & 301.0 \\
\hline 0.500 & 2 & 912.7 & 513.8 \\
\hline 0.200 & 5 & $1,437.0$ & 903.3 \\
\hline 0.010 & 100 & $3,339.0$ & $2,630.0$ \\
\hline 0.005 & 200 & $3,867.0$ & $3,176.0$ \\
\hline 0.002 & 500 & $4,631.0$ & $4,008.0$ \\
\hline
\end{tabular}

${ }^{1}$ Peak-discharge record for flood-frequency analysis estimated using drainage area ratios from U.S. Geological Survey station 01583980, Minebank Run at Loch Raven, Maryland for water years 1997 through 2001. 
Table 8. Runoff amounts and percentages for 41 selected storm events at U.S. Geological Survey station 0158397967, Minebank Run near Glen Arm, Maryland, water years 2002 through 2008.

[hrs, hours; in., inches; $\mathrm{ft}^{3} / \mathrm{s}$, cubic feet per second; $\mathrm{ft}^{3}$, cubic feet]

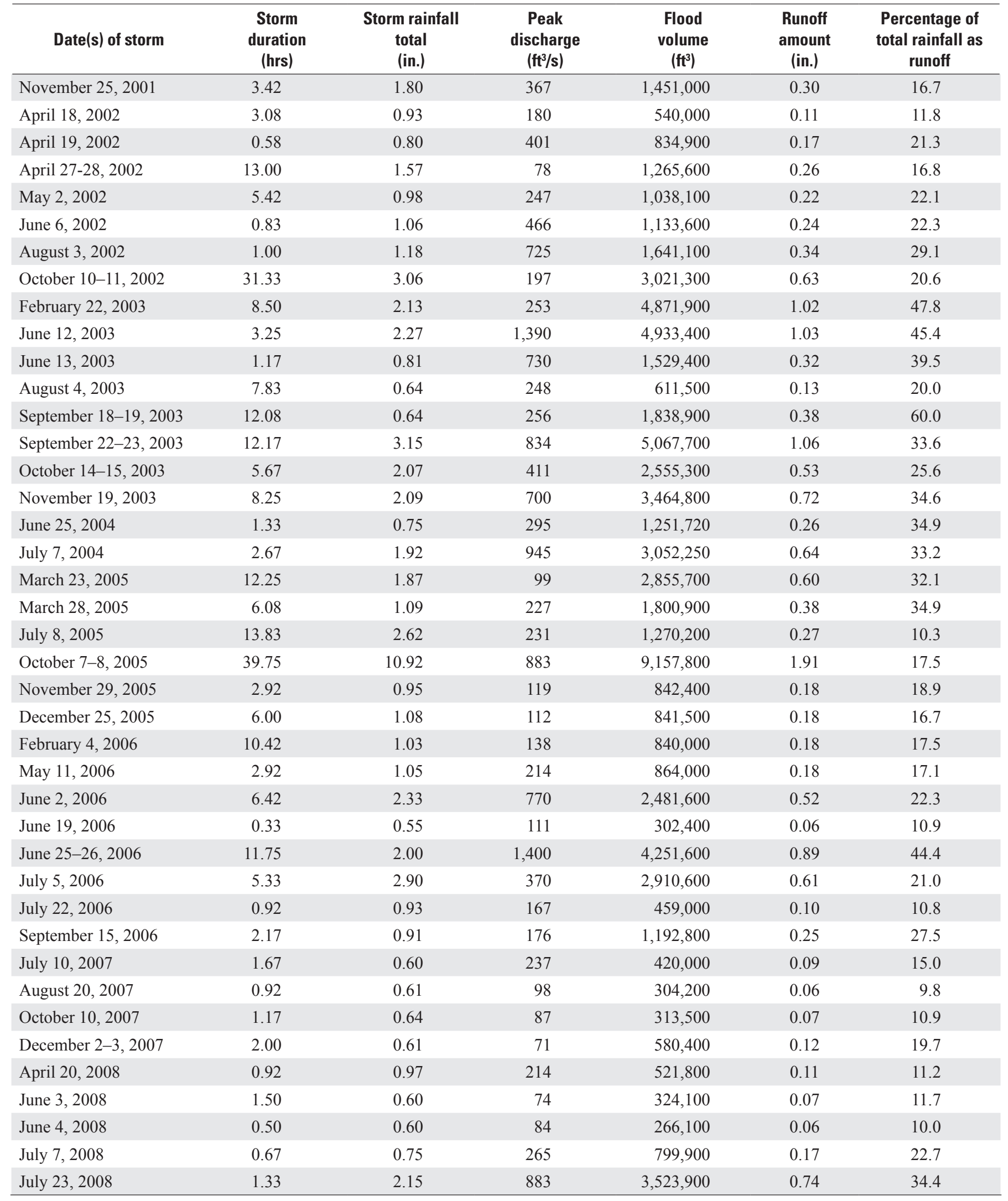




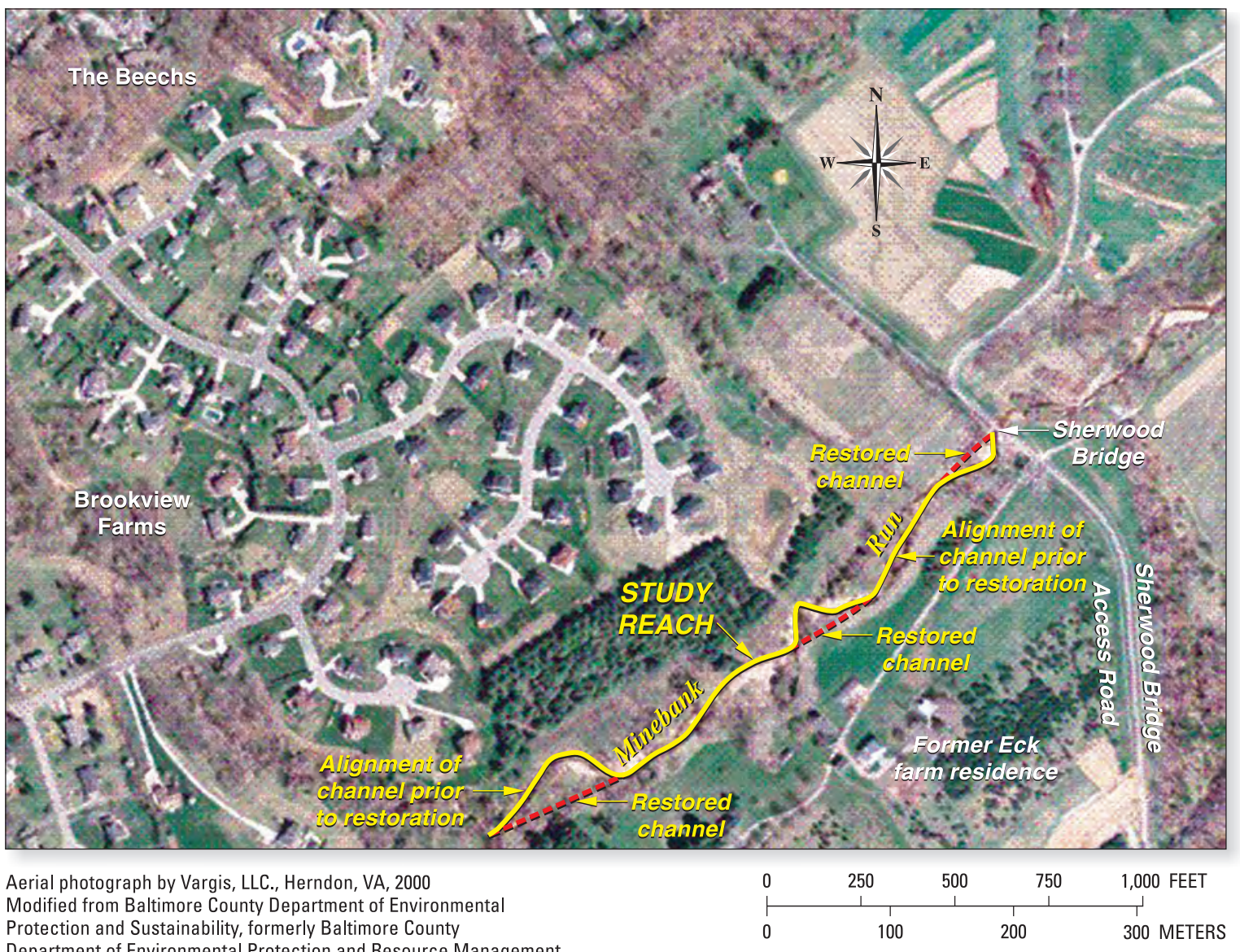

Protection and Sustainability, formerly Baltimore County

Department of Environmental Protection and Resource Management

Figure 13. Aerial photograph showing Minebank Run study reach in Cromwell Valley Park prior to channel restoration.

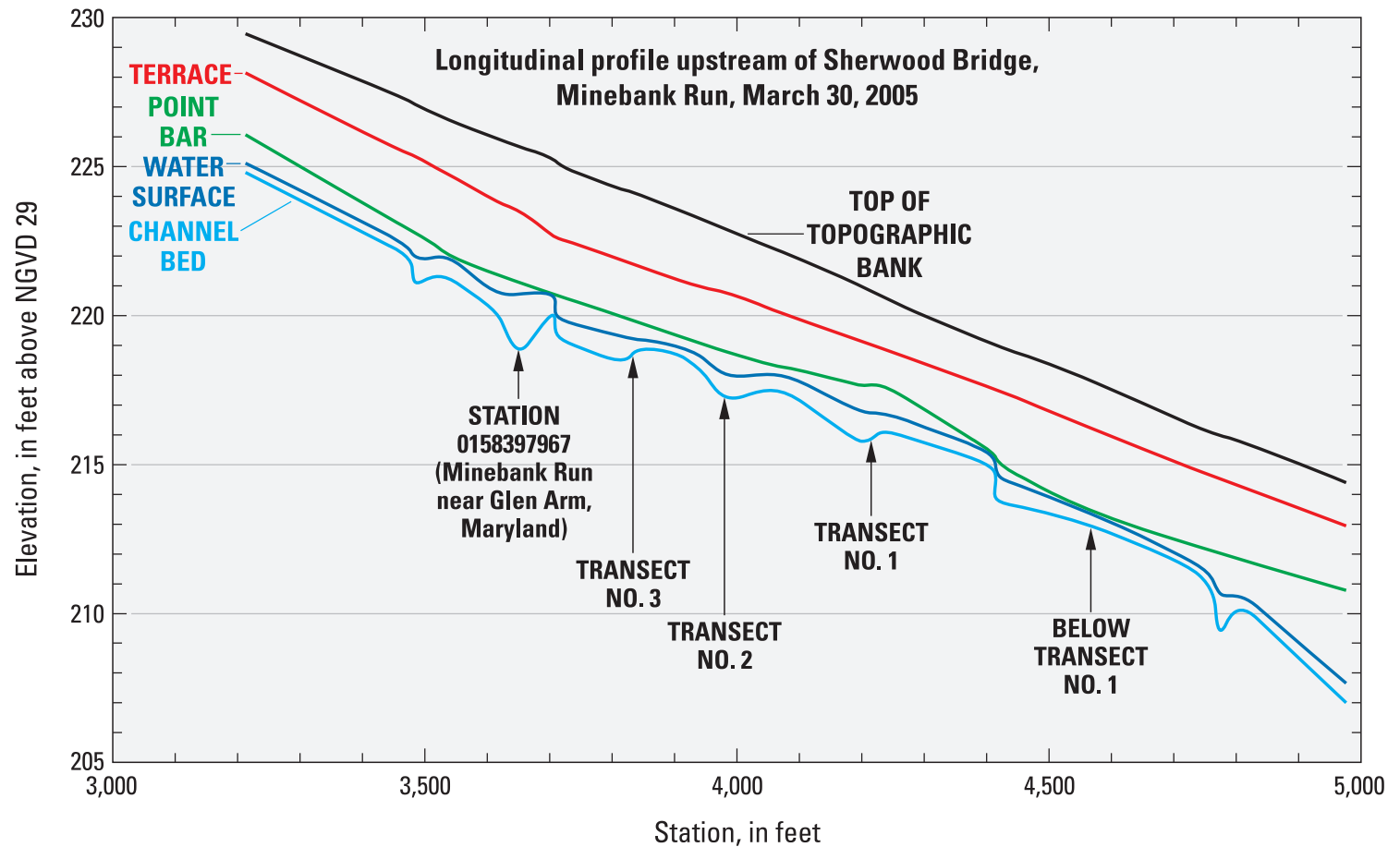

Figure 14. Longitudinal profile of channel features in the Minebank Run study reach from field survey conducted on March 30, 2005. 
The presence of these features indicates that the channel bed had degraded and widened over time, and abandoned its flood plain at least twice due to degradation in the pre-restoration state (Doheny and others, 2007). Post-restoration surveys also indicated evidence of the point bar and terrace features throughout the study reach (fig. 14), as they were either left in place in areas of the study reach that were undisturbed by the restoration work, or implemented into the restoration design for re-establishing a flood plain for the stream channel.

Slopes were computed for the channel bed and water surface for each of the seven longitudinal profiles surveyed between April 2002 and April 2008. The results are shown in table 9.

Slopes for the channel bed and water surface were approximately 1 percent or slightly less as shown in table 9 . The survey in March 2005 is representative of the post-construction condition just after the stream restoration work was completed in February 2005. Whereas the restored channel bed and water surface slopes are slightly less than those found prior to restoration, these slopes have been maintained at almost the same percentage that was determined just after completion of the restoration work in 2005, despite six major storm events that hit the watershed during water years 2006 through 2008.

Data from the longitudinal profile surveys also were analyzed to determine the percentages of riffles, pools, and runs in the study reach and whether these percentages and distribution remain consistent over time. The percentages of riffles, pools, and runs in the Minebank Run study reach that were determined from the longitudinal-profile surveys between 2002 and 2008 are shown in table 10. The distribution and percentages of riffles, pools, and runs that were determined from the longitudinal-profile surveys between 2002 and 2008 are shown in figure 15.

Based on the pre-restoration surveys that were conducted prior to 2005 , noticeable changes were evident in the percentages and distribution of riffles, pools, and runs in the study reach (Doheny and others, 2007). The changes in percentages of riffles, pools, and runs between 2002 and 2004 indicated that, on average, different sections of the stream channel were going through alternating periods of scour and fill over time (Doheny and others, 2007). Increasing riffle and run percentages with corresponding decreases in pool percentages between 2002 and 2003 indicated that sediment storage was increasing in the study reach during this period of time. Increasing pool percentages with a corresponding decrease in run percentages between 2003 and 2004 indicated that sediment storage was decreasing in the study reach during this period of time (Doheny and others, 2007).

When the stream restoration was completed in 2005, the longitudinal profile from that year indicated that the stream channel was considerably more riffle-dominated with lesser percentages of pools. The longitudinal profiles from 2006 through 2008 showed a considerable reduction in riffle percentages from riffle percentages found in 2005, with a greater balance of pool and run percentages in the study reach.
Table 9. Slopes of the channel bed and water surface in the Minebank Run study reach from longitudinal profile surveys, 2002-08 (modified from Doheny and others, 2007).

\begin{tabular}{ccc}
\hline $\begin{array}{c}\text { Date of } \\
\text { survey }\end{array}$ & $\begin{array}{c}\text { Channel } \\
\text { bed }\end{array}$ & $\begin{array}{c}\text { Water } \\
\text { surface }\end{array}$ \\
\hline April 16, 2002 & 0.0101 & 0.0100 \\
\hline March 31-April 1, 2003 & 0.0093 & 0.0092 \\
\hline April 23, 2004 & 0.0095 & 0.0095 \\
\hline March 30, 2005 & 0.0088 & 0.0088 \\
\hline March 23-24, 2006 & 0.0087 & 0.0090 \\
\hline April 18, 2007 & 0.0088 & 0.0088 \\
\hline April 10-11, 2008 & 0.0091 & 0.0092 \\
\hline
\end{tabular}

Table 10. Percentages of riffles, pools, and runs in the Minebank Run study reach from longitudinal-profile surveys, 2002-08 (modified from Doheny and others, 2007).

$[\%$, percent]

\begin{tabular}{|cccc}
\hline $\begin{array}{c}\text { Date of } \\
\text { survey }\end{array}$ & $\begin{array}{c}\text { Riffle } \\
(\%)\end{array}$ & $\begin{array}{c}\text { Pool } \\
(\mathbf{\%})\end{array}$ & $\begin{array}{c}\text { Run } \\
(\%)\end{array}$ \\
\hline April 16, 2002 & 42.2 & 42.3 & 15.5 \\
\hline March 31-April 1, 2003 & 52.2 & 27.5 & 20.3 \\
\hline April 23, 2004 & 52.4 & 39.9 & 7.7 \\
\hline March 30, 2005 & 73.8 & 12.3 & 13.9 \\
\hline March 23-24, 2006 & 38.2 & 31.9 & 29.9 \\
\hline April 18, 2007 & 42.1 & 22.0 & 35.8 \\
\hline April 10-11, 2008 & 39.1 & 38.5 & 22.4 \\
\hline
\end{tabular}

Between 2006 and 2008, riffle percentages ranged from 38.2 to 42.1 percent. These percentages are very similar in magnitude to the percentage of 42.2 percent that was determined based on the 2002 survey. Pool percentages continued to show an alternating pattern of increases and decreases between 2006 and 2008, which indicates a continuing pattern of scour and fill in the study reach over time. Percentages of runs were larger based on the 2006-08 surveys than in 2005, immediately after completion of the stream restoration project. Run percentages also showed an alternating pattern of increases and decreases each year, but opposite of the pattern shown in pool percentages. This indicates that, on average, the channel was scouring and storing less sediment between 2005 and 2006. The channel was filling and storing more sediment between 2006 and 2007, and scouring again between 2007 and 2008.

Comparison of the profiles over time indicated considerable differences in the distribution and location of riffles, pools, and runs in the study reach each year (Doheny and others, 2007). This pattern is evident in both the pre- and post-restoration monitoring periods (fig. 15). In both the pre-restoration and post-restoration monitoring periods, the analyses indicated that, on average, the stream is maintaining 


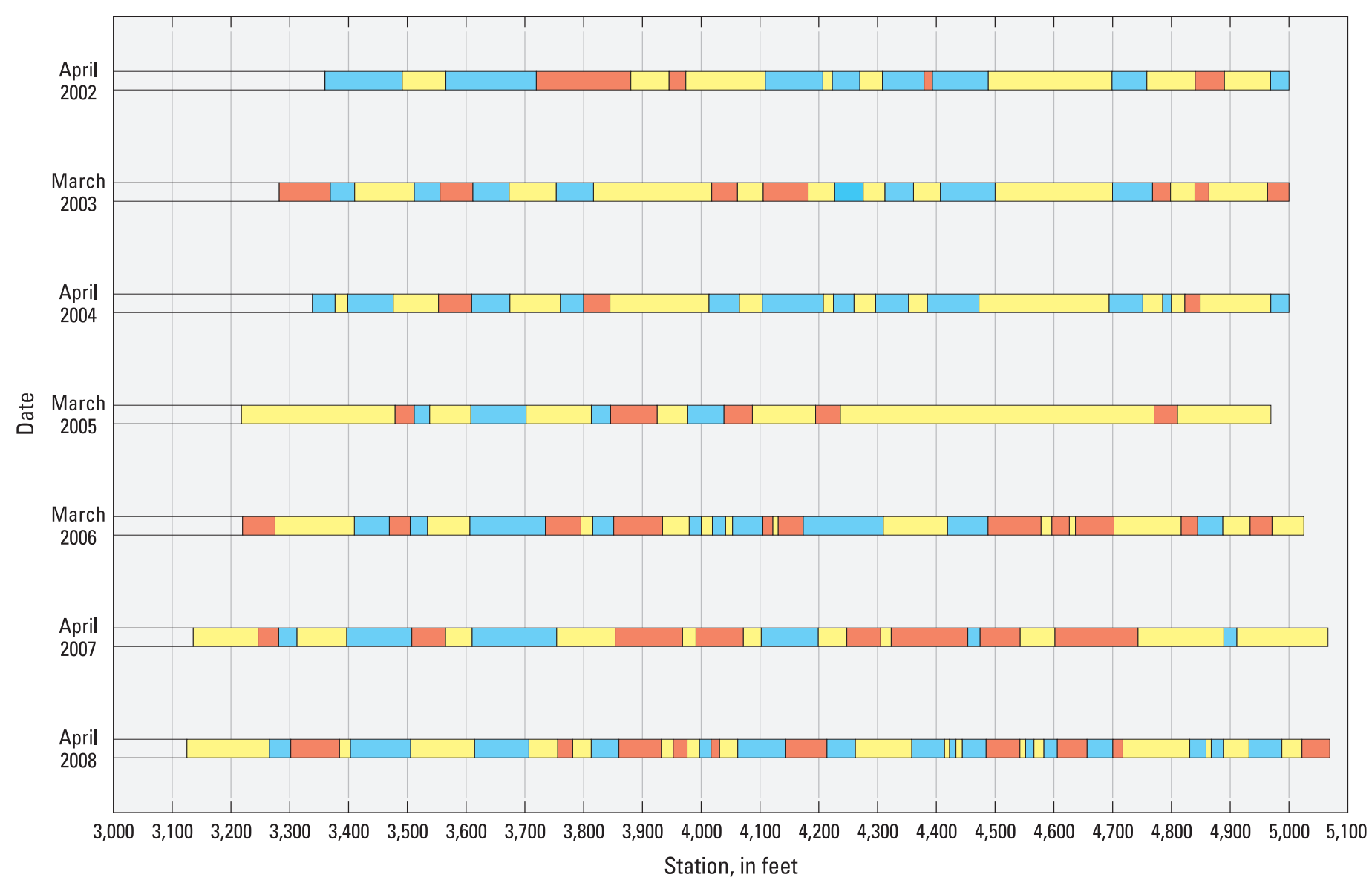

\section{EXPLANATION}
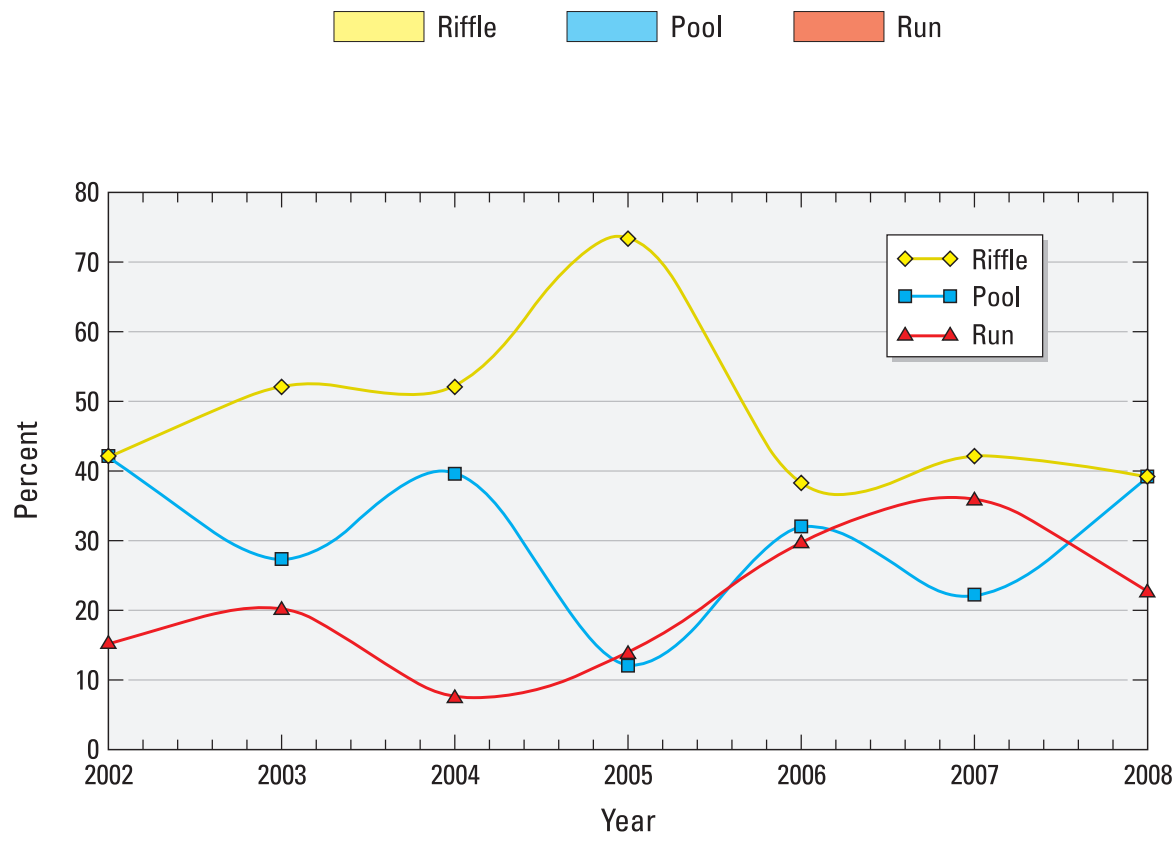

Figure 15. Comparison of riffle, pool, and run distribution and percentages in the Minebank Run study reach before and after channel restoration, 2002 through 2008. 
the overall slope of the channel bed and water surface in the study reach, despite considerable changes in the percentages of riffles, pools, and runs, and changes in the distribution and location of these features within the reach.

\section{Cross-Section Geometry}

Pre-restoration channel geometry at the nine permanent cross sections was determined on the basis of field surveys conducted in December 2002, June-July 2003, and in January-February 2004 (Doheny and others, 2007). Postrestoration channel geometry at the nine permanent cross sections was determined on the basis of field surveys conducted in April 2005, November-December 2005, September 2006, August 2007, and April 2008. Each cross section was plotted for the three pre-restoration surveys and the five postrestoration surveys to determine the changes in bed elevation and channel alignment over time. Cross-sectional area, wetted perimeter, hydraulic radius, channel width, and mean channel depth were determined for each cross section at a range of water-surface elevations, and compared to document changes that occurred between field surveys (Doheny and others, 2007). Plots of the nine permanent cross sections and crosssection geometry prior to restoration were previously published in Doheny and others (2007).

On the basis of geomorphic conditions that were interpreted from changes in the cross sections during the pre-restoration monitoring period, cross sections $\mathrm{Bb}$ and Ee appeared to be primary areas for sediment storage within the study reach. Cross section Ee appeared to store large volumes of sediment for short periods of time and was vertically and laterally unstable. Cross section $\mathrm{Bb}$ showed net aggradation of the channel bed over time with small amounts of lateral erosion. Cross sections $\mathrm{Aa}, \mathrm{Cc}$, and $\mathrm{Hh}$ also showed indications of temporary sediment storage and removal over time. Cross sections Aa, Dd, Ee, Ff, and Ii appeared to be the most unstable cross sections in the study reach, due to either considerable lateral erosion, erosion of the channel bed, or both. Cross section Gg appeared to be laterally unstable with a lesser degree of vertical instability. On the basis of the locations of cut banks and lateral erosion in the study reach, the stream channel was actively adjusting its meander pattern and trying to increase its sinuosity prior to restoration (Doheny and others, 2007).

Plots of the nine permanent cross sections (Aa-Ii) after restoration are shown in figures 16-24. Cross-section geometry at a range of water-surface elevations was determined at all nine permanent cross-section locations. A comparison of cross-section geometry for cross-section $\mathrm{Hh}$ from the five post-restoration field surveys conducted during 2005 through 2008 is shown in table 11. Post-restoration comparisons for each of the other eight permanent cross sections in the Minebank Run study reach are included in Appendix 1.

A net decrease in cross-sectional area, hydraulic radius, and mean depth over time is evident at cross section Hh (table 11). Channel width and wetted perimeter showed net increases at most elevations over time. The cross-section surveys also indicated alternating increases and decreases in cross-sectional area and mean depth during different periods of time, which could indicate alternating degradation and aggradation of the channel bed resulting from temporary storage and removal of sand and gravel during storm events (Doheny and others, 2007). These changes were generally more variable during 2005-06 and less variable during 2006-08. Even with considerable lateral erosion on the right side of the channel due to erosion of a point bar, the cross-sectional area is still showing a net decrease over time due to considerable aggradation of the bed on the left side of the channel.

These analyses were performed for all permanent cross sections in the Minebank Run study reach, and used to develop an overall assessment of channel geometry changes in the study reach that occurred between April 2005 and April 2008. The results are summarized in table 12 .

At cross section Aa, the relatively small net increases and decreases in cross-sectional area and mean depth with minimal amounts of lateral erosion and thalweg shifting indicate a relatively stable cross section. The periods of alternating increases and decreases in cross-sectional area and mean depth indicate a pattern of storage and removal of sand and gravel at this location during storms, but with more variability in the first 1.0 to 1.5 years after completion of the restored stream channel.

At cross section $\mathrm{Bb}$, the net increases in cross-sectional area and mean depth with minimal amounts of lateral erosion indicate channel incision over time in this section. Cross section $\mathrm{Bb}$ also does not appear to be a primary location for sediment storage, based on the pattern of gradually lower bed elevations over time and no clear pattern of any alternating increases and decreases in cross-sectional area or mean depth.

Cross section Cc showed net increases in cross-sectional area and mean depth at most elevations, with more considerable net increases within the main channel below elevations of $215.50 \mathrm{ft}$. The net increases in cross-sectional area and mean depth in the main channel, along with periods of alternating increases and decreases between surveys, could indicate that sand and gravel could be temporarily stored in this location after certain storm events despite overall degradation during the post-restoration monitoring period.

Cross section Dd showed net increases in cross-sectional area over time at all elevations, and in mean depths at lower elevations. The net increases in cross-sectional area, and in mean depth at lower elevations, along with alternating increases and decreases between surveys indicates that sand and gravel could be temporarily stored in this location after certain storm events despite overall degradation during the post-restoration monitoring period. Increasing elevations on the right overbank indicate that overbank flows may have deposited a $0.10-0.20-\mathrm{ft}$ depth of fine sediment in the overbank area between 2005 and 2008.

Cross section Ee showed net increases in mean channel depth, shifting channel thalweg, and net decreases in channel width. This indicates channel incision in this section, along 


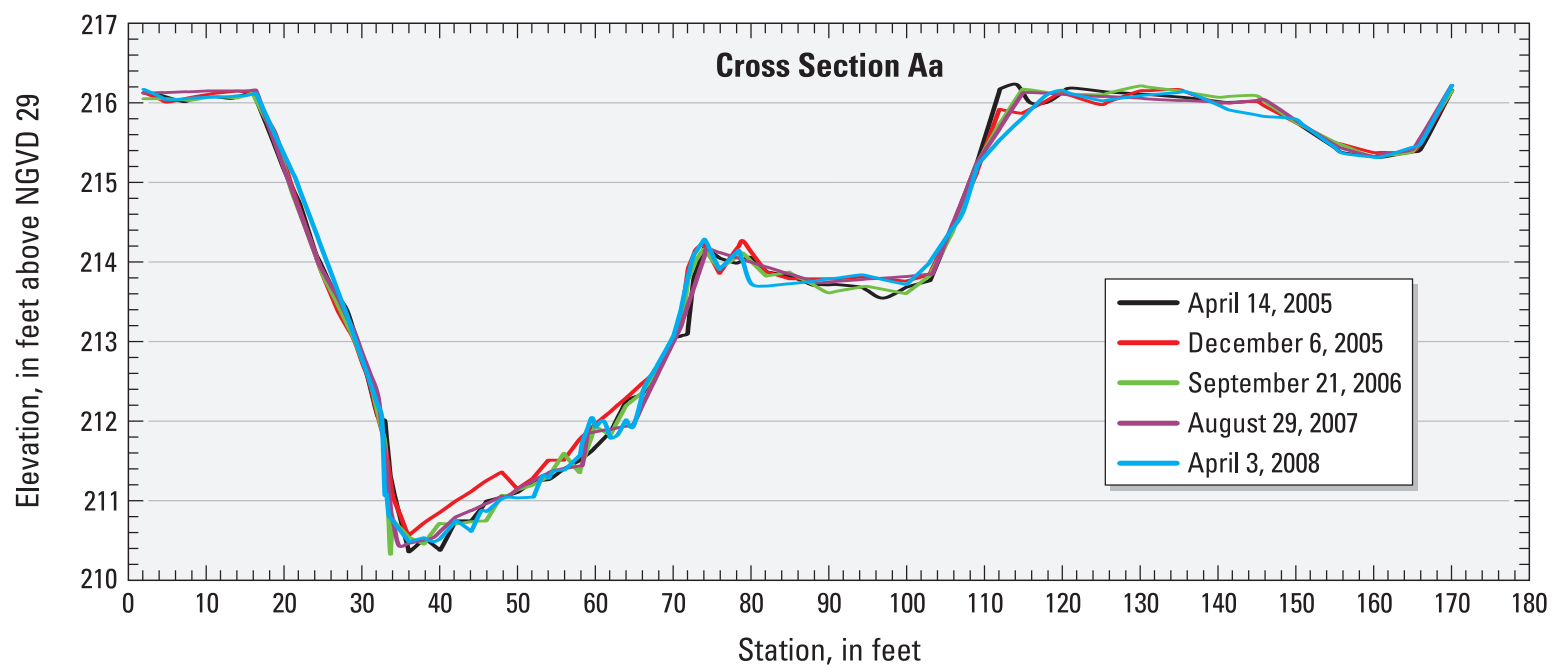

Figure 16. Post-restoration cross-section geometry at permanent cross section Aa, April 2005 through April 2008.

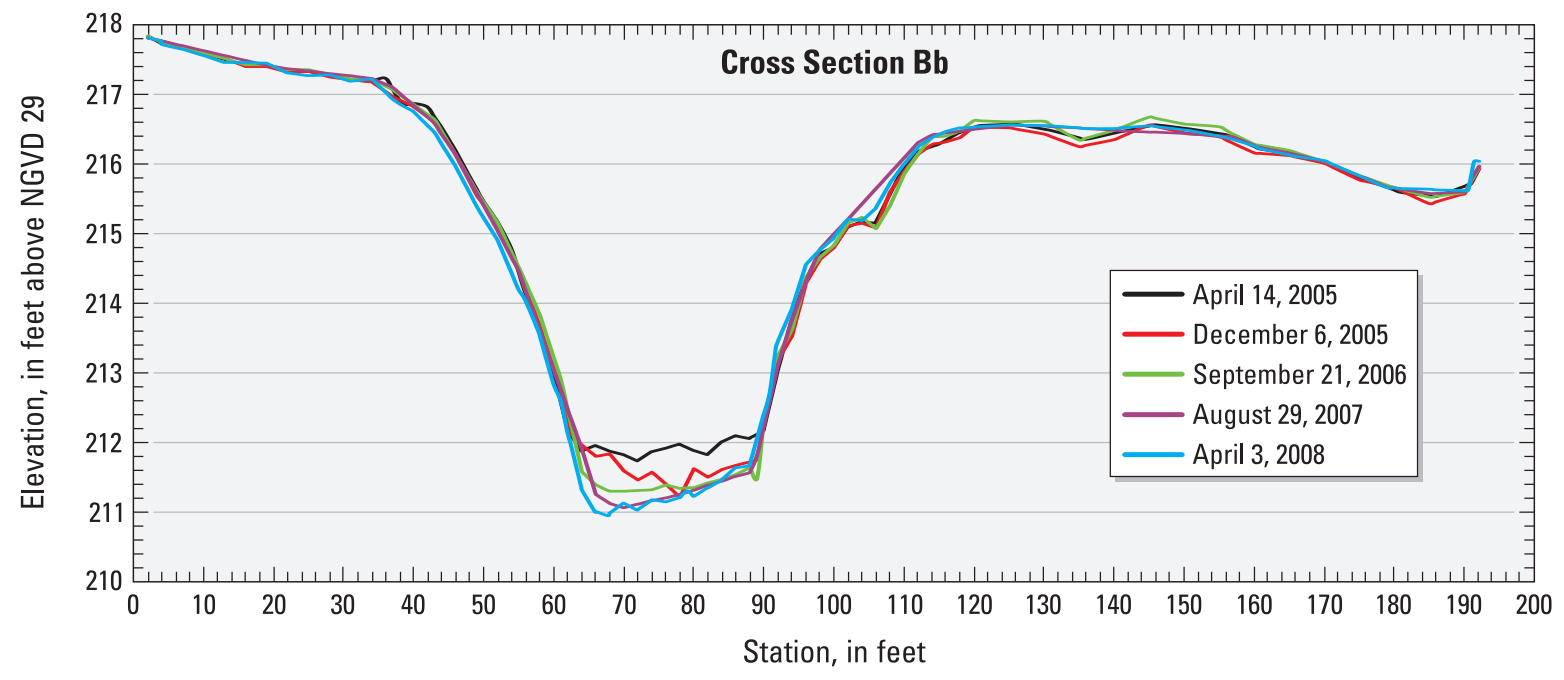

Figure 17. Post-restoration cross-section geometry at permanent cross section Bb, April 2005 through April 2008.

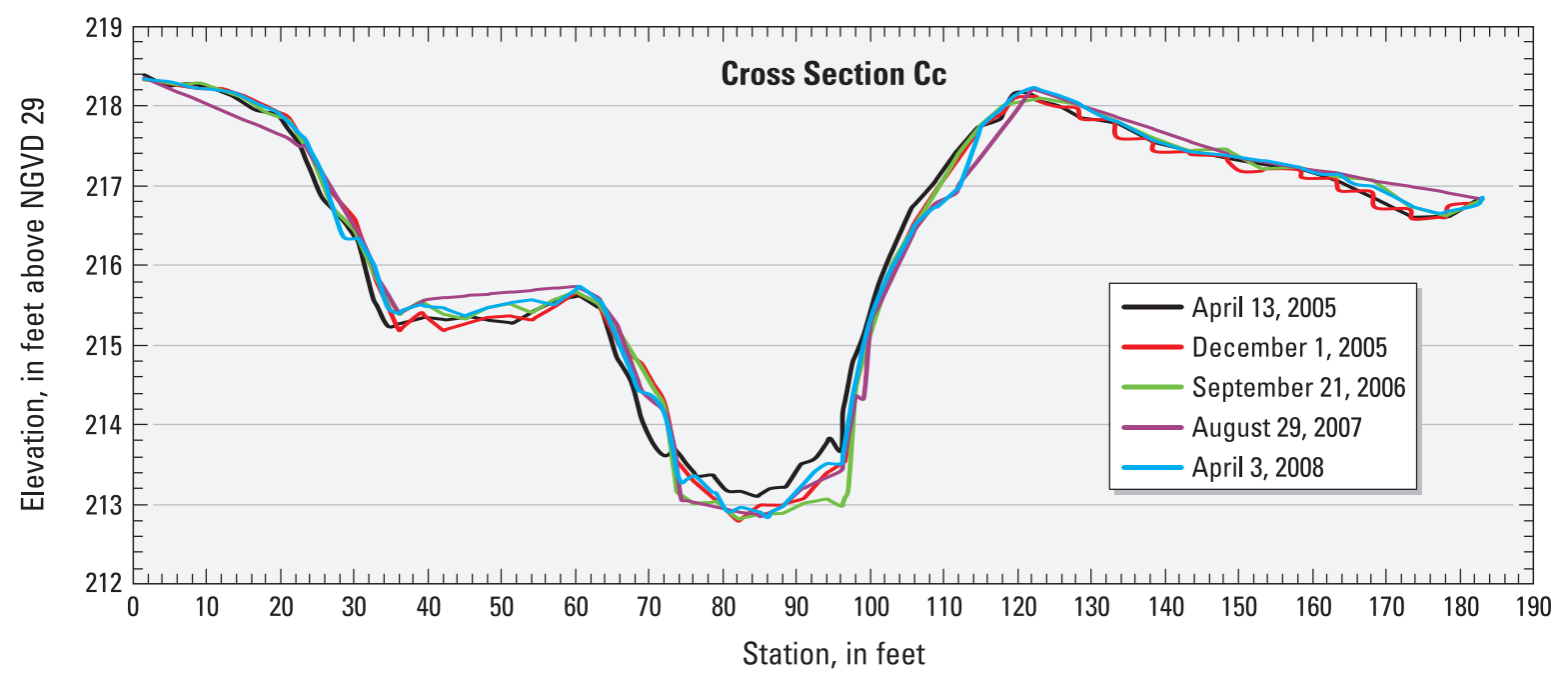

Figure 18. Post-restoration cross-section geometry at permanent cross section Cc, April 2005 through April 2008. 


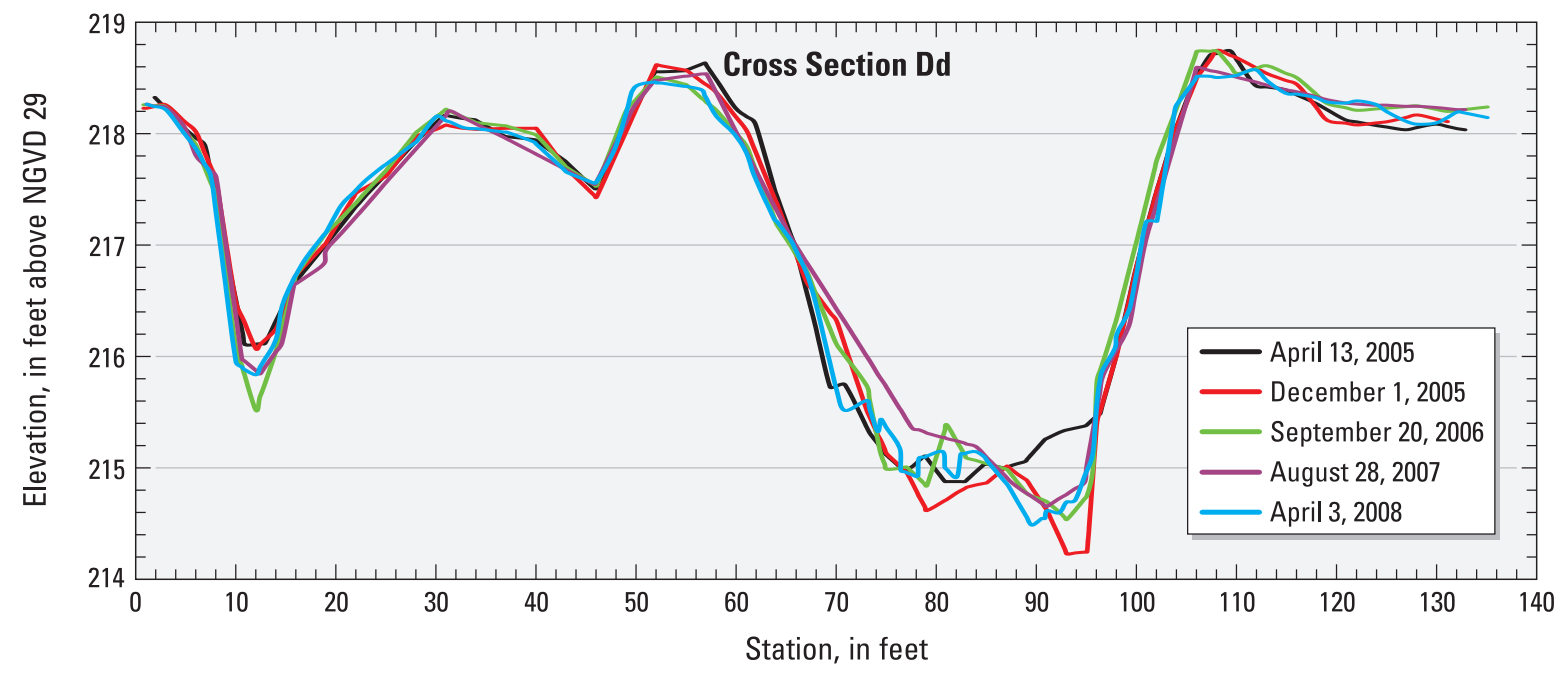

Figure 19. Post-restoration cross-section geometry at permanent cross section Dd, April 2005 through April 2008.

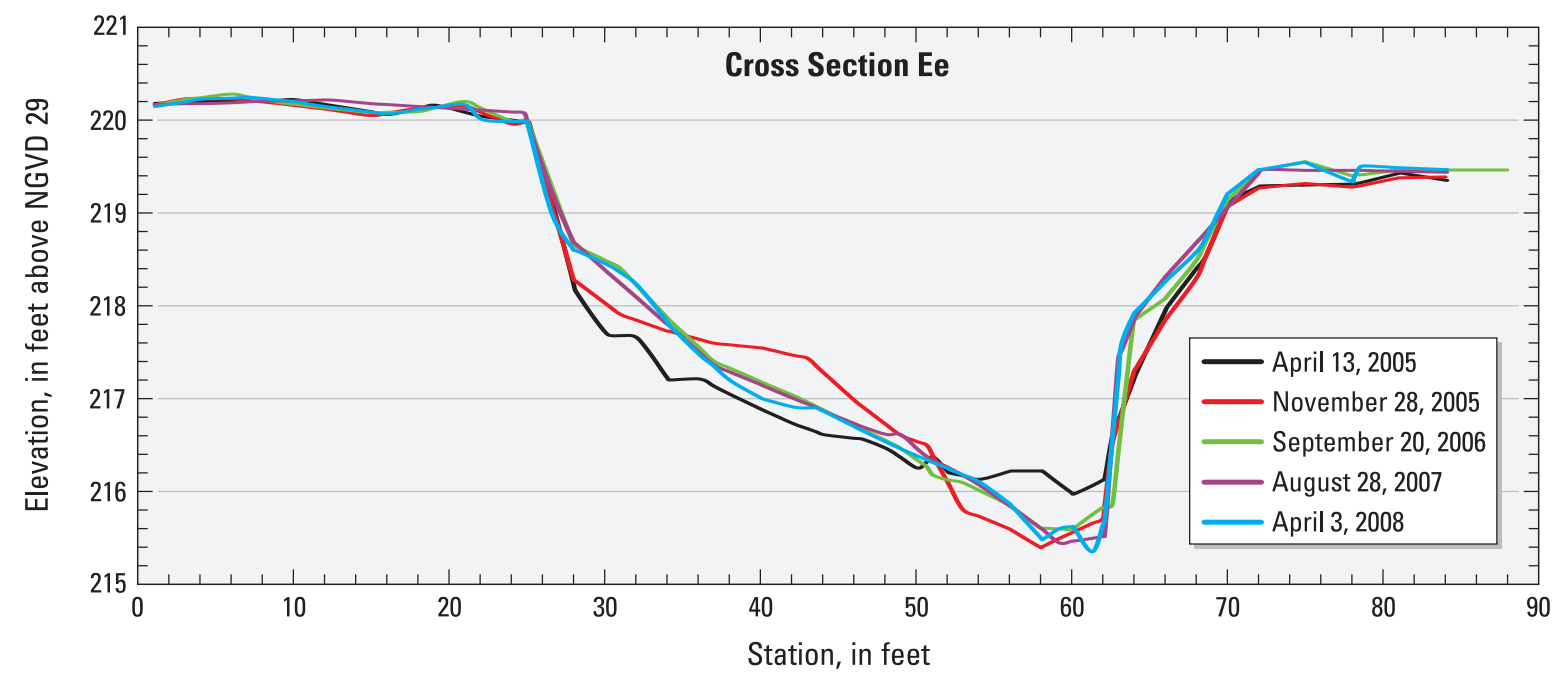

Figure 20. Post-restoration cross-section geometry at permanent cross section Ee, April 2005 through April 2008.

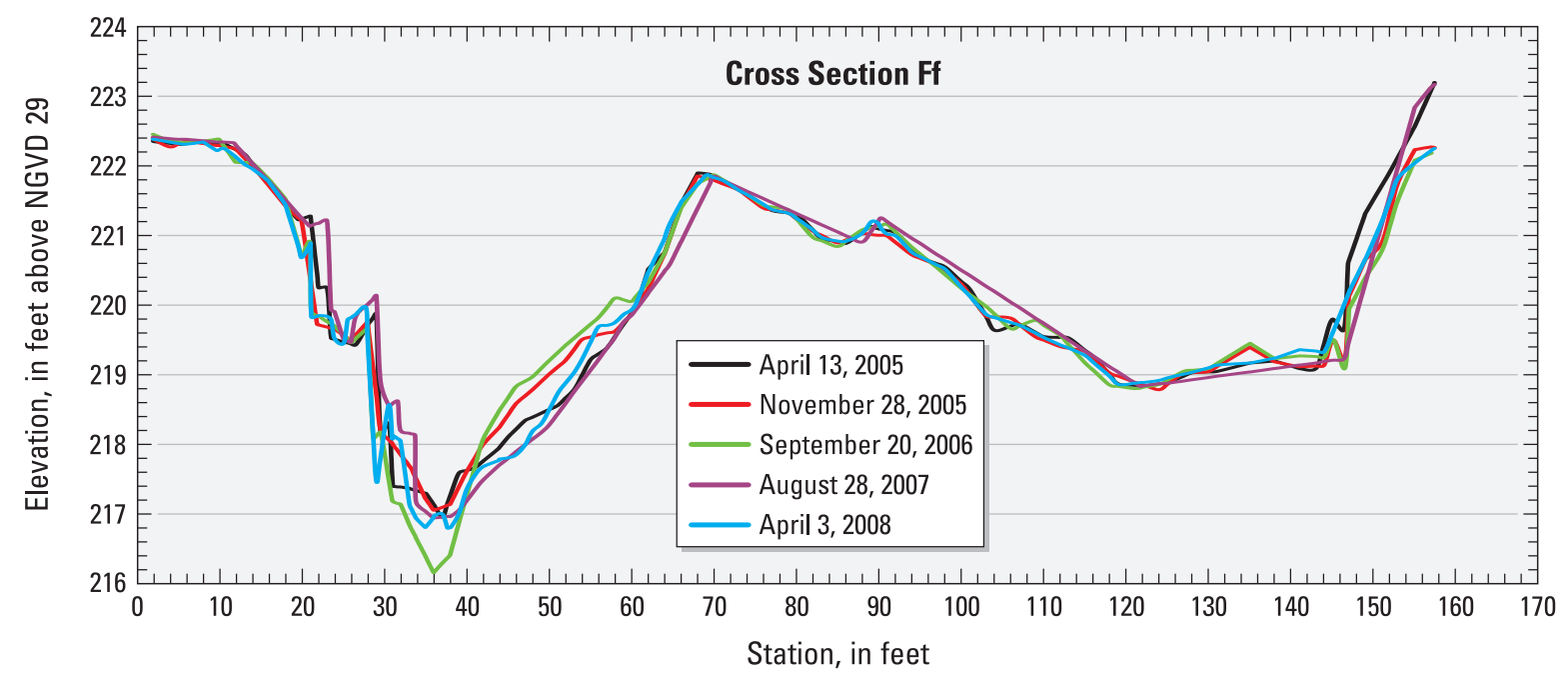

Figure 21. Post-restoration cross-section geometry at permanent cross section Ff, April 2005 through April 2008. 


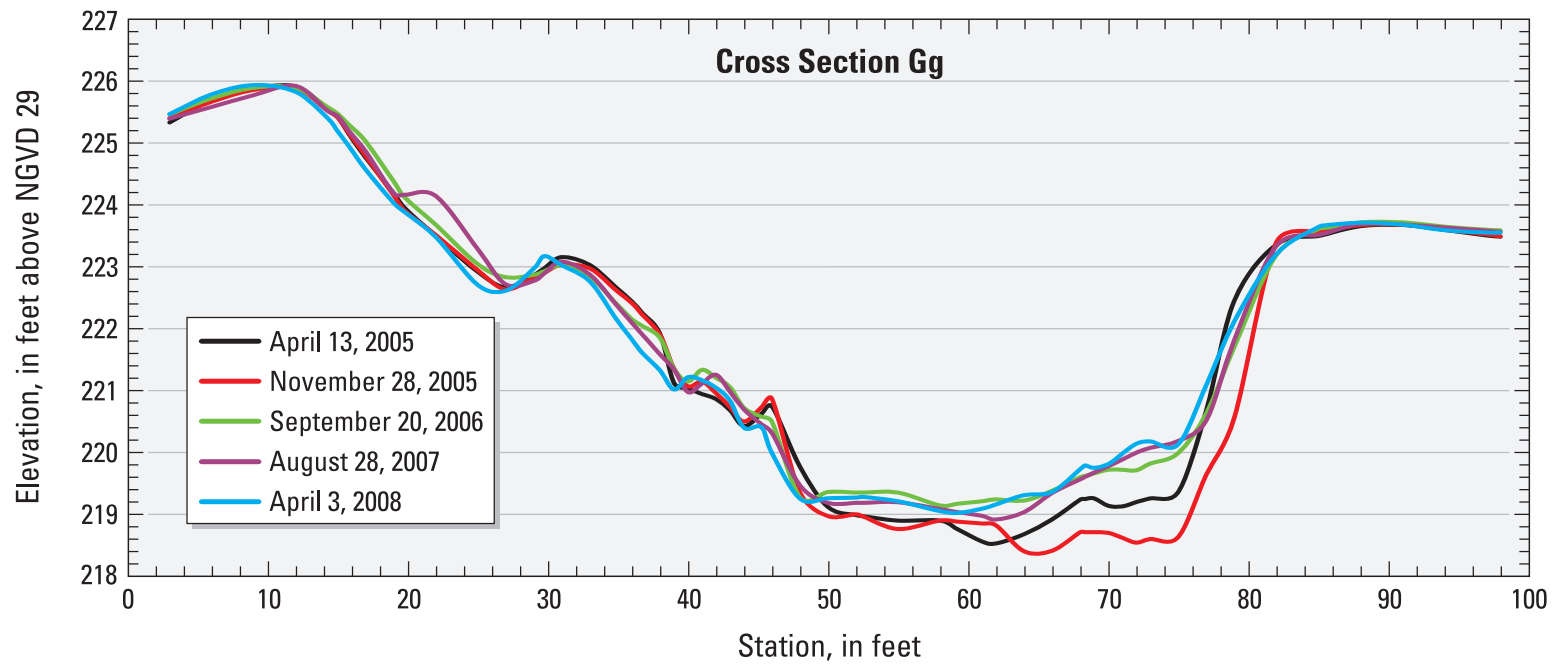

Figure 22. Post-restoration cross-section geometry at permanent cross section Gg, April 2005 through April 2008.

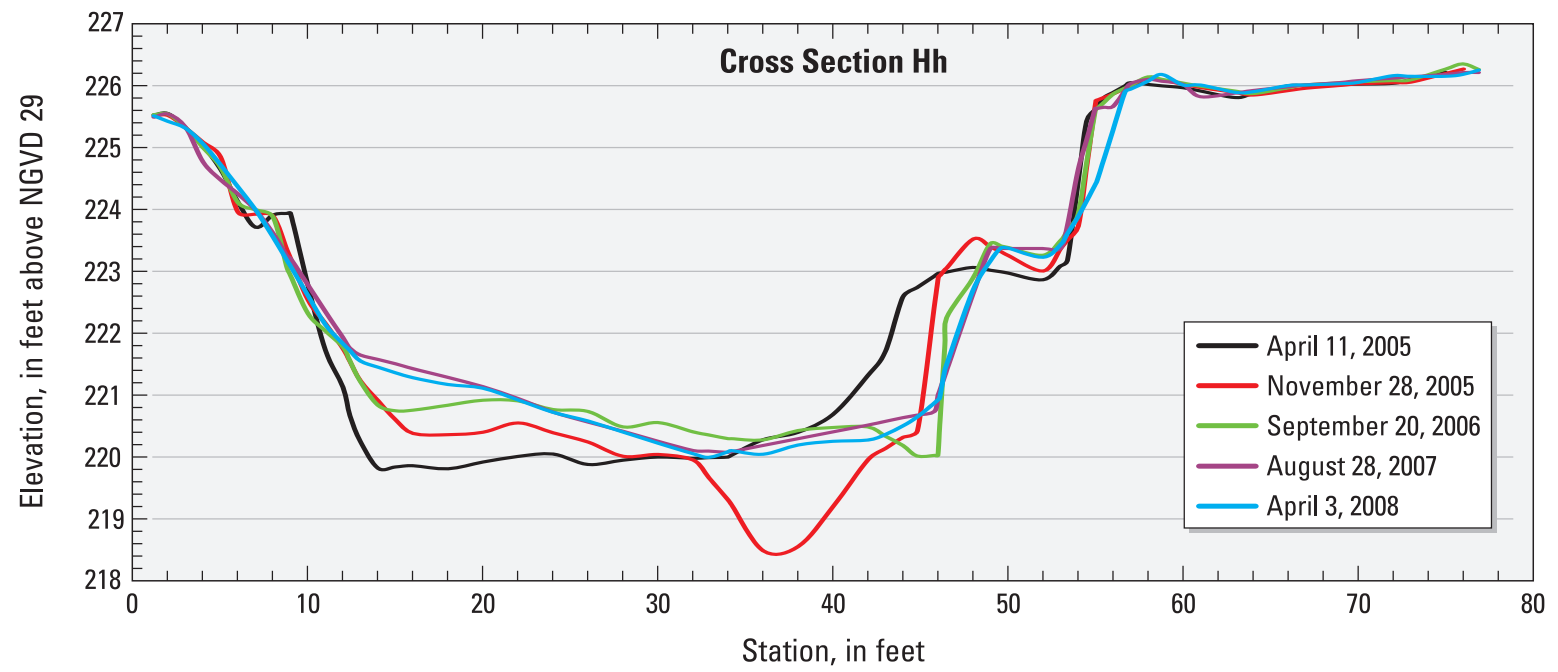

Figure 23. Post-restoration cross-section geometry at permanent cross section Hh, April 2005 through April 2008.

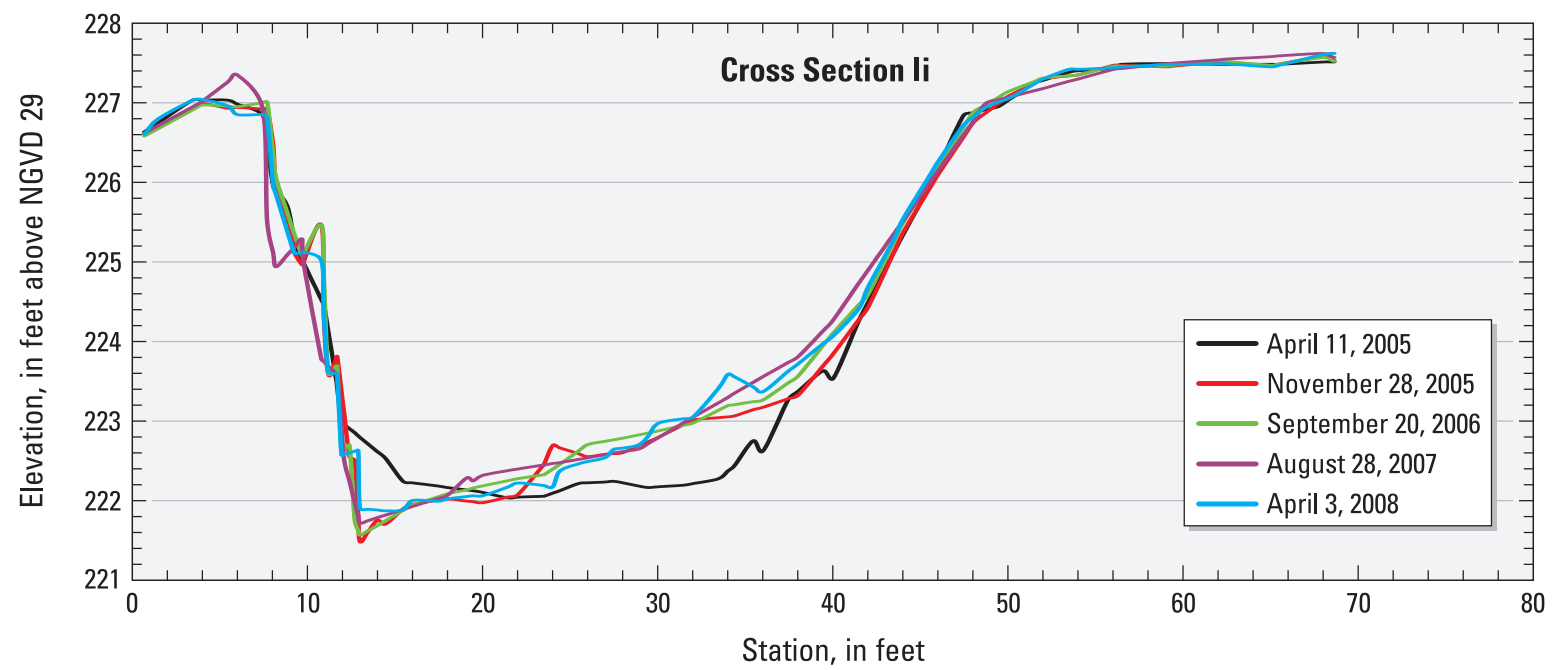

Figure 24. Post-restoration cross-section geometry at permanent cross section li, April 2005 through April 2008. 
Table 11. Changes in cross-section geometry at permanent cross-section Hh, Minebank Run study reach, 2005 through 2008.

[NGVD 29, National Geodetic Vertical Datum of 1929; ft, feet; ft², square feet; Apr., April; Nov., November; \%, percent]

\begin{tabular}{|c|c|c|c|c|c|c|c|c|c|c|}
\hline \multirow{2}{*}{$\begin{array}{c}\text { Elevation } \\
\quad \text { (ft } \\
\text { above } \\
\text { NGVD 29) }\end{array}$} & \multicolumn{5}{|c|}{$\begin{array}{c}\text { Cross-sectional area } \\
\left(\mathrm{ft}^{2}\right)\end{array}$} & \multicolumn{5}{|c|}{$\begin{array}{l}\text { Wetted perimeter } \\
\text { (ft) }\end{array}$} \\
\hline & $\begin{array}{l}\text { Apr. } \\
2005\end{array}$ & $\begin{array}{l}\text { Nov. } \\
2005\end{array}$ & 2006 & 2007 & 2008 & $\begin{array}{l}\text { Apr. } \\
2005\end{array}$ & $\begin{array}{l}\text { Nov. } \\
2005\end{array}$ & 2006 & 2007 & 2008 \\
\hline 222.00 & 57.7 & $\begin{array}{c}66.6 \\
(+15.4 \%)\end{array}$ & $\begin{array}{c}48.1 \\
(-16.6 \%)\end{array}$ & $\begin{array}{c}45.0 \\
(-22.0 \%)\end{array}$ & $\begin{array}{c}47.9 \\
(-17.0 \%)\end{array}$ & 33.6 & 36.0 & 37.2 & 36.1 & 36.5 \\
\hline 222.50 & 74.2 & $\begin{array}{c}84.1 \\
(+13.3 \%)\end{array}$ & $\begin{array}{c}66.3 \\
(-10.6 \%)\end{array}$ & $\begin{array}{c}63.2 \\
(-14.8 \%)\end{array}$ & $\begin{array}{c}66.3 \\
(-10.6 \%)\end{array}$ & 35.1 & 38.0 & 39.6 & 38.2 & 38.5 \\
\hline 223.00 & 91.6 & $\begin{array}{c}102.2 \\
(+11.6 \%)\end{array}$ & $\begin{array}{r}85.5 \\
(-6.7 \%)\end{array}$ & $\begin{array}{c}82.3 \\
(-10.2 \%)\end{array}$ & $\begin{array}{c}85.5 \\
(-6.7 \%)\end{array}$ & 38.5 & 39.7 & 41.8 & 40.2 & 40.5 \\
\hline 223.50 & 113.6 & $\begin{array}{c}121.3 \\
(+6.8 \%)\end{array}$ & $\begin{array}{c}106.1 \\
(-6.6 \%)\end{array}$ & $\begin{array}{c}102.8 \\
(-9.5 \%)\end{array}$ & $\begin{array}{c}106.3 \\
(-6.4 \%)\end{array}$ & 46.4 & 42.2 & 47.5 & 46.4 & 46.5 \\
\hline 224.00 & 136.2 & $\begin{array}{c}145.5 \\
(+6.8 \%)\end{array}$ & $\begin{array}{c}128.8 \\
(-5.4 \%)\end{array}$ & $\begin{array}{c}125.6 \\
(-7.8 \%)\end{array}$ & $\begin{array}{c}129.4 \\
(-5.0 \%)\end{array}$ & 50.3 & 51.6 & 50.0 & 48.5 & 48.9 \\
\hline 225.50 & 210.5 & $\begin{array}{c}220.2 \\
(+4.6 \%)\end{array}$ & $\begin{array}{c}203.5 \\
(-3.3 \%)\end{array}$ & $\begin{array}{c}200.8 \\
(-4.6 \%)\end{array}$ & $\begin{array}{c}205.2 \\
(-2.5 \%)\end{array}$ & 56.4 & 57.4 & 57.0 & 56.2 & 57.2 \\
\hline 225.78 & 225.6 & $\begin{array}{c}235.3 \\
(+4.3 \%)\end{array}$ & $\begin{array}{c}218.7 \\
(-3.1 \%)\end{array}$ & $\begin{array}{c}216.2 \\
(-4.2 \%)\end{array}$ & $\begin{array}{c}220.6 \\
(-2.2 \%)\end{array}$ & 58.5 & 59.2 & 59.2 & 61.6 & 58.1 \\
\hline
\end{tabular}

\begin{tabular}{|c|c|c|c|c|c|c|c|c|c|c|c|c|c|c|c|}
\hline \multirow{2}{*}{$\begin{array}{c}\text { Elevation } \\
\text { (ft } \\
\text { above } \\
\text { NGVD 29) }\end{array}$} & \multicolumn{5}{|c|}{$\begin{array}{l}\text { Hydraulic radius } \\
\text { (ft) }\end{array}$} & \multicolumn{5}{|c|}{$\begin{array}{c}\text { Channel width } \\
\text { (ft) }\end{array}$} & \multicolumn{5}{|c|}{$\begin{array}{l}\text { Mean channel depth } \\
\text { (ft) }\end{array}$} \\
\hline & $\begin{array}{l}\text { Apr. } \\
2005\end{array}$ & $\begin{array}{l}\text { Nov. } \\
2005\end{array}$ & 2006 & 2007 & 2008 & $\begin{array}{l}\text { Apr. } \\
2005\end{array}$ & $\begin{array}{l}\text { Nov. } \\
2005\end{array}$ & 2006 & 2007 & 2008 & $\begin{array}{l}\text { Apr. } \\
2005\end{array}$ & $\begin{array}{l}\text { Nov. } \\
2005\end{array}$ & 2006 & 2007 & 2008 \\
\hline 222.00 & 1.72 & 1.85 & 1.29 & 1.25 & 1.31 & 32.6 & 34.2 & 35.3 & 35.5 & 35.8 & 1.77 & 1.95 & 1.36 & 1.27 & 1.34 \\
\hline 222.50 & 2.11 & 2.21 & 1.67 & 1.65 & 1.72 & 33.6 & 35.7 & 37.4 & 37.3 & 37.6 & 2.21 & 2.36 & 1.77 & 1.69 & 1.76 \\
\hline 223.00 & 2.38 & 2.57 & 2.05 & 2.05 & 2.11 & 36.8 & 37.0 & 39.3 & 39.1 & 39.3 & 2.49 & 2.76 & 2.18 & 2.10 & 2.18 \\
\hline 224.00 & 2.71 & 2.82 & 2.58 & 2.59 & 2.65 & 47.5 & 48.2 & 46.8 & 46.7 & 47.3 & 2.87 & 3.02 & 2.75 & 2.69 & 2.74 \\
\hline 224.50 & 3.08 & 3.21 & 2.92 & 2.93 & 2.99 & 48.7 & 49.0 & 48.9 & 49.0 & 49.5 & 3.29 & 3.47 & 3.12 & 3.05 & 3.10 \\
\hline 225.00 & 3.44 & 3.56 & 3.26 & 3.25 & 3.33 & 50.2 & 50.2 & 50.6 & 51.2 & 51.5 & 3.69 & 3.87 & 3.51 & 3.41 & 3.47 \\
\hline 225.50 & 3.73 & 3.84 & 3.57 & 3.57 & 3.59 & 52.4 & 52.7 & 52.8 & 53.5 & 54.8 & 4.02 & 4.18 & 3.85 & 3.57 & 3.74 \\
\hline
\end{tabular}

Note: Percentages shown in parentheses under cross-sectional areas represent the percent change in area from the April 2005 survey. 
Table 12. Summary of variability of cross-sectional characteristics in the Minebank Run study reach, 2005 through 2008.

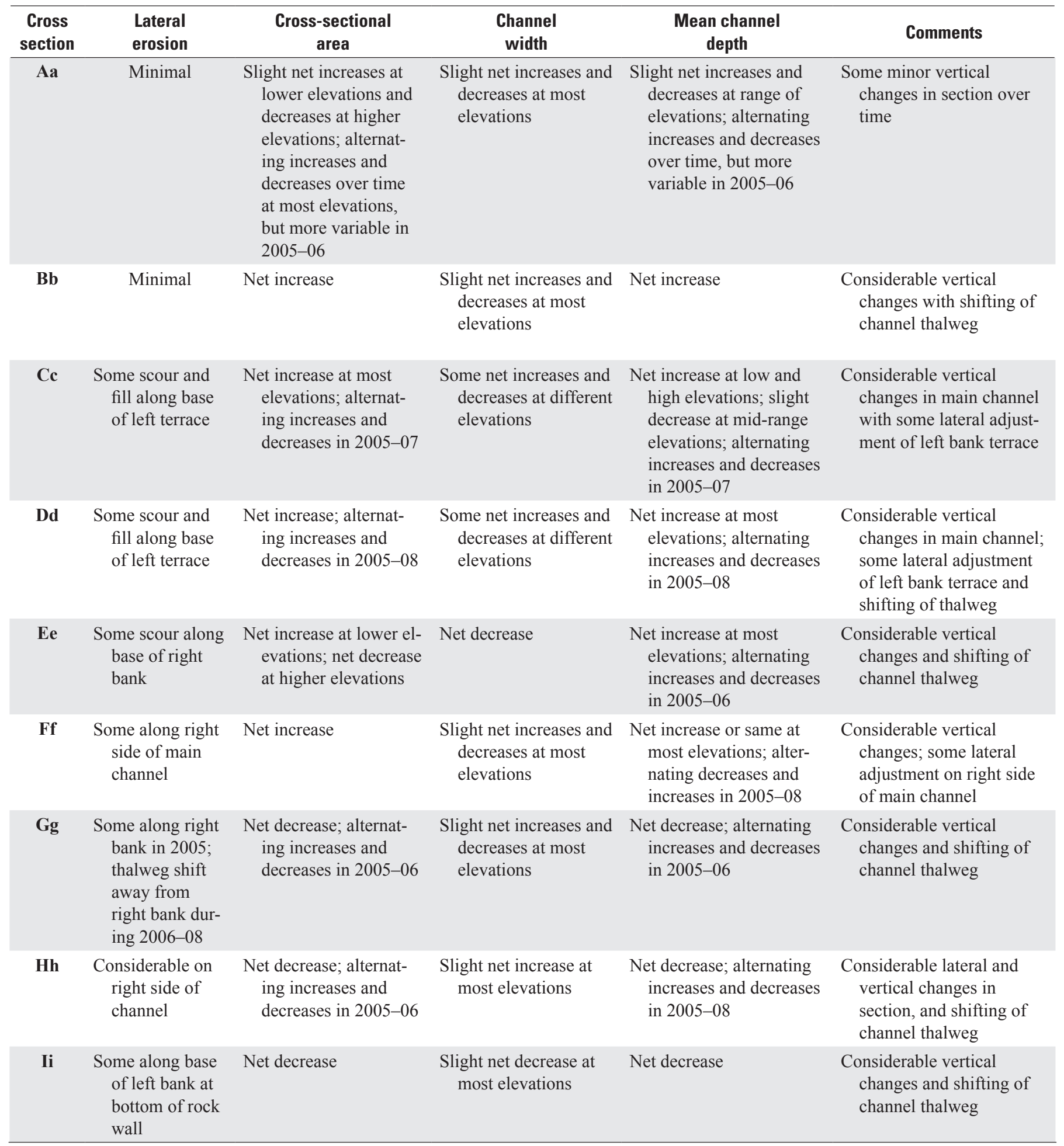


with some overall aggradation on the left side of the section and the right overbank. Increasing elevations on the right overbank indicate that overbank flows may have deposited a $0.10-0.20-\mathrm{ft}$ depth of fine sediment in the overbank area between 2005 and 2008 .

Cross section Ff showed net increases in cross-sectional area over time, along with mean depths that showed net increases or were approximately the same at different elevations over time. The channel thalweg was confined to the center of the main channel by a riprap rock wall that now composes the left bank in the section, but showed considerable variability in elevation over time. The net increases in crosssectional area and mean depth along with alternating increases and decreases between surveys indicates that sand and gravel could be temporarily stored in this location after certain storm events despite overall degradation during the post-restoration monitoring period.

Cross section Gg showed a net decrease in cross-sectional area and mean depth over time. Some lateral erosion on the right bank was evident during the November 2005 survey, after which the thalweg began gradually shifting toward the center of the channel as the right side of the section aggraded over time. The decrease in cross-sectional area and mean depth, along with the shift in thalweg location over time, indicates an aggrading channel bed at cross section Gg with a net increase in storage of sediment that is transported during storm events (Doheny and others, 2007).

Cross section Ii showed net decreases in cross-sectional area and mean depth over time, along with a shift in the thalweg of the channel toward the left bank as the right side of the section aggraded over time. The net decreases in crosssectional area and mean depth, along with the shift in thalweg location over time, indicates an aggrading channel bed at cross section Ii with a net increase in storage of sediment that is transported during storm events (Doheny and others, 2007).

A summary of geomorphic conditions that were interpreted from changes in the cross sections during the postrestoration monitoring period is shown in figure 25. Cross sections $\mathrm{Gg}, \mathrm{Hh}$, and Ii, which represent approximately the upper 30 percent of the study reach, appear to be primary locations for sediment storage within the study reach. The increase in sediment storage in this area could be due to varying percentages of stormflow that now bypass the main channel by entering a small section of the pre-restoration stream channel about $250 \mathrm{ft}$ upstream of cross section Ii, and then re-entering the main channel about $65 \mathrm{ft}$ downstream of cross section Ii (Harrison and others, 2011). Cross sections Gg and Hh, which are in the only locations of the study reach that were not physically altered by the restoration work, indicate some lateral instability over time. This could be a result of realignment of the stream channel after it was physically moved in the area just upstream of these cross sections. Cross section Ff shows overall degradation of the channel bed with indications of temporary sediment storage and removal over time. Cross section Ee indicates a combination of aggradation and degradation of the channel bed as a result of the thalweg shift toward the base of the right bank over time. Cross sections $\mathrm{Bb}$, $\mathrm{Cc}$, and Dd indicate overall bed degradation with only minor or no lateral erosion. Cross sections Dd and Ee were the main locations in the study reach with evidence of sediment deposition on the flood plain due to stormflows that can overtop the right bank in these locations. Cross section Aa appears to be the most stable section in the study reach, with minor aggradation and degradation of the channel bed over time and little to no lateral erosion.

Based on analysis of the cross sections in both the preand post-restoration monitoring periods, lateral erosion has been considerably reduced due to elimination of nearly all cut banks in the study reach during the restoration. The cross sections showed little indication of any channel widening over time. Flood flows now have the ability to contact sections of the overbank area, and also bypass the main channel in small sections of the study reach, which was not possible in the pre-restoration monitoring period. Much of the geomorphic variability displayed in the post-restoration monitoring period is due to aggradation and degradation of the channel bed and shifting of the channel thalweg, instead of channel degradation and widening, and lateral erosion from receding cut banks, which was commonly observed during the pre-restoration monitoring period. Most locations in the study reach continue to show alternating patterns of sediment storage and removal over time. At least four of the cross sections indicated reduced variability in cross-sectional area and mean depth between surveys conducted from 2006 to 2008 (table 12), however. This indicates that the stream channel could be establishing a dynamic equilibrium and a more stable geometry after the initial geomorphic response observed in 2005 and 2006, just after the disturbances created by the restoration work.

\section{Hydraulic-Geometry Relations}

Doheny and others (2006) defined hydraulic-geometry relations between discharge and hydraulic variables such as cross-sectional area, mean channel depth, channel width, and mean flow velocity to quantify changes in these variables to changes in discharge at Minebank Run during water years 2002 through 2004. The relations presented were based on data from discharge measurements associated with the operation of USGS streamgage 0158397967, Minebank Run near Glen Arm, Maryland, and most were made just downstream from the streamgage during that time period. One hundred ten measurements were available for analysis in the prerestoration period, with discharges ranging from $0.04 \mathrm{ft}^{3} / \mathrm{s}$ to $1,390 \mathrm{ft}^{3} / \mathrm{s}$. Ninety-six of those measurements were characterized as having discharges less than $10 \mathrm{ft}^{3} / \mathrm{s}$. An additional 76 measurements were made during the post-restoration monitoring period in water years 2005 through 2008, however, only 1 of these measurements is characterized as having a discharge greater than $10 \mathrm{ft}^{3} / \mathrm{s}$. As data are not available in the postrestoration period to adequately describe hydraulic-geometry relations with discharges greater than $10 \mathrm{ft}^{3} / \mathrm{s}$, the analysis 


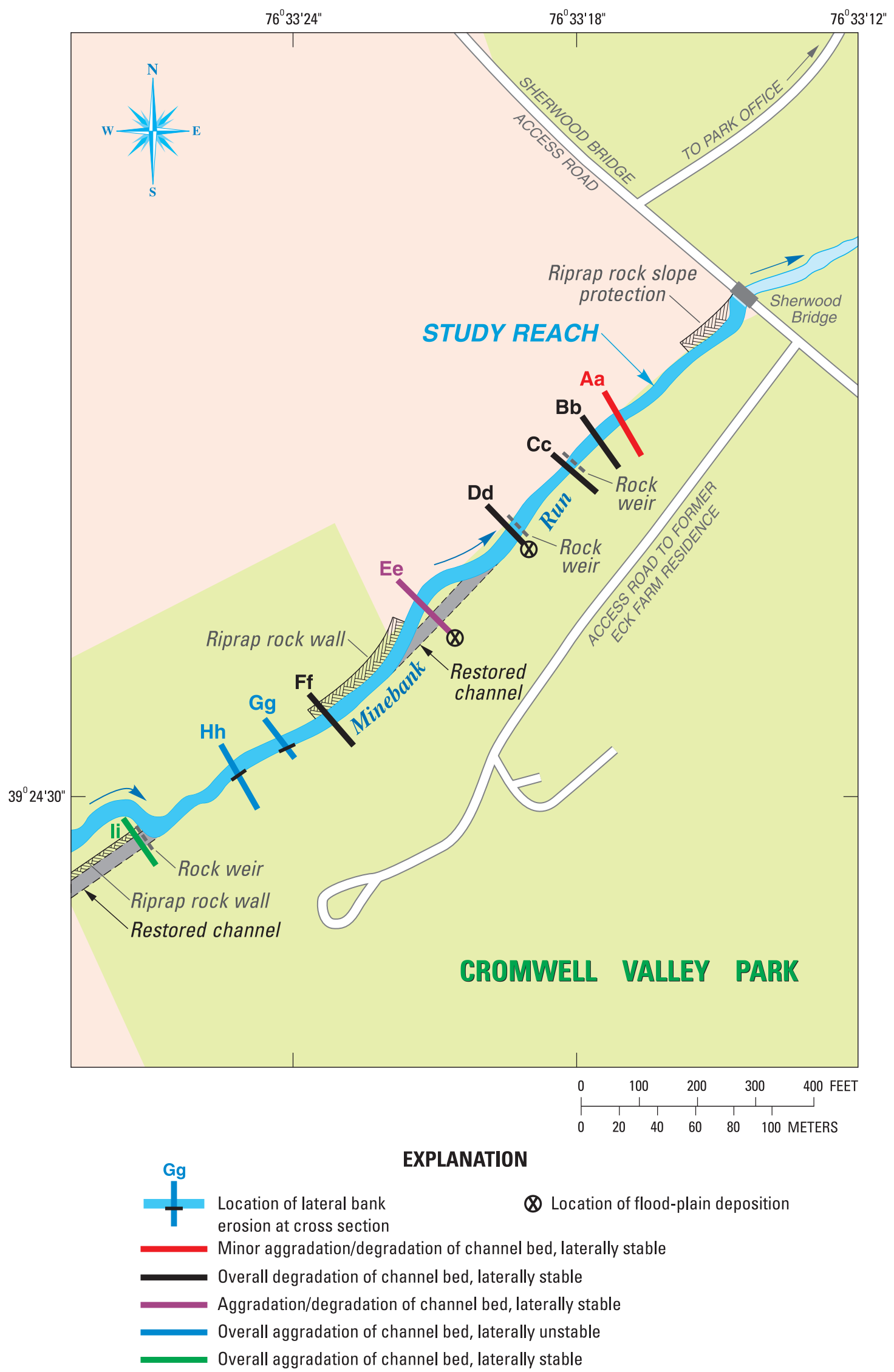

Figure 25. Summary of post-restoration geomorphic conditions in the Minebank Run study reach, 2005 through 2008. 
presented below pertains only to relations that were developed based on measurements with discharges less than $10 \mathrm{ft}^{3} / \mathrm{s}$.

Plots of hydraulic-geometry relations of cross-sectional area, channel width, mean channel depth, and mean velocity against discharge were developed (fig. 26). Most of the variables show moderate to strong linear relations with discharge. In the pre-restoration period, the strongest relation was between cross-sectional area and discharge, whereas in the post-restoration period, the strongest relation was between mean flow velocity and discharge. These relations indicate that channel depth in the vicinity of the streamgage was essentially unchanged by restoration activities, however, channel width increased, and as a result, the cross-sectional area increased. This increase in cross-sectional area caused a proportional decrease in mean flow velocity for comparable discharges. The trend of the relation between discharge and mean velocity indicates that the change in the relation likely does not extend far above discharges of $10 \mathrm{ft}^{3} / \mathrm{s}$.

The relatively flat slope associated with the post-restoration relation between discharge and channel width is indicative of a rectangular channel cross section that has remained relatively stable in the general location of the streamgage during that period. It also explains the increase in slope of the relation between discharge and mean flow velocity from the pre- to post-restoration period. Because discharge is the product of cross-sectional area and mean flow velocity, as the magnitude of discharge has become less sensitive to channel width, and thus cross-sectional area, it has become more sensitive to mean flow velocity.

\section{Grain-Size Distribution}

Grain-size distributions were determined for sediment in the channel bed of the study reach between 2002 and 2008 by use of pebble counts of the surficial channel bed sediments at each cross section (Wolman, 1954; Doheny and others, 2007). The distributions were developed for each cross section based on the percentages of counted pebbles that fall within 12 particle-size ranges of sand, gravel, cobbles, and boulders. Pre-restoration pebble counts were conducted in selected locations of the study reach in May 2002, and at all permanent cross section locations during May-June 2003. These data were previously published in Doheny and others (2007). Postrestoration pebble counts were conducted at all permanent cross section locations during May 2005, October 2006, and April 2008. Cumulative frequency distributions of percent finer were developed for the surficial bed material based on the pebble count data. The median particle diameter (d50), or particle diameter associated with 50 percent of the material being finer, was determined for the pebble counts at each cross section. Grain-size distributions from the pebble counts also were combined to develop composite analyses of the surficial bed material for the entire study reach for 2003, 2005, 2006, and 2008. The grain-size distributions from these years also were compared to the selected pebble counts from May 2002 that were made at the three groundwater transect locations, corresponding to permanent cross sections Ee, Ff, and Gg, respectively (Doheny and others, 2007).

A wide range of grain sizes was present within the Minebank Run study reach in May-June 2003, prior to restoration of the stream channel. The majority of grain sizes fell between medium gravel $(16 \mathrm{~mm})$ and small cobbles (128 $\mathrm{mm})$. The $\mathrm{d} 50$ for the study reach at this time was approximately $20.5 \mathrm{~mm}$, which falls within the range of coarse gravel. The analysis also indicated that over 24 percent of the pebbles counted throughout the study reach were sand (Doheny and others, 2007). More than half of the locations in the study reach had large percentages of sand, including cross sections $\mathrm{Bb}$ (30.0 percent); Ee (30.0 percent); Gg (25.0 percent); Hh (61.4 percent); and Ii (35.0 percent). Cross sections $\mathrm{Gg}, \mathrm{Hh}$, and Ii collectively represented approximately the upper 28 percent of the study reach at that point in time. Cross sections $\mathrm{Bb}, \mathrm{Ee}$, and Ii were located near meanders in the stream channel, which indicated that finer material was being temporarily stored in these locations and transported during storm events. The cross-section geometry at cross section $\mathrm{Bb}$ also indicated a net aggradation of the channel bed during that period of time. Cross section Hh, which was in a fairly straight reach, was also a location where finer material could be stored because of a braided sand and gravel bar that was acting as a grade control at the start of the study.

Before restoration, cross sections $\mathrm{Cc}$, Dd, and $\mathrm{Ff}$ had the coarsest distribution of grain sizes based on pebble counts conducted in May-June 2003, including a higher percentage of gravel and cobbles than the other locations. Cross section Aa had a considerable amount of gravel and some sand, but fewer cobbles. Cross sections Aa, Cc, and Ff were in fairly straight reaches, which indicated that finer material was being transported through these locations during storms with relatively small amounts of net storage. The cross-section geometry at cross sections Aa, Dd, and Ff also indicated lateral erosion of at least one of the channel banks prior to restoration, which may have exposed coarser bed material as the channel migrated. Only a few boulders were present in the entire study reach at that point in time (Doheny and others, 2007).

Pebble-count data that were collected during May 2005, October 2006, and April 2008 were used to develop grain-size distributions of percent finer for the surficial bed material in the study reach after restoration of the stream channel. The results are shown in tables 13-15.

There was considerable coarsening of the channel bed just after restoration of the stream channel (table 13). Most d50 values fall approximately within the range of coarse gravel $(32 \mathrm{~mm})$ to small cobbles $(128 \mathrm{~mm})$. Only cross section $\mathrm{Hh}$ indicates a large percentage of sand (35 percent) in May 2005. Much of the channel bed coarsening can be attributed directly to larger bed material being placed in the channel bed during reconstruction of the stream channel. However, even cross sections $\mathrm{Gg}$ and $\mathrm{Hh}$, which are located in areas that were not directly altered physically by restoration activities, showed considerable reductions in percentages of sand in 2005. Cross 

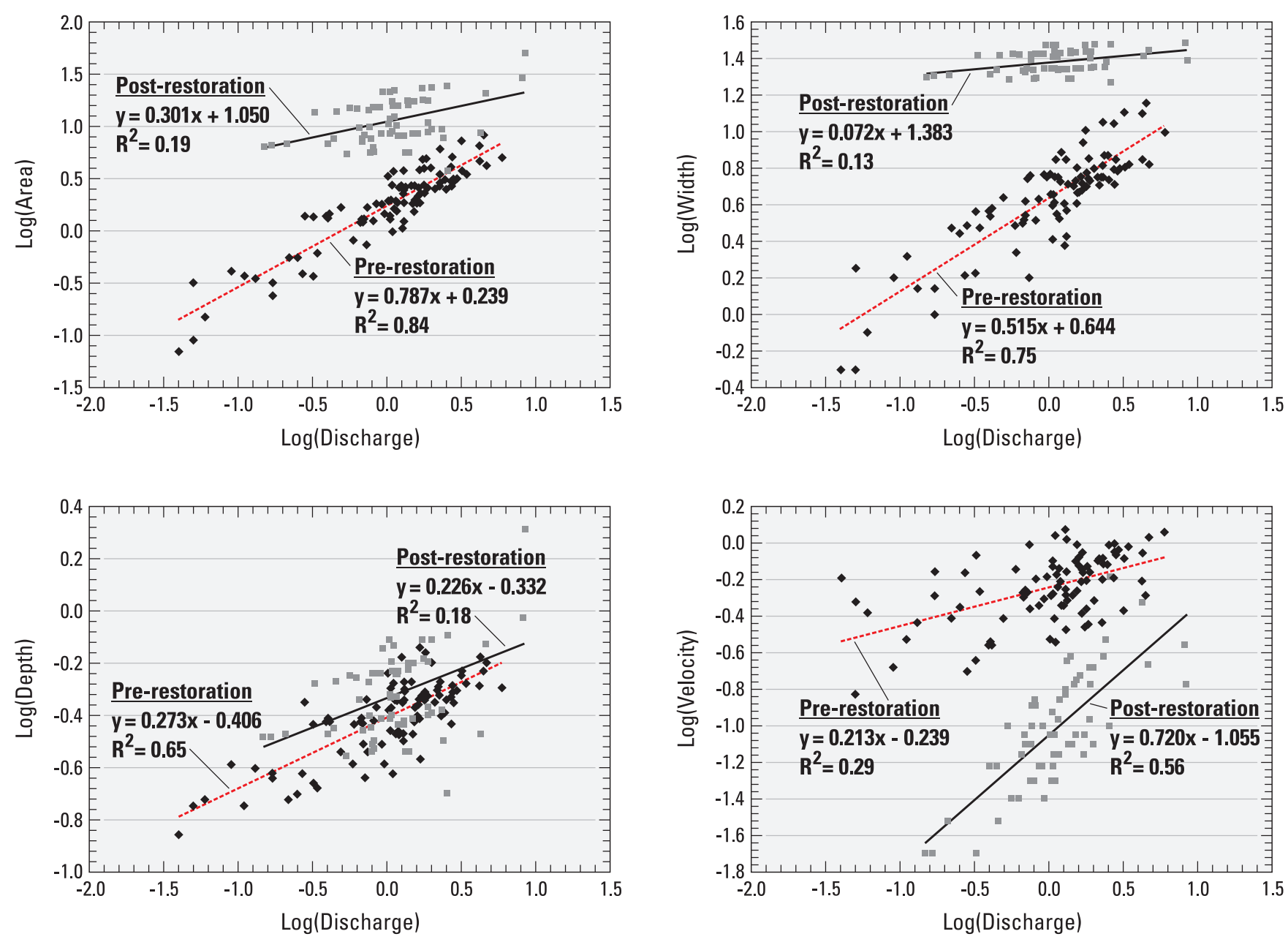

Figure 26. Comparison of pre- and post-restoration hydraulic-geometry relations of cross-sectional area, channel width, mean channel depth, and mean velocity against discharge using discharge measurements of less than 10 cubic feet per second at U.S. Geological Survey station 0158397967, Minebank Run near Glen Arm, Maryland.

sections Ee and Ii also showed considerable reductions in percentages of sand, but are not directly comparable between May-June 2003 and May 2005 due to physical relocation of the stream channel in these areas during the restoration. Cross section $\mathrm{Bb}$ showed the largest reduction in percentage of sand, with a reduction from 30 percent in May-June 2003 to 1 percent in May 2005.

A large increase in sand and gravel percentages in the study reach occurred between May 2005 and October 2006 (table 14). Large storms in the watershed in October 2005 and June 2006 are the most likely cause of these increases. All cross sections showed increases in sand percentages except for cross section $\mathrm{Hh}$, which showed a slight decrease from 35 percent in May 2005 to 28 percent in October 2006. All cross sections showed increasing or nearly equivalent percentages of gravel in all class sizes. The locations with the largest increases in sand and gravel percentages between May 2005 and October 2006 were at cross sections Dd, Ee, and Ii.
Storage of fine material at these cross sections could be due to two rock weirs that were installed downstream of these locations during the restoration to establish grade control in selected areas of the stream channel.

Percentages of sand in April 2008 were elevated in comparison to those from May 2005, but considerably less than those found in October 2006 (table 15). Cross sections Dd, Ee, and Ii, which showed the largest increases in sand percentages in October 2006, all showed considerable decreases in April 2008. The largest decrease was at cross section Dd, where the percentage of sand decreased from 46.0 percent to 2.0 percent between October 2006 and April 2008. Streamflow records from station 0158397967, Minebank Run near Glen Arm, Maryland, indicated only one large storm event in the watershed that occurred during this time period, in November 2006. This indicates that in the restored state, the stream channel is continuing to undergo alternating periods of sediment storage and erosion in different sections of the study reach. The lack 
Table 13. Cumulative distribution of grain sizes, in percent finer, for surficial bed material at permanent cross section locations in the Minebank Run study reach, May 2005.

[Values represent the percentage of total particles that are finer than the particle size indicated in the particle size limit column of each row of values; $\mathrm{mm}$, millimeters; \%, percent]

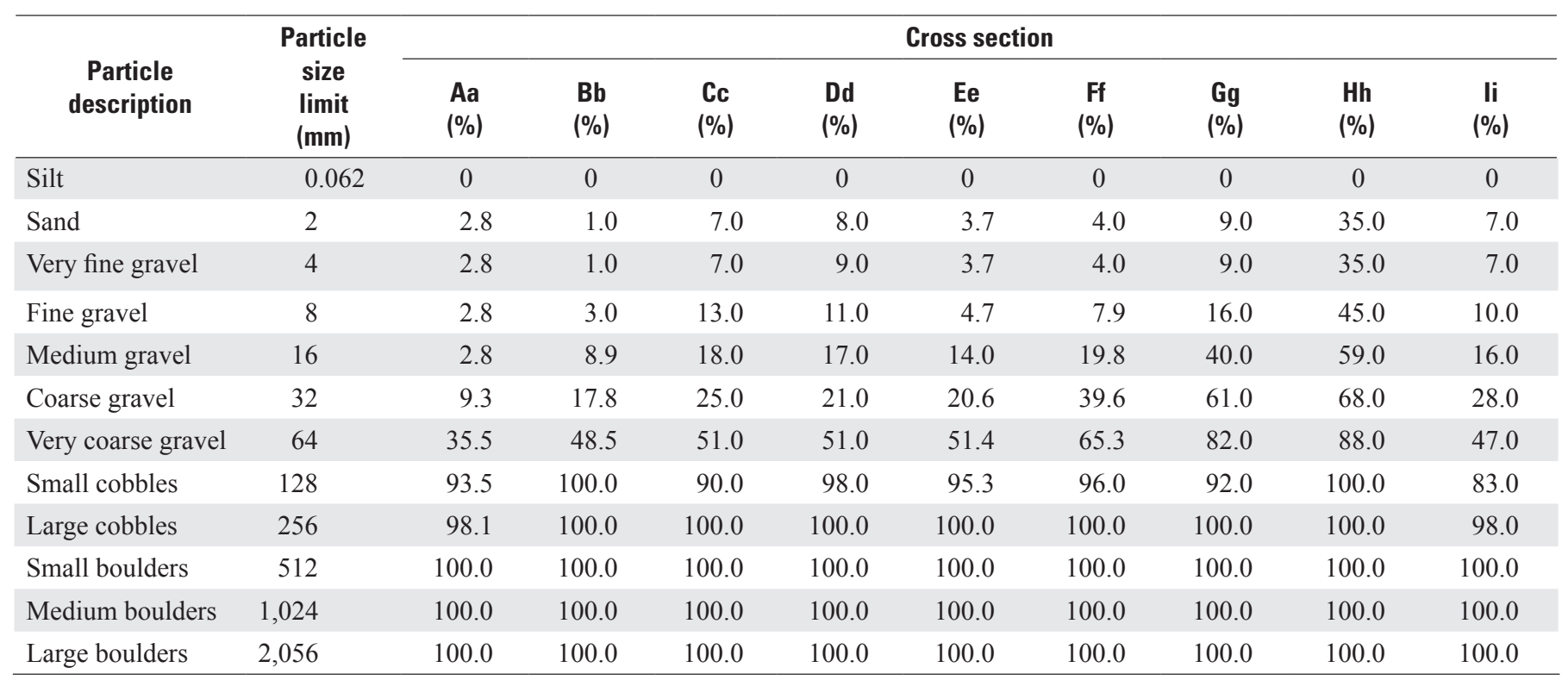

Table 14. Cumulative distribution of grain sizes, in percent finer, for surficial bed material at permanent cross section locations in the Minebank Run study reach, October 2006.

[Values represent the percentage of total particles that are finer than the particle size indicated in the particle size limit column of each row of values; mm, millimeters; \%, percent]

\begin{tabular}{|c|c|c|c|c|c|c|c|c|c|c|}
\hline \multirow{2}{*}{$\begin{array}{c}\text { Particle } \\
\text { description }\end{array}$} & \multirow{2}{*}{$\begin{array}{c}\text { Particle } \\
\text { size } \\
\text { limit } \\
(\mathrm{mm})\end{array}$} & \multicolumn{9}{|c|}{ Cross section } \\
\hline & & $\begin{array}{l}\mathrm{Aa} \\
(\%)\end{array}$ & $\begin{array}{l}\mathrm{Bb} \\
(\%)\end{array}$ & $\begin{array}{l}\text { Cc } \\
(\%)\end{array}$ & $\begin{array}{l}\text { Dd } \\
(\%)\end{array}$ & $\begin{array}{l}\text { Ee } \\
(\%)\end{array}$ & $\begin{array}{l}\text { Ff } \\
(\%)\end{array}$ & $\begin{array}{l}\mathrm{Gg} \\
(\%)\end{array}$ & $\begin{array}{l}\mathrm{Hh} \\
(\%)\end{array}$ & $\begin{array}{c}\mathrm{li} \\
(\%)\end{array}$ \\
\hline Sand & 2 & 10.0 & 18.0 & 14.0 & 46.0 & 56.0 & 16.0 & 14.0 & 28.0 & 56.0 \\
\hline Very fine gravel & 4 & 10.0 & 28.0 & 19.0 & 54.0 & 69.0 & 24.0 & 26.0 & 37.0 & 71.0 \\
\hline Medium gravel & 16 & 25.0 & 43.0 & 35.0 & 61.0 & 87.0 & 43.0 & 57.0 & 65.0 & 78.0 \\
\hline Coarse gravel & 32 & 33.0 & 62.0 & 54.0 & 70.0 & 91.0 & 52.0 & 73.0 & 80.0 & 87.0 \\
\hline Very coarse gravel & 64 & 62.0 & 78.0 & 72.0 & 79.0 & 96.0 & 79.0 & 87.0 & 97.0 & 94.0 \\
\hline Small cobbles & 128 & 88.0 & 94.0 & 92.0 & 95.0 & 98.0 & 98.0 & 99.0 & 100.0 & 99.0 \\
\hline Large boulders & 2,056 & 100.0 & 100.0 & 100.0 & 100.0 & 100.0 & 100.0 & 100.0 & 100.0 & 100.0 \\
\hline
\end{tabular}


Table 15. Cumulative distribution of grain sizes, in percent finer, for surficial bed material at permanent cross section locations in the Minebank Run study reach, April 2008.

[Values represent the percentage of total particles that are finer than the particle size indicated in the particle size limit column of each row of values; $\mathrm{mm}$, millimeters; \%, percent]

\begin{tabular}{|c|c|c|c|c|c|c|c|c|c|c|}
\hline $\begin{array}{c}\text { Particle } \\
\text { description }\end{array}$ & $\begin{array}{c}\text { Particle } \\
\text { size } \\
\text { limit } \\
(\mathrm{mm})\end{array}$ & \multicolumn{9}{|c|}{ Cross section } \\
\hline Silt & 0.062 & 0 & 0 & 0 & 0 & 0 & 0 & 0 & 0 & 0 \\
\hline Sand & 2 & 11.0 & 7.0 & 11.0 & 2.0 & 38.0 & 17.0 & 7.0 & 23.0 & 22.0 \\
\hline Very fine gravel & 4 & 20.0 & 20.0 & 18.0 & 5.0 & 43.0 & 38.0 & 22.0 & 36.0 & 39.0 \\
\hline Medium gravel & 16 & 50.0 & 53.0 & 48.0 & 30.0 & 67.0 & 67.0 & 60.0 & 68.0 & 64.0 \\
\hline Coarse gravel & 32 & 70.0 & 70.0 & 67.0 & 61.0 & 79.0 & 77.0 & 77.0 & 83.0 & 72.0 \\
\hline Very coarse gravel & 64 & 86.0 & 88.0 & 83.0 & 85.0 & 89.0 & 86.0 & 95.0 & 93.0 & 84.0 \\
\hline Small cobbles & 128 & 99.0 & 98.0 & 96.0 & 98.0 & 99.0 & 96.0 & 99.0 & 98.0 & 97.0 \\
\hline Large boulders & 2,056 & 100.0 & 100.0 & 100.0 & 100.0 & 100.0 & 100.0 & 100.0 & 100.0 & 100.0 \\
\hline
\end{tabular}

of large storm events between October 2006 and April 2008 indicates that smaller, less extreme storm events could be playing an enhanced role in transporting sand through the study reach over time.

Median particle diameters for all pebble counts conducted in the study reach between 2002 and 2008 were determined (Doheny and others, 2007). The results are presented in table 16.

A slight coarsening of the channel bed prior to restoration is evident at the three groundwater transect locations, which correspond to permanent cross sections Ee, $\mathrm{Ff}$, and $\mathrm{Gg}$ (Doheny and others, 2007) (table 16). In 2005, the channel bed was considerably coarser in all cross sections than in 2003 just after the restoration work was completed. In 2006, the channel bed was considerably finer in all cross sections approximately 1.5 years after the restoration work was completed. Except for cross section Ee, which was physically moved within the valley during the restoration, the $\mathrm{d} 50$ values from 2006 are very similar to those found in equivalent locations in 2002 , prior to restoration.

In 2008, all cross sections in the study reach were considerably finer than in 2005, just after the restoration work was completed. Different sections of the study reach, however, varied in becoming finer or coarser between 2006 and 2008. For example, the lowermost section of the study reach at cross sections $\mathrm{Aa}, \mathrm{Bb}$, and $\mathrm{Cc}$ showed continued fining between 2006 and 2008 whereas cross sections Dd and Ee became coarser again. Cross sections Ff became finer but cross sections $\mathrm{Gg}$ and $\mathrm{Hh}$ remained almost the same between 2006 and 2008. Cross section Ii became coarser between 2006 and 2008. This indicates that the stream channel underwent an adjustment period after restoration where the channel bed was becoming finer throughout the study reach between 2005 and 2006. Between 2006 and 2008, different sections of the study reach were alternating between continued fining and coarsening after the initial post-restoration adjustment period.

Data from the pebble counts at each of the nine cross sections also were combined to develop composite grain-size distributions of the surficial bed material for the entire study reach over time. Each distribution was developed using over 900 pebbles that were collected in the nine cross sections during May-June 2003, May 2005, October 2006, and April 2008 (Doheny and others, 2007). The grain-size distributions and computations of percent finer for the composite pebble counts in the Minebank Run study reach are shown in table 17. These results are shown graphically in figure 27 . 
Table 16. Median particle diameter from pebble counts associated with each permanent cross section in the Minebank Run study reach, 2002 through 2008.

[d50, median particle diameter; mm, millimeters; ---, not applicable; $<$, less than]

\begin{tabular}{cccccc}
\hline \multirow{2}{*}{$\begin{array}{c}\text { Cross } \\
\text { section }\end{array}$} & \multicolumn{5}{c}{$\begin{array}{c}\mathbf{d 5 0} \\
(\mathbf{m m})\end{array}$} \\
\cline { 2 - 6 } & 2002 & 2003 & 2005 & 2006 & 2008 \\
\hline Aa & --- & 20.5 & 75.0 & 50.0 & 16.0 \\
\hline Bb & --- & 9.0 & 65.0 & 21.0 & 15.0 \\
\hline Cc & --- & 50.0 & 63.0 & 30.0 & 17.0 \\
\hline Dd & --- & 36.0 & 63.0 & 3.0 & 24.0 \\
\hline Ee & 18.0 & 30.0 & 62.0 & $<2.0$ & 6.5 \\
\hline Ff & 31.5 & 36.0 & 42.0 & 30.0 & 7.5 \\
\hline Gg & 10.0 & 14.0 & 22.0 & 11.0 & 11.0 \\
\hline Hh & --- & $<2.0$ & 10.5 & 10.0 & 9.0 \\
\hline $\mathbf{I i}^{1}$ & --- & 10.2 & 70.0 & $<2.0$ & 7.0 \\
\hline
\end{tabular}

${ }^{1}$ Stream channel was physically moved during the restoration.

Table 17. Grain-size distributions and computation of percent finer from composite pebble counts at all permanent cross sections, Minebank Run study reach, 2003 through 2008.

[mm, millimeters; \%, percent]

\begin{tabular}{|c|c|c|c|c|c|}
\hline \multirow{2}{*}{$\begin{array}{c}\text { Particle } \\
\text { description }\end{array}$} & \multirow{2}{*}{$\begin{array}{l}\text { Particle } \\
\text { size limit } \\
\text { (mm) }\end{array}$} & \multicolumn{4}{|c|}{$\begin{array}{l}\text { Cumulative percent finer } \\
\qquad(\%)\end{array}$} \\
\hline & & May/June 2003 & May 2005 & October 2006 & April 2008 \\
\hline Sand & 2 & 24.2 & 8.5 & 28.7 & 15.3 \\
\hline Very fine gravel & 4 & 25.1 & 8.6 & 37.6 & 26.8 \\
\hline Coarse gravel & 32 & 58.5 & 32.0 & 66.9 & 72.9 \\
\hline Very coarse gravel & 64 & 80.5 & 57.5 & 82.7 & 87.7 \\
\hline Small cobbles & 128 & 95.7 & 94.2 & 95.9 & 97.7 \\
\hline Large cobbles & 256 & 99.9 & 99.6 & 99.8 & 99.9 \\
\hline
\end{tabular}


The data in table 17 show that the majority of particle sizes in the Minebank Run study reach fell between fine gravel and small cobbles for all composite pebble counts both before and after restoration of the stream channel. The analysis also indicates considerable variability in the percentages of sand in the study reach over time. Restoration of the stream channel produced a much coarser channel bed because of large gravel and small cobbles that were placed on the bed. This is shown by the reduction in sand percentages in May 2005. The percentages of sand in October 2006 and April 2008 were elevated in comparison to May 2005, but alternated in relative magnitude over time as the stream channel began its natural response to the restoration. The increase in sand percentages in October 2006 and considerable decrease in April 2008 are indicative of alternating periods of storage and transport of fine bed material in the study reach over time.

From figure 27, the d50 for the study reach ranged from $20.5 \mathrm{~mm}$ (coarse gravel) in May-June 2003 to $53 \mathrm{~mm}$ (very coarse gravel) just after restoration of the stream channel in May 2005. The d50 for the study reach was found to be $11 \mathrm{~mm}$ in October 2006 and $13 \mathrm{~mm}$ in April 2008, which falls within the range of medium gravel. This analysis indicates that despite restoration of the stream channel, sources of fine sediment still exist in the watershed. The abundance of relatively small bed material sizes in combination with the flashy streamflow from urban and suburban runoff likely contributes to the considerable changes in grain-size distributions that have been observed over time (Doheny and others, 2006; Doheny and others, 2007).

The grain-size distributions that were developed from pebble count data collected in May 2002 and May-June 2003 were compared to distributions from pebble count data collected in May 2005, October 2006, and April 2008 at the three groundwater transect locations, which correspond to permanent cross sections $\mathrm{Ee}, \mathrm{Ff}$, and $\mathrm{Gg}$, respectively. Grain-size distributions at these locations for 2002 through 2008 are shown in figures 28-30. An overall shift to larger grain-size distributions, or coarsening, can be seen at all three locations between May 2002 and May-June 2003 that was largely due to changes in percentages and distribution of gravel on the surface of the channel bed (Doheny and others, 2007). Considerable coarsening of the channel bed also is evident at all three cross sections in April 2005 as a result of the restoration work. In October 2006, all three cross sections showed considerable fining of the bed material throughout nearly the full range of particle sizes. In April 2008, cross section Ee indicated coarsening again, whereas cross section Ff indicated continued fining. In April 2008, cross section Gg indicated a combination of coarsening of particle sizes less than $10 \mathrm{~mm}$, and continued fining of particle sizes greater than $10 \mathrm{~mm}$, which resulted in an equivalent $\mathrm{d} 50$ of $11 \mathrm{~mm}$ for both October 2006 and April 2008. These results further support the conclusion that different sections of the study reach began alternating between continued fining and coarsening after an initial post-restoration adjustment period of considerable fining of the channel bed.

\section{Net Changes in Channel Bed Elevation}

Net changes in channel bed elevation were monitored in selected locations of the study reach by use of stream piezometers that had been installed for monitoring shallow groundwater under the channel bed. The locations of these piezometers correspond closely to the locations of cross sections Ee, Ff, and Gg (Doheny and others, 2006; Doheny and others, 2007). Bed elevations were determined by measuring the distance between the top of the piezometer and the channel bed, and subtracting the distance to the channel bed from the known elevation of the measuring point at the top of the piezometer that had been previously surveyed for purposes of monitoring groundwater levels. Bed elevations were initially tracked between December 2002 and July 2004, prior to the stream channel being restored, and again between September 2005 and October 2008, after the stream channel was restored. Graphs indicating the net changes in bed elevation during the pre- and post-restoration periods at these three locations are shown in figures $31-33$.

\section{Cross Section Ee}

During the pre-restoration phase of the monitoring that occurred between January 2003 and July 2004, rapid aggradation and degradation of the channel bed at cross section Ee was evident (Doheny and others, 2007). Analysis of pre-restoration data indicated that volumes of sediment were gradually being stored in this section of the stream channel, and then rapidly transported downstream by flows from large storm events.

When the stream channel was restored during 2004 and early 2005 , the channel in this reach was moved approximately $70 \mathrm{ft}$ from its original location and realigned with a reduced sinuosity. The original stream channel became an oxbow that was cut off from the restored stream channel, but acted as a catchment for storm runoff from the north side of the stream valley.

The restored stream channel had an initial bed elevation in September 2005 that was approximately $2.5 \mathrm{ft}$ higher than the last measured bed elevation prior to restoration in July 2004 (fig. 31). The measured bed elevations varied by approximately $0.40 \mathrm{ft}$ between September 2005 and June 2006, when a large storm event increased the bed elevation by over 0.70 $\mathrm{ft}$. Between June 2006 and September 2008, the bed elevation varied within an approximate range of $0.25 \mathrm{ft}$, with some alternating periods of aggradation and degradation over time.

The data indicate that in this location, the restored stream channel eventually reached a point of dynamic equilibrium after some vertical adjustments during the initial post-construction period between September 2005 and June 2006. However, the vertical adjustments in bed elevation were considerably less than those that were evident during the prerestoration phase of the monitoring, when the data indicated that the stream channel was undergoing alternating periods of extreme sediment storage and erosion at this location (Doheny and others, 2007). 


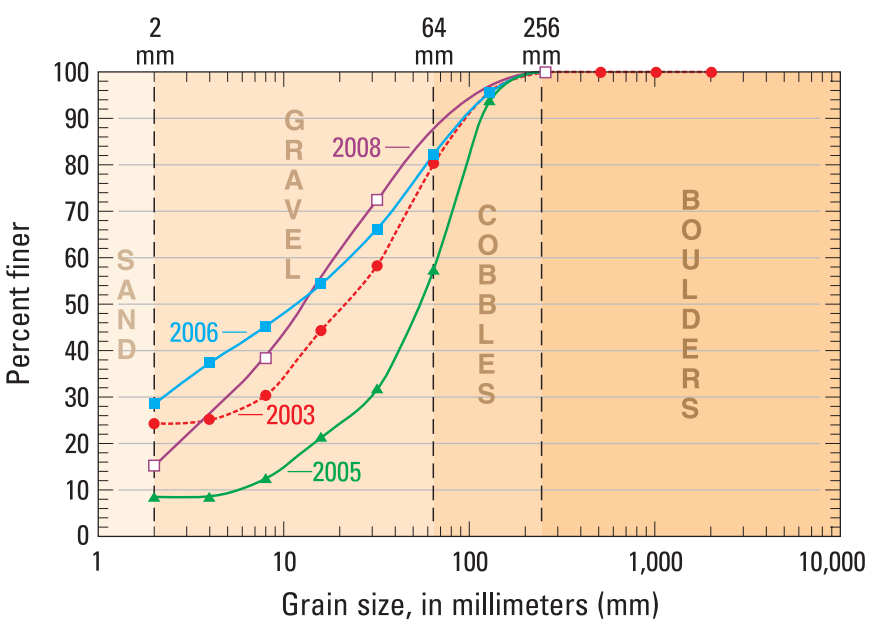

EXPLANATION

$$
\begin{array}{ll}
\bullet-\cdots \text { Pre-restoration (2003) } & \square \text { Post-restoration (2006) } \\
\longrightarrow \text { Post-restoration (2005) } & \square \text { Post-restoration (2008) }
\end{array}
$$

Figure 27. Comparison of composite pebble counts for Minebank Run study reach above Sherwood Bridge before and after channel restoration, 2003 through 2008.

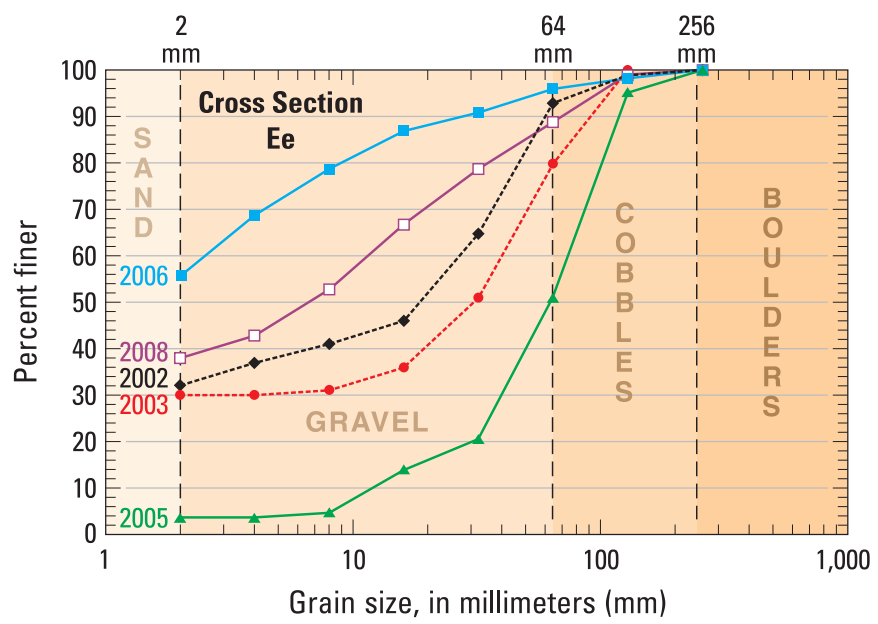

EXPLANATION

$$
\begin{aligned}
& \leftrightarrow \text { Pre-restoration (2002) } \longleftrightarrow \text { Post-restoration (2005) } \\
& \leftrightarrow \text { Pre-restoration (2003) } \because \text { Post-restoration (2006) } \\
& \square \text { Post-restoration (2008) }
\end{aligned}
$$

Figure 28. Comparison of particle-size distributions at cross section Ee, 2002 through 2008.

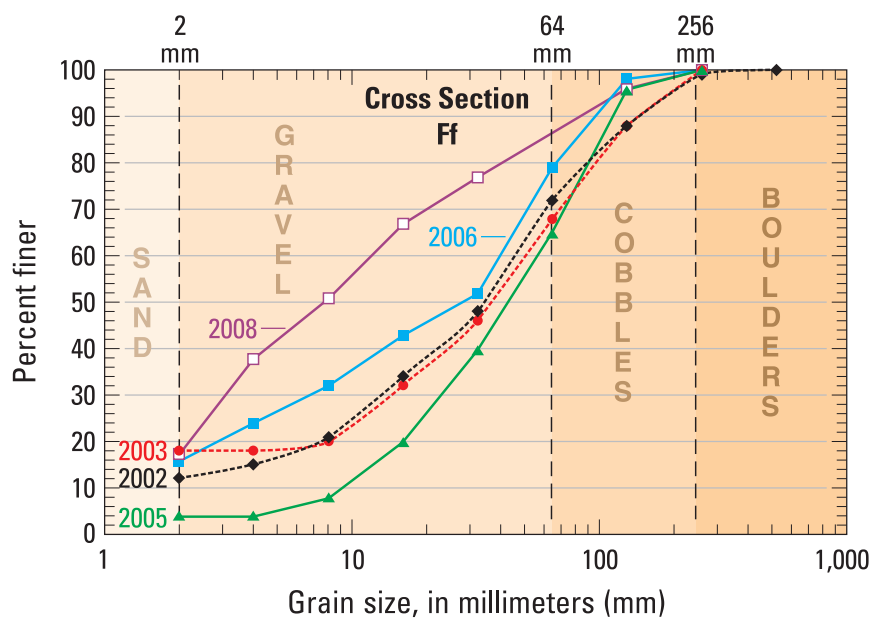

\section{EXPLANATION}

$$
\begin{array}{ll}
\leftrightarrow \text { Pre-restoration (2002) } & \longrightarrow \text { Post-restoration (2005) } \\
\leftrightarrow \text { Pre-restoration (2003) } & \square \text { Post-restoration (2006) } \\
& \square \text { Post-restoration (2008) }
\end{array}
$$

Figure 29. Comparison of particle-size distributions at cross section $\mathrm{Ff}, 2002$ through 2008.

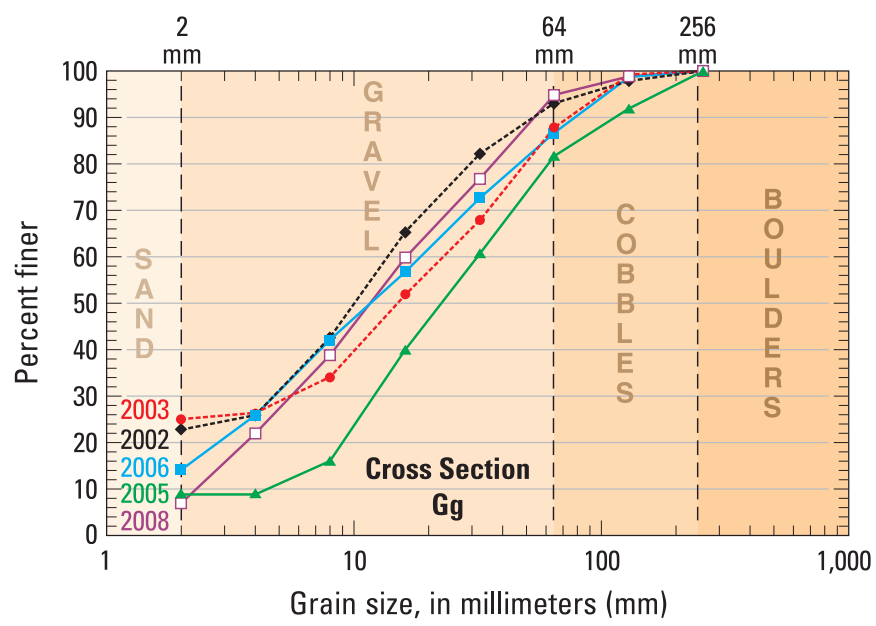

\section{EXPLANATION}

$$
\begin{aligned}
\leftrightarrow \text { Pre-restoration (2002) } & \longrightarrow \text { Post-restoration (2005) } \\
\leftrightarrow \text { Pre-restoration (2003) } & \because \text { Post-restoration (2006) } \\
& \square \text { Post-restoration (2008) }
\end{aligned}
$$

Figure 30. Comparison of particle-size distributions at cross section $\mathrm{Gg}$, 2002 through 2008. 


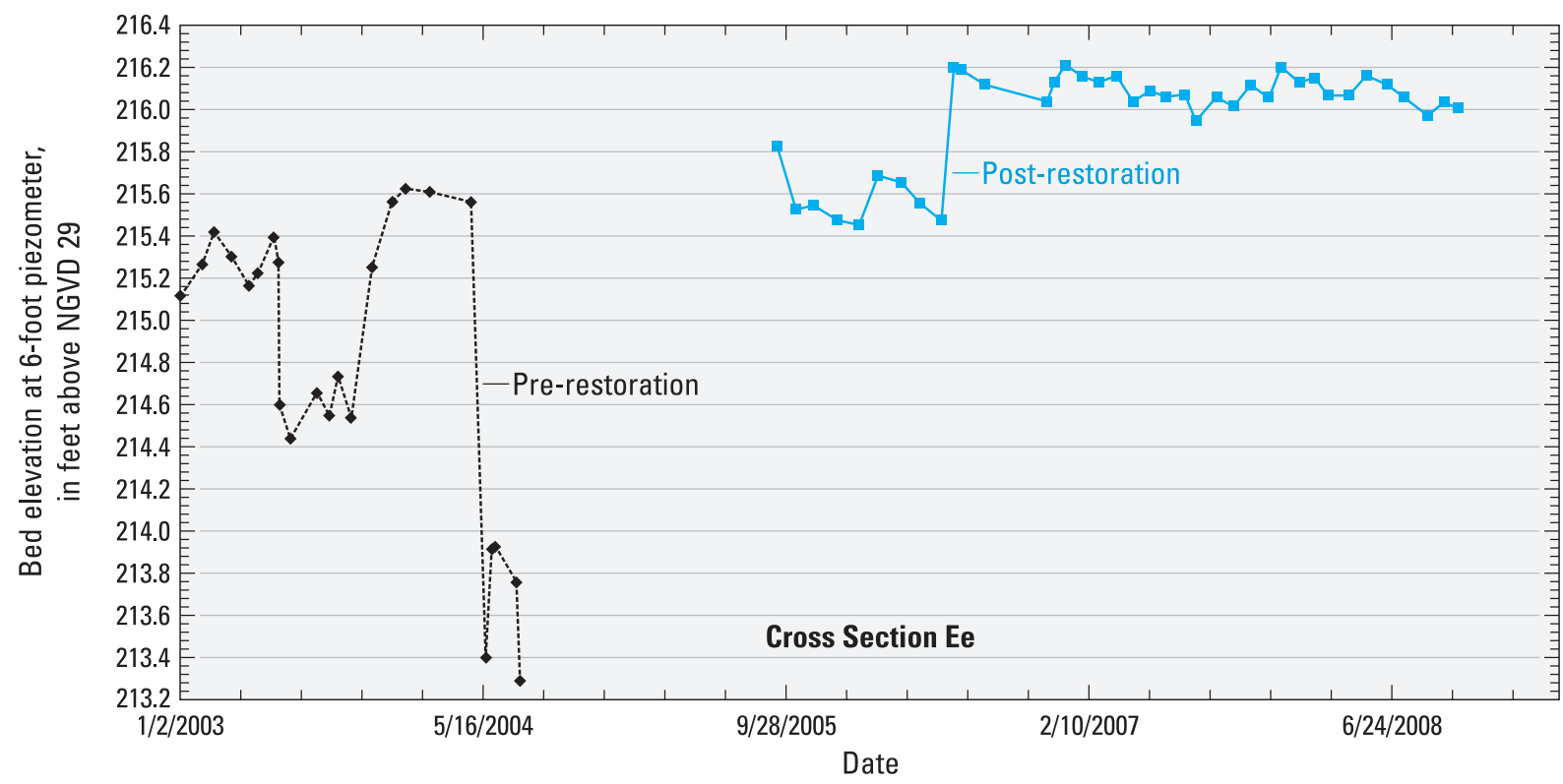

Figure 31. Net changes in bed elevation over time at cross section Ee, January 2, 2003 through 0ctober 7, 2008.

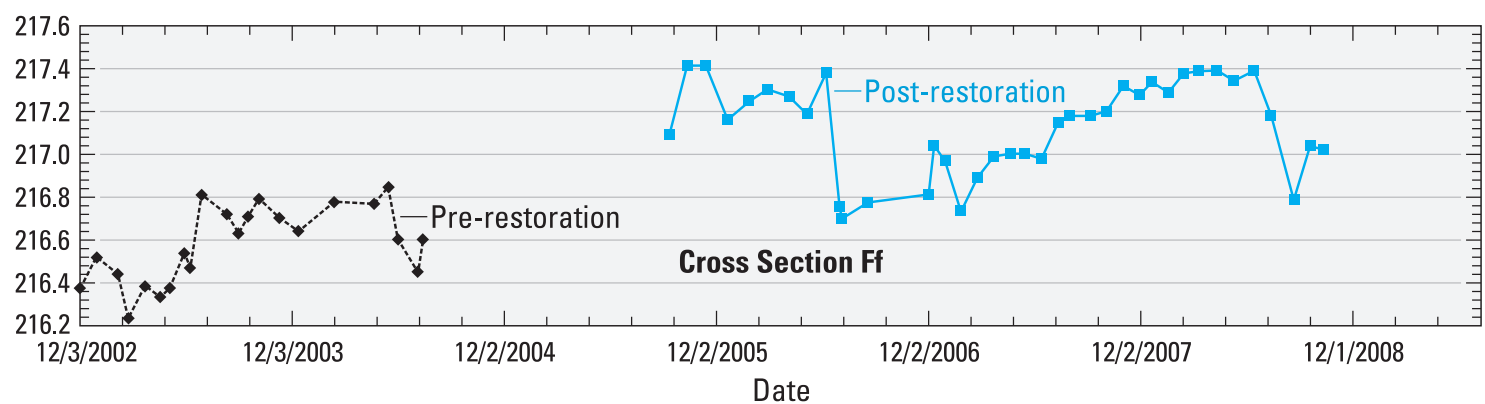

Figure 32. Net changes in bed elevation over time at cross section Ff, December 3, 2002 through 0ctober 7, 2008.

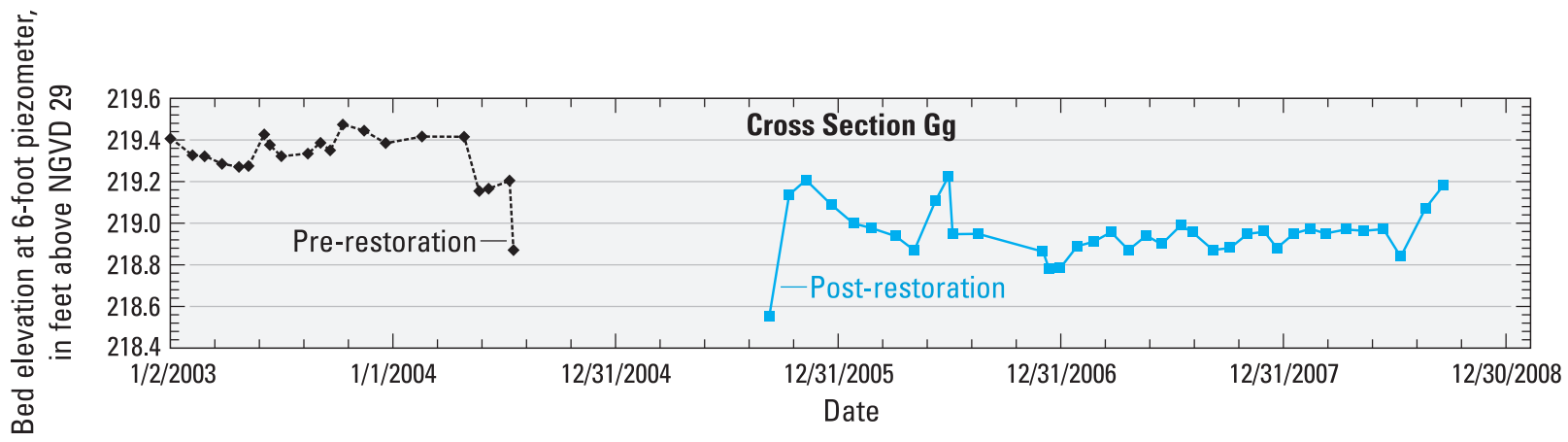

Figure 33. Net changes in bed elevation over time at cross section Gg, January 2, 2003 through September 15, 2008. 


\section{Cross Section Ff}

During the pre-restoration phase of the monitoring that occurred between December 2002 and July 2004, alternating periods of aggradation and degradation of the channel bed were observed at cross section Ff (Doheny and others, 2007). The range of measured bed elevations was only $0.62 \mathrm{ft}$, which was considerably less than that observed at cross section Ee during the pre-restoration phase of the monitoring.

When the stream channel was restored during 2004 and early 2005 , the channel in this reach was armored with riprap along the left bank to prevent lateral erosion in the vicinity of a sanitary sewer pipe that parallels the stream in this location. In addition, woody vegetation was planted along the right bank to provide more natural erosion protection. Also, a rock vein structure was installed in the stream channel a short distance downstream of the cross section, which created a new control point in this location. The alignment of the stream channel was not altered much in this location, but the ability of the channel to adjust itself laterally was reduced considerably.

As with cross section Ee, measurements of bed elevation at cross section Ff indicated some considerable vertical adjustment between September 2005 and July 2006 (fig. 32). During this period, the maximum range of bed elevations measured at cross section Ff was $0.72 \mathrm{ft}$. Between January 2007 and June 2008, the measurements also indicate a lengthy period of net aggradation where the bed elevation increased by about 0.67 feet. This was followed by a fairly rapid decrease in the bed elevation of $0.61 \mathrm{ft}$ during July and August of 2008, and the beginning of a new cycle of aggradation that began in September 2008, when the bed elevation increased by $0.26 \mathrm{ft}$.

Overall, the post-restoration data indicated an alternating pattern of sediment storage with some instances of fairly rapid erosion over time. This was similar to the pattern observed during the pre-restoration monitoring period, but with larger extremes and more rapid changes in erosion over time. The reduction of lateral erosion in the reach caused by the introduction of the riprap and woody vegetation along the banks could be causing additional erosive energy to be directed toward the channel bed, resulting in more extremes and rapid erosion. The data also indicate that this reach has the ability to store larger volumes of sediment for longer periods of time than in its pre-restoration state, possibly due to the grade control introduced downstream of the section when the rock vein was constructed. Overall, the channel bed showed slight degradation during the post-restoration period, with a bed elevation that was generally higher than in the pre-restoration phase of the monitoring that was completed in July 2004.

\section{Cross Section Gg}

Relatively small changes in bed elevation were observed at cross section $\mathrm{Gg}$ during the majority of the pre-restoration monitoring period between January 2003 and July 2004 (Doheny and others, 2007). The analysis indicated some pulsing of sediment through the cross section, but with considerably smaller amounts of sediment storage in this location than at either cross section Ee or Ff (Doheny and others, 2007). The measurements of bed elevation also indicated some increased degradation and instability of the channel bed during the final 3 months of the pre-restoration monitoring period between May and July 2004 (Doheny and others, 2007).

When the stream channel was restored during 2004 and early 2005, this section of the channel was not physically disturbed by the construction work. All geomorphic changes observed in this cross section were most likely due to restoration activities and features that were implemented in the upstream or downstream vicinity of this reach.

After the restoration work was completed and geomorphic monitoring resumed in the study reach in September 2005 , the bed elevation in this cross section was about $0.30 \mathrm{ft}$ lower than the last measured bed elevation prior to restoration (fig. 33). The bed elevation varied within a range of $0.66 \mathrm{ft}$ between September 2005 and December 2006, with the most rapid changes occurring during storm events in October 2005 and June 2006. Between December 2006 and June 2008, the bed elevation varied within a range of $0.21 \mathrm{ft}$, with some alternating periods of slight aggradation and degradation over time.

The data indicate that at cross section Gg, the stream channel eventually reached a point of dynamic equilibrium during the post-restoration period, but after a period of considerable vertical adjustment in bed elevation between September 2005 and December 2006. The data also indicate that this reach continues to store lesser amounts of sediment over time than either cross section Ee or Ff. Overall, the channel bed aggraded during the period of post-restoration monitoring, but with bed elevations that were generally lower than in the pre-restoration phase of the monitoring that was completed in July 2004.

\section{Study Reach Summary}

Overall, the post-restoration data on measured bed elevations indicate that cross section Ee, which was one of the most geomorphically unstable locations in the study reach prior to restoration, is less prone to the rapid and extreme changes in bed elevation that were observed prior to restoration. Possible causes for this include: (1) the reduction in channel sinuosity and realignment of the stream channel in this area, (2) the reconstruction of the channel banks that allows runoff from storms to spill out of the stream channel and onto the flood plain in this reach, and (3) the oxbow that was created from the old channel that now acts as a catchment for some of the storm runoff in this location.

The data also indicate that cross section $\mathrm{Ff}$ is more prone to lengthy periods of sediment storage with rapid removal of stored sediment, possibly due to the restoration features that were implemented in the vicinity of this cross section to place more control on the horizontal and vertical adjustments of the stream channel. As in the pre-restoration phase of the monitoring, the data from cross section $\mathrm{Gg}$ indicate periods of relative stability of the channel bed, but also a few periods of 
rapid vertical changes in bed elevation, and relatively smaller amounts of net storage of sediment than at cross sections Ee and Ff. All three cross sections appear to have undergone a period of considerable vertical adjustment for approximately 9 to 15 months after the stream restoration was completed and monitoring was resumed.

\section{Shear Stress Analysis}

Boundary shear stress is the force that flowing water imposes on the channel bed and banks, which is the natural boundary of a stream channel. This quantity was first defined by Shields (1936), and was computed for peak discharges associated with 21 storms during the pre-restoration period (November 2001 through September 2004) by Doheny and others (2007). The reach used for these computations included a longitudinal distance of approximately $180 \mathrm{ft}$, from the location of the continuous-record streamgage (station 0158397967) to station 0158397968 , located just upstream of cross section Gg. The results of those computations indicated that most of these pre-restoration events were characterized by both boundary shear stresses and mean peak-discharge velocities that were larger than those noted by Rosgen (1996) for various non-urban stream types. The slope of the best-fit line between the boundary shear stress and mean velocity at peak discharge for these 21 storms discharges at Minebank Run was flatter than the slopes defined by Rosgen (1996) for all defined non-urban stream types. The physical interpretation of these facts was that small changes in mean flow velocity in Minebank Run resulted in relatively large changes in boundary shear stress, and correspondingly rapid increases in the force applied to the stream-channel boundaries with an associated increase in the stream's ability to transport sediment.

After restoration construction and activities had moved downstream from cross section Gg in November 2004, 11 storm discharges occurred for which the necessary crosssection geometry and water-surface slope data were available to compute boundary shear stress. The boundary shear stresses at peak discharge for these 11 events were computed. Data variables and associated boundary shear stress values for the 11 post-restoration storm events are shown in table 18 . Boundary shear stress also was plotted against the mean velocity at peak discharge for these 11 storm events and compared to pre-restoration conditions (fig. 34). As shown in figure 34, the magnitudes of the boundary shear stresses for post-restoration events are comparable to those from the pre-restoration period, however, the mean flow velocities at peak discharge are somewhat smaller than those during the pre-restoration period. Also, the slope of the best-fit line showing the relation between boundary shear stress and mean velocity is nearly 50 percent greater than that for the pre-restoration period. This indicates that a larger increase in mean velocity is required to apply a given increase in force on the channel bed and bank materials and, in turn, for initiation of sediment transport. The $\mathrm{R}^{2}$ of 0.64 indicates that the strength of the relation is lower in the post-restoration period. This may be caused by the channel adjustments that were occurring, particularly in the early stages, after restoration work was completed.

As was previously discussed, the magnitude, intensity, and distribution of the precipitation events in the pre- and post-restoration periods are generally comparable. Therefore, it is reasonable to conclude that the change in the relation noted above is a result of changes introduced to the stream channel by the restoration work. Specifically, it is reasonable to conclude that the stabilization (bed-elevation control points) and realignment of the channel, including the oxbow cutoffs designed to increase channel conveyance at peak flows, have acted in conjunction to decrease peak-flow velocities.

\section{Net Changes in Sediment Volume}

Net changes in sediment volume that was stored in or removed from the study reach between cross-sectional surveys were estimated during both the pre- and post-restoration monitoring periods. Differences in cross-sectional area at each of the nine permanent cross sections were determined at channel-full elevation between each successive survey. A net increase in cross-sectional area was interpreted as degradation in the cross section. A net decrease in cross-sectional area was interpreted as aggradation in the cross section. The stream length between each cross section was used to compute a difference in volume for each cross section by (1) applying half the stream length to the upstream cross section and half to the downstream cross section, and (2) multiplying the difference in cross-sectional area at each cross section between surveys by the appropriate stream length to determine changes in volume in cubic feet for each reach segment associated with each of the cross sections. The changes in volume between crosssectional surveys for reach segments associated with each permanent cross section in the Minebank Run study reach are presented in table 19.

Degradation in the study reach was evident during the pre-restoration phase of the monitoring, with considerably greater degradation during the period between December 2002 and July 2003 (table 19). The period between February 2004 and April 2005 was not included in the investigation because any changes occurring during that period were most likely due to physical reconstruction of the stream channel that occurred between June 2004 and February 2005, and not natural aggradation or degradation caused by natural geomorphic processes. The period between April 2005 and December 2005 indicated degradation in the study reach that was most likely due to initial geomorphic adjustment of the stream channel after completion of the restoration work in early 2005 . Between December 2005 and August 2007, the results indicate overall aggradation within the study reach. Between August 2007 and April 2008, the results indicate overall degradation in the study reach.

To estimate the volume of sediment associated with the changes in volume between cross-sectional surveys that 
Table 18. Data variables and boundary shear stress computations for 11 storm runoff events in the Minebank Run study reach, December 2004 through August 2008.

[ft $\mathrm{ft}^{3} / \mathrm{s}$, cubic feet per second; $\mathrm{ft}^{2}$, square feet; $\mathrm{ft} / \mathrm{s}$, feet per second; $\mathrm{ft}$, feet; $\mathrm{ft} / \mathrm{ft}$, feet per foot; $\mathrm{lb} / \mathrm{ft}^{2}$, pound per square foot]

\begin{tabular}{|c|c|c|c|c|c|c|}
\hline $\begin{array}{c}\text { Date of storm } \\
\text { event }\end{array}$ & $\begin{array}{l}\text { Peak discharge } \\
\qquad\left(\mathrm{ft}^{3} / \mathrm{s}\right)\end{array}$ & $\begin{array}{c}\text { Cross-sectional } \\
\text { area } \\
\left(\mathrm{ft}^{2}\right)\end{array}$ & $\begin{array}{c}\text { Mean velocity } \\
\text { (ft/s) }\end{array}$ & $\begin{array}{l}\text { Hydraulic radius } \\
\text { (ft) }\end{array}$ & $\begin{array}{c}\text { Water-surface } \\
\text { slope } \\
\text { (ft/ft) }\end{array}$ & $\begin{array}{c}\text { Boundary shear } \\
\text { stress } \\
\left(\mathrm{lb} / \mathrm{ft}^{2}\right)\end{array}$ \\
\hline $12 / 23 / 2004$ & 304 & 101.7 & 2.99 & 2.23 & 0.0072 & 1.00 \\
\hline $1 / 14 / 2005$ & 224 & 80.3 & 2.79 & 2.23 & 0.0065 & 0.90 \\
\hline $3 / 28 / 2005$ & 227 & 81.0 & 2.80 & 2.24 & 0.0066 & 0.92 \\
\hline $7 / 8 / 2005$ & 231 & 82.1 & 2.81 & 2.26 & 0.0067 & 0.94 \\
\hline $6 / 3 / 2006$ & 770 & 171.8 & 4.48 & 3.24 & 0.0082 & 1.66 \\
\hline $6 / 25 / 2006$ & 1,400 & 204.1 & 6.86 & 3.58 & 0.0095 & 2.12 \\
\hline $7 / 6 / 2006$ & 370 & 109.6 & 3.38 & 2.29 & 0.0119 & 1.70 \\
\hline $11 / 16 / 2006$ & 527 & 126.1 & 4.18 & 2.60 & 0.0069 & 1.12 \\
\hline
\end{tabular}

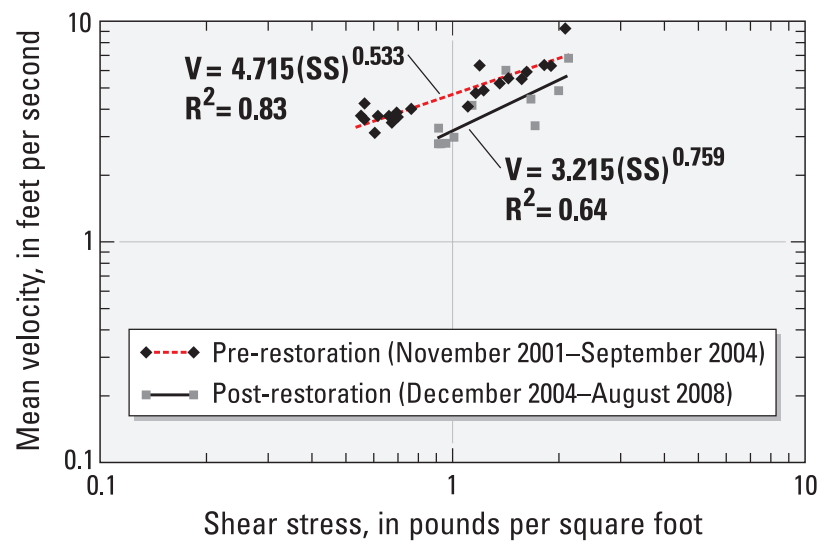

Figure 34. Boundary shear stress versus mean velocity at the peak discharge during storm events in the Minebank Run study reach, November 2001 through September 2004, and December 2004 through August 2008.

were presented in table 19, the porosity of the sediment in the stream channel must be considered. Typical porosities of gravel-bed streams and rivers range from 21 to 34 percent (Haschenburger and Roest, 2008). Applying this range of porosity to the computed changes in volume for the study reach between cross-sectional surveys allowed the volume of pore space to be computed and subtracted out, with the remainder being the volume of sediment removed or stored in the reach. To estimate a rate of change in sediment volume over time, the average number of days between cross-sectional surveys was determined, and a bulk density for natural gravel with sand of $120 \mathrm{lb} / \mathrm{ft}^{3}$ (pounds per cubic foot) was used to convert the sediment volume estimates to a rate that is presented in tons per year. Estimates of sediment volume and the rate of change in sediment volume stored or removed from the Minebank Run study reach between December 2002 and April 2008 are presented in table 20.

Sediment was removed from the study reach prior to restoration with the largest sediment volume and rate of removal occurring during the period of December 2002 to July 2003 (table 20). The storm and flood of June 12, 2003, which produced a peak discharge of $1,390 \mathrm{ft}^{3} / \mathrm{s}$ and is the second largest peak for the period of record at the continuousrecord streamgage, is a likely factor in the volume of sediment removed from the study reach during this period. During the post-restoration period, the data in table 20 indicate an alternating pattern of sediment removal and storage, with the largest sediment volume and rate of removal occurring between April 2005 and December 2005. This period was just after completion of the restoration work and the stream channel was likely in the early stages of geomorphic adjustment and response to the physical disturbances that were applied during the restoration. The largest volumes and rates of sediment storage occurred during December 2005 to September 2006. The storm and flood of June 25, 2006, which produced a peak discharge of $1,400 \mathrm{ft}^{3} / \mathrm{s}$ and is the peak of record at the continuous-record streamgage, is a likely factor in the volume of sediment stored in the study reach during this period. The computations for September 2006 to August 2007 indicate additional storage of sediment, but at a considerably reduced volume and rate than the previous period. From August 2007 to April 2008, the computations indicate overall removal of sediment from the study reach, but with volumes and rates that were reduced from the initial period of geomorphic adjustment and response to the restoration work between April 2005 and December 2005. 
Table 19. Changes in volume, in cubic feet, between cross-sectional surveys for reach segments associated with each permanent cross section, Minebank Run study reach, December 2002 through April 2008.

[-, degradation in reach segment; +, aggradation in reach segment; ft, feet $]$

\begin{tabular}{|c|c|c|c|c|c|c|}
\hline Cross section & $\begin{array}{c}\text { December } 2002 \text { - } \\
\text { July } 2003\end{array}$ & $\begin{array}{l}\text { July } 2003 \text { - } \\
\text { February } 2004\end{array}$ & $\begin{array}{c}\text { April 2005 - } \\
\text { December } 2005\end{array}$ & $\begin{array}{c}\text { December } 2005 \text { - } \\
\text { September } 2006\end{array}$ & $\begin{array}{c}\text { September } 2006 \text { - } \\
\text { August } 2007\end{array}$ & $\begin{array}{c}\text { August } 2007 \text { - } \\
\text { April } 2008\end{array}$ \\
\hline Aa & -210.9 & -684.5 & +225.0 & -213.0 & -78.0 & +81.0 \\
\hline $\mathbf{B b}$ & $+2,236.3$ & -10.7 & $-1,228.8$ & +297.6 & $+1,056.0$ & $-1,440.0$ \\
\hline $\mathrm{Cc}$ & $-1,580.8$ & +53.2 & -411.0 & -301.4 & +150.7 & +465.8 \\
\hline Dd & $-1,302.4$ & $-1,742.4$ & -915.0 & +525.0 & +210.0 & -645.0 \\
\hline Gg & $-1,700.4$ & -249.6 & $-1,643.0$ & $+3,131.0$ & -31.0 & -403.0 \\
\hline Hh & $-1,391.2$ & +131.6 & $-1,823.6$ & $+3,120.8$ & +470.0 & -827.2 \\
\hline Ii & $-1,242.0$ & $-2,192.4$ & +432.0 & +378.0 & -10.8 & +32.4 \\
\hline TOTAL & $-9,340.9$ & $-2,240.1$ & $-4,792.4$ & $+6,373.0$ & $+2,540.7$ & $-3,926.0$ \\
\hline
\end{tabular}

Note: Total reach length was 1,315 ft between December 2002 and February 2004, and 1,264 ft between April 2005 and April 2008.

Table 20. Estimates of sediment volume and rate of change in sediment volume stored or removed from the Minebank Run study reach, December 2002 through April 2008.

[n, porosity; \%, percent; -, sediment volume removed from study reach; +, sediment volume stored in study reach; $\mathrm{ft}^{3}$, cubic feet; $\mathrm{ft}$, feet]

\begin{tabular}{|c|c|c|c|c|c|}
\hline $\begin{array}{l}\text { Time period between } \\
\text { cross-sectional surveys }\end{array}$ & $\begin{array}{l}\text { Minimum } \\
\text { sediment } \\
\text { volume } \\
\left(\mathrm{ft}^{3}\right) \\
(\mathrm{n}=34 \%)\end{array}$ & $\begin{array}{c}\text { Mean } \\
\text { sediment } \\
\text { volume } \\
\left(\mathrm{ft}^{3}\right) \\
(\mathrm{n}=27.5 \%)\end{array}$ & $\begin{array}{l}\text { Maximum } \\
\text { sediment } \\
\text { volume } \\
\left(\mathrm{ft}^{3}\right) \\
(\mathrm{n}=21 \%)\end{array}$ & $\begin{array}{l}\text { Average } \\
\text { number } \\
\text { of days } \\
\text { between } \\
\text { surveys }\end{array}$ & $\begin{array}{l}\text { Rate of change in sediment } \\
\text { volume stored or removed } \\
\text { from study reach } \\
\text { (tons/year) }\end{array}$ \\
\hline December 2002-July 2003 & $-6,165.0$ & $-6,772.2$ & $-7,379.3$ & 214 & -631.0 to -956.0 \\
\hline July 2003-February 2004 & $-1,478.5$ & $-1,624.3$ & $-1,770.0$ & 205 & -158.0 to -189.1 \\
\hline April 2005-December 2005 & $-3,163.0$ & $-3,474.5$ & $-3,786.0$ & 232 & -298.6 to -357.4 \\
\hline December 2005-September 2006 & $+4,206.0$ & $+4,620.5$ & $+5,035.0$ & 293 & +314.4 to +376.3 \\
\hline September 2006-August 2007 & $+1,677.0$ & $+1,842.0$ & $+2,007.0$ & 342 & +106.8 to +128.5 \\
\hline August 2007-April 2008 & $-2,591.0$ & $-2,846.5$ & $-3,102.0$ & 219 & -259.1 to -310.2 \\
\hline
\end{tabular}

Note: Total reach length was 1,315 ft between December 2002 and February 2004, and 1,264 ft between April 2005 and April 2008.

\section{Comparison of 1960s Bed Elevations and Longitudinal Profile to 2002-08 Study Reach Conditions}

A generalized channel bed profile of the Minebank Run study reach from the early 1960 s was located within a set of engineering plans that was prepared in 1966 for the design of a sanitary sewer line that was installed along the Minebank Run stream channel and flood plain (Matz, Childs, and Associates, Inc., 1966). Analysis of the bed profile from the plans indicated that the slope of the channel bed in the early 1960s was 0.0101 , or about 1 percent. This slope was exactly the same as the slope based on the surveyed longitudinal profile from
2002, and slightly greater than the slope found in subsequent surveys between 2003 and 2008 (table 9).

From the plans, the top of the sewer pipe was designed to be a minimum of $1.5 \mathrm{ft}$ and a maximum of $4.1 \mathrm{ft}$ below the elevation of the channel bed in the study reach. On average, there was approximately $2.5 \mathrm{ft}$ between the channel bed elevation and the top of the sewer pipe (Matz, Childs, and Associates, Inc., 1966). Longitudinal surveys of the same reach that were conducted between 2002 and 2004 indicated exposure of the pipe in some sections of the channel, and channel bed elevations that ranged from $0.7 \mathrm{ft}$ to nearly 3.1 $\mathrm{ft}$ below the top of the sewer pipe. This indicates that over approximately 40 years between the early 1960s and 2002, the channel bed may have degraded by approximately $3.2 \mathrm{ft}$, and 
by as much as $5.6 \mathrm{ft}$ in some locations, possibly due to local scour in the vicinity of the sewer pipe.

The generalized channel bed profile from the early 1960s was plotted for the study reach area and compared to channel bed elevations that were surveyed in 2002 during the prerestoration period (fig. 35). Generalized channel bed profiles from surveys conducted just after restoration in 2005 and 3 years after restoration in 2008 are also presented for comparison (fig. 36). All profiles indicated consistently lower channel bed elevations in 2002, 2005, and 2008 than in the early 1960s. Bed degradation from land-use change in the watershed is the likely cause of the differences observed between the early 1960 s and 2002. Differences throughout the study reach ranged from $1.3 \mathrm{ft}$ to $5.0 \mathrm{ft}$ based on comparison of elevations at approximately equivalent locations along the profile. The 2005 profile indicates that the channel bed was elevated in most sections of the study reach after restoration, but lower between stations 3,600 ft and 3,850 ft, which includes the area at the continuous-record streamgage and well transect 3 (figs.

$14,35,36)$. This area of the stream channel was not physically altered by the restoration work and appears to have responded naturally. Bed elevations in the study reach ranged from $0.8 \mathrm{ft}$ to $4.8 \mathrm{ft}$ lower in 2005 than the early 1960s bed elevations at approximately equivalent locations along the channel profile. The 2008 profile quantifies the natural adjustments to the stream channel that occurred after restoration, which included alternating areas of elevated and lower bed elevations when compared to the newly restored profile from 2005. In 2008, bed elevations ranged from $0.8 \mathrm{ft}$ to $4.1 \mathrm{ft}$ lower than the early 1960 s bed elevations at approximately equivalent locations along the channel profile.

By scaling distances using the early 1960s channel bed profile, it was determined that the channel bed elevation at cross section Hh (station 3678.0) was approximately $223.2 \mathrm{ft}$ NGVD at that point in time. The thalweg elevations that were surveyed between 2002 and 2008 at cross section Hh, and the differences in elevation from those found in the early 1960s are shown in table 21.

The thalweg elevation at cross section Hh is consistently lower than it was in the early 1960s (table 21). With the exception of November 2005, the difference between the surveyed bed elevations and that determined from the early 1960s profile ranged from 3.2 to $3.8 \mathrm{ft}$. The variability in the elevation found in November 2005 could be due to adjustments that the stream channel was undergoing immediately after completion of the restoration work. The range of 3.2 to $3.8 \mathrm{ft}$ above the thalweg elevation at cross section $\mathrm{Hh}$ is fairly consistent with the elevation of a terrace adjacent to the right bank of the channel. This indicates that the channel bed may have been at the elevation of this terrace in the early $1960 \mathrm{~s}$, and over approximately 40 years, the bed has degraded by about 3.2 to $3.8 \mathrm{ft}$. If this feature is, in fact, evidence of the channel bed elevation at that point in time, it is possible that the cross-sectional area of the stream channel prior to the degradation was approximately 150 square feet, and that the cross-sectional area may have increased by as much as 40 to 60 percent in some locations of the study reach.
Bed elevations also were compared in several other locations to determine relative differences in elevation between the early 1960s and the present. For example, the bed elevation at station $4,944 \mathrm{ft}$, which is the lowermost station of the study reach near Sherwood Bridge, was found to be about 4.2 $\mathrm{ft}$ lower in 2002 than in the early $1960 \mathrm{~s}$, about $3.6 \mathrm{ft}$ lower in 2005 , and about $3.1 \mathrm{ft}$ lower in 2008. The differences between 2002,2005 , and 2008 are likely due to the stream restoration, coupled with the net effects of natural post-restoration adjustments to the channel bed from stormflows.

A comparison of bed elevations at the confluence of Minebank Run and Harts Run was possible based on the 2005 longitudinal profile survey and bed elevations from the early 1960s profile. This indicated that the channel bed was about $3.2 \mathrm{ft}$ lower in 2005 than in the early 1960s. Because the prerestoration longitudinal profile surveys were not extended up to the confluence with Harts Run, a direct pre-restoration comparison at this point was not possible. However, based on the early 1960s profile and the 2002 longitudinal profile survey, a comparison of the most upstream point from the 2002 survey was possible. This point was approximately $255 \mathrm{ft}$ downstream of the confluence between Minebank Run and Harts Run, and indicated that the channel bed was approximately $3.0 \mathrm{ft}$ lower in 2002 than in the early 1960s.

While the stream channel has maintained an overall slope of about 1 percent, all comparisons of bed elevations made between the early 1960s and 2002 indicate that the channel bed degraded over time in the Minebank Run study reach within an approximate range of $1.3 \mathrm{ft}$ to $5.0 \mathrm{ft}$, with possible local scour of up to $5.6 \mathrm{ft}$ in locations near the sanitary sewer pipe. In the post-restoration condition, evidence indicates that the channel bed is still about $0.8 \mathrm{ft}$ to $4.8 \mathrm{ft}$ lower than bed elevations from the early 1960s at approximately equivalent locations along the profile.

\section{Data Limitations}

The geomorphic data collected during this study are representative of approximately 6 years in the long-term geomorphic evolution of the stream channel. Data collection over longer periods of time could provide a longer term perspective on the geomorphic form and processes of the stream channel.

Data collected during this study were for purposes of evaluating only the 2004-05 restoration at Minebank Run. Due to the timing of the study, evaluation of geomorphic conditions based on the 1998-99 restoration in the headwater areas of Minebank Run was not possible.

Cross-sectional geometry and hydraulic parameters presented in this report are limited to data collected from 2005 through 2008. Information from the 2002 through 2004 field surveys were not re-published in this report. The reader should refer to Appendix 1 of Doheny and others (2007) to obtain this information.

Longitudinal profiles and cross-sectional characteristics were developed based on data that were collected by use of 


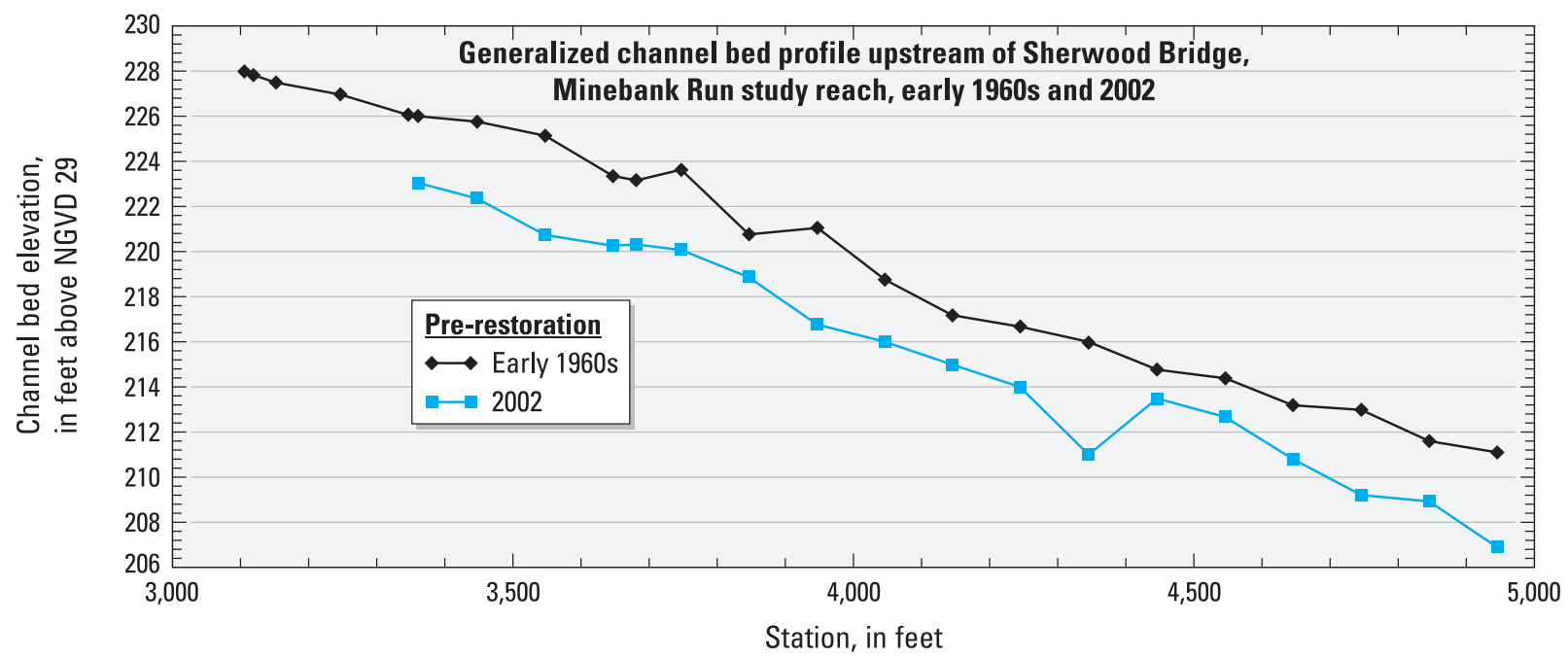

Figure 35. Generalized pre-restoration channel bed profile upstream of Sherwood Bridge, Minebank Run study reach, early 1960s and 2002.

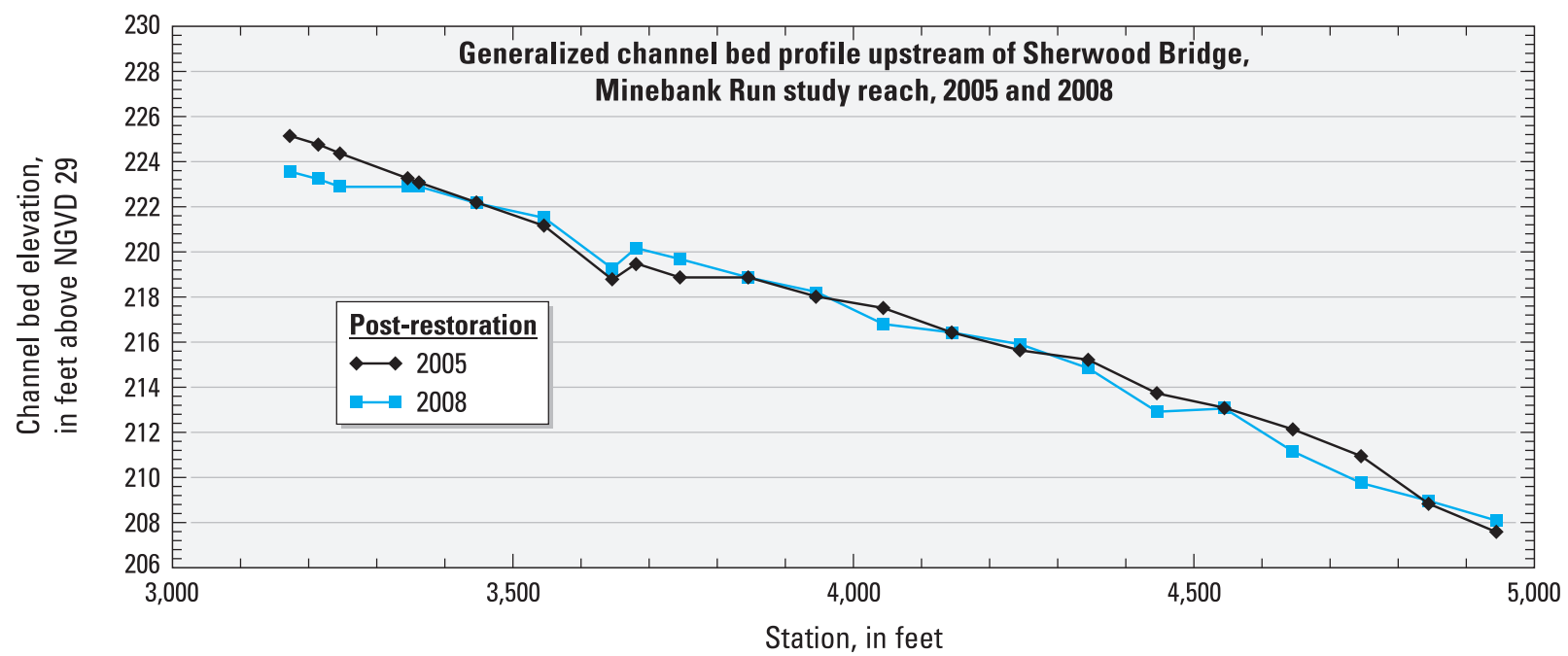

Figure 36. Generalized post-restoration channel bed profile upstream of Sherwood Bridge, Minebank Run study reach, 2005 and 2008.

Table 21. Thalweg elevations at cross section Hh from longitudinal profile surveys between 2002 and 2008 , and corresponding differences from early 1960s channel bed elevation.

[ft, feet; NGVD 29, National Geodetic Vertical Datum of 1929]

\begin{tabular}{|ccc|}
\hline Month and year & $\begin{array}{c}\text { Thalweg elevation at cross section Hh } \\
\text { (ft above NGVD 29) }\end{array}$ & $\begin{array}{c}\text { Difference below early 1960s bed elevation } \\
\text { (ft) }\end{array}$ \\
\hline December 2002 & 219.78 & 3.4 \\
\hline June 2003 & 219.44 & 3.8 \\
\hline January 2004 & 219.75 & 3.5 \\
\hline April 2005 & 219.81 & 3.4 \\
\hline November 2005 & 218.48 & 4.7 \\
\hline September 2006 & 220.02 & 3.2 \\
\hline August 2007 & 220.03 & 3.2 \\
\hline April 2008 & 219.99 & 3.2 \\
\hline
\end{tabular}


conventional leveling techniques. Although permanent monuments were used to identify and re-survey cross sections, there is a degree of difficulty in maintaining the same stations from survey to survey, and conventional leveling can include a small degree of human error in interpreting readings from the survey rod. Due to geomorphic changes in the stream channel over time, there is also a small degree of error in maintaining exact longitudinal stationing from survey to survey.

Pebble count data represent a random sampling of particle sizes from the channel bed. As a result, small differences in particle-size distribution may, in some cases, be explained by random variability of the samples taken from the channel bed.

The geomorphic investigation at Minebank Run did not include any physical measurements of suspended sediment or bedload. The computed changes in sediment volume, as well as rates of change in the volume of sediment stored and removed from the study reach, are based solely on changes observed in between cross-sectional surveys in the study reach over time.

The comparison of 1960 s bed elevations to 2002-08 study reach conditions is considered preliminary and requires more detailed investigation to further confirm the longitudinal stationing for comparing pre- and post-restoration conditions. The bed profile plotted on the engineering plans was not an exact match to the listed scale of 1 in. equals $50 \mathrm{ft}$ (Matz, Childs, and Associates, Inc., 1966). In addition, geomorphic adjustment of the stream channel over time can cause variability in the longitudinal stationing due to intermediate changes in the stream length of the channel between known points on the profile. The longitudinal stationing also was affected by the physical movement of the stream channel during the restoration, which altered the stream length in some locations and could add some possible error to direct comparisons of pre- and post-restoration bed elevations.

\section{Summary and Conclusions}

In October 2001, the U.S. Geological Survey (USGS), the U.S. Environmental Protection Agency (USEPA), and the Cary Institute of Ecosystem Studies (CIES) jointly initiated a study to investigate the effects of stream restoration on stream hydrology, denitrification, and overall water quality in a study reach of Minebank Run near Towson, Maryland. In response to rapid changes in channel geometry and elevations of channel features, as well as the rate of lateral migration of the stream channel observed during the first year of the study, the USGS was also tasked with measuring and documenting the geomorphic changes within the Minebank Run study reach before and after physical restoration.

This report presents a geomorphic analysis of pre- and post-restoration conditions in the study reach of Minebank Run that was based on data collected between water years 2002 and 2008. Data collected included continuous-record streamflow and precipitation; surveyed elevations of the channel bed, water surface, and channel features; surveyed cross sections; pebble counts from the channel bed; measurements of bed elevation over time in selected locations of the study reach; and high-water marks that were retrieved in selected locations of the study reach from storm runoff events in the watershed.

Investigation of precipitation, discharge intensity, time of concentration, flood frequency, and rainfall-runoff relations showed that hydrologic conditions were comparable for the pre- and post-restoration monitoring periods. Flood frequency analysis indicated that the largest peak flows that occurred in the Minebank Run watershed during the monitoring period could represent events of lower probability when compared to a longer peak-flow record in the West Branch Herring Run watershed, which shares a drainage area boundary with Minebank Run.

Comparison of longitudinal profiles over time indicated considerable differences in the distribution and location of riffles, pools, and runs in the study reach between 2002 and 2008. In both the pre-restoration and post-restoration monitoring periods, the analyses indicated that, on average, the stream is maintaining the overall slope of the channel bed and water surface at about 1 percent in the study reach, despite considerable changes in the percentages of riffles, pools, and runs, and changes in the distribution and location of these features in the study reach.

On the basis of analysis of the cross sections in both the pre- and post-restoration monitoring periods, lateral erosion has been reduced considerably with fewer indications of any channel widening. Flood flows now have the ability to contact sections of the overbank area, and also bypass the main channel in small sections of the study reach, which was not possible in the pre-restoration monitoring period. Much of the geomorphic variability displayed in the post-restoration monitoring period is due to aggradation and degradation of the channel bed and shifting of the channel thalweg, instead of channel degradation and widening, and lateral erosion from receding cut banks, which was commonly observed during the pre-restoration monitoring period. Most locations in the study reach continue to indicate alternating patterns of sediment storage and removal over time. At least four of the cross sections indicated reduced variability in cross-sectional area and mean depth between surveys conducted from 2006 through 2008, however. This indicates that the stream channel could be establishing a dynamic equilibrium and a more stable geometry after the initial geomorphic response observed in 2005 and 2006, just after the physical disturbances created by the restoration work.

Analyses of hydraulic-geometry relations of selected channel variables against discharge indicated moderate to strong linear relations for most variables. In the pre-restoration monitoring period, the strongest relation was between crosssectional area and discharge. In the post-restoration monitoring period, the strongest relation was between mean flow velocity and discharge.

Composite particle-size analyses of the channel bed from pebble counts over time indicated that the majority of particle 
sizes in the Minebank Run study reach fell between fine gravel and small cobbles. Median particle diameters found in the study reach were $20.5 \mathrm{~mm}$ (millimeters) in May-June 2003, approximately 1 year prior to restoration of the stream channel, $53.0 \mathrm{~mm}$ in May 2005, just after restoration of the stream channel, $11.0 \mathrm{~mm}$ in October 2006, and $13.0 \mathrm{~mm}$ in April 2008. Sand particles ranged from 8.5 percent to 28.7 percent of the cumulative percent finer, with considerable alternating increases and decreases over time. This indicates that sources of fine sediment, possibly from bank erosion, still exist in the watershed despite restoration of the stream channel. The abundance of relatively small bed material sizes in combination with flashy streamflow from urban and suburban runoff likely contributes to the considerable changes in grain-size distribution and alternating periods of storage and transport of sand and gravel that have been observed in the study reach over time.

Net changes in channel bed elevation measured at selected locations indicated that cross section Ee, which was one of the most geomorphically unstable locations in the study reach prior to restoration, was considerably less prone to rapid and extreme changes in bed elevation after restoration of the stream channel. Cross section Ff was more prone to lengthy periods of sediment storage with rapid removal of stored sediment after restoration, possibly due to the restoration features that were implemented in the vicinity of this cross section to place more control on the horizontal and vertical adjustments of the stream channel. As in the pre-restoration phase of the monitoring, the data from cross section $\mathrm{Gg}$ indicate periods of relative stability of the channel bed, but also with a few periods of rapid vertical changes in bed elevation, and relatively smaller amounts of net storage of sediment than at cross sections Ee and Ff. All three cross sections appear to have undergone a period of considerable vertical adjustment between September 2005 and December 2006 based on postrestoration monitoring.

An analysis of boundary shear stress indicated that the magnitudes of the boundary shear stresses for post-restoration events were comparable to those from the pre-restoration period. However, the mean flow velocities at peak discharge were somewhat smaller than those during the pre-restoration period. The slope of the best-fit line showing the relation between boundary shear stress and mean velocity was nearly 50 percent greater than that for the pre-restoration period. This indicates that during the post-restoration monitoring period, a larger increase in mean velocity was required to apply a given increase in force on the channel bed and bank materials and, in turn, to initiate sediment transport.

An analysis of net changes in sediment volume indicated that sediment was being removed from the study reach prior to restoration, with the largest sediment volume and rate of removal occurring from December 2002 through July 2003. During the post-restoration period, an alternating pattern of sediment removal and storage was observed, with the largest sediment volume and rate of removal occurring from April 2005 through December 2005, just after completion of the restoration work. The largest volumes and rates of sediment storage during the post-restoration period occurred between December 2005 and September 2006. The storm and flood of June 25, 2006, which produced a peak discharge of 1,400 cubic feet per second and is the peak of record at the continuous-record streamgage, is a factor in the volume of sediment stored in the study reach during this period.

A comparison of an early 1960s channel bed profile to 2002-08 study reach conditions indicated that the stream channel has maintained an overall slope of about 1 percent over a period of 40 to 50 years. All comparisons of bed elevations made between the early 1960s and 2002 indicate that the channel bed degraded over time in the Minebank Run study reach within an approximate range of $1.3 \mathrm{ft}$ (feet) to 5.0 $\mathrm{ft}$, with possible local scour of up to $5.6 \mathrm{ft}$ in locations near a sanitary sewer pipe that was exposed within the channel bed. In the post-restoration condition, evidence indicates that the channel bed is still about $0.8 \mathrm{ft}$ to $4.8 \mathrm{ft}$ lower than bed elevations from the early 1960s at approximately equivalent locations along the profile.

\section{Acknowledgments}

The authors would like to thank Kenneth Jewell, Russell Neill, and Brad Scoggins of the U.S. Environmental Protection Agency, National Risk Management Laboratory, Ada, Oklahoma, for extensive assistance in planning and implementation of the study design.

Special thanks are extended to Donald Outen, Karen Ogle, Robert Ryan, Steven Stewart, Candice Croswell, and Nancy Pentz of the Baltimore County Department of Environmental Protection and Sustainability, formerly known as the Baltimore County Department of Environmental Protection and Resource Management, for planning assistance and technical input on the stream-restoration project at Minebank Run.

The authors would like to thank Leo Rebetsky of the Baltimore County Department of Recreation and Parks. As manager of Cromwell Valley Park, Mr. Rebetsky's support, cooperation, and assistance over the years has been critical to successful completion of the project.

Thanks are extended to Roger Starsoneck, formerly of the USGS Maryland-Delaware-D.C. Water Science Center, for extensive assistance with planning and implementation of the study design, and data-collection efforts.

Thanks are also extended to Mastin Mount, Elizabeth Marchand, and Michael Geissel of the USGS MarylandDelaware-D.C. Water Science Center for their assistance with data-collection efforts.

The authors would also like to thank Robert Shedlock, Director of the USGS Maryland-Delaware-D.C. Water Science Center, and Robert W. James, Jr., formerly of the USGS Maryland-Delaware-D.C. Water Science Center, for their assistance and support with technical issues and data interpretation. 


\section{References Cited}

Baltimore County Department of Environmental Protection and Resource Management, 2000, aerial photograph of Minebank Run watershed: Baltimore County, Maryland, 1 sheet, scale $1: 4,800$.

Buchanan, T.J., and Somers, W.P., 1968, Stage measurement at gaging stations: U.S. Geological Survey Techniques of Water-Resources Investigations, book 3, chap. A7, 28 p.

Carter, R.W., and Davidian, J., 1968, General procedures for gaging streams: U.S. Geological Survey Techniques of Water-Resources Investigations, book 3, chap. A6, 13 p.

Crowley, W.P., and Cleaves, E.T., 1974, Geologic map of the Towson quadrangle, Maryland: Maryland Geological Survey, 1 sheet, scale 1:24,000.

Doheny, E.J., Starsoneck, R.J., Mayer, P.M., and Striz, E.A., 2007, Pre-restoration geomorphic characteristics of Minebank Run, Baltimore County, Maryland, 2002-04: U.S. Geological Survey Scientific Investigations Report 2007-5127, 49 p., available online at http://pubs.usgs.gov/ $\operatorname{sir} / 2007 / 5127$.

Doheny, E.J., Starsoneck, R.J., Striz, E.A., and Mayer, P.M., 2006, Watershed characteristics and pre-restoration surfacewater hydrology of Minebank Run, Baltimore County, Maryland, water years 2002-04: U.S. Geological Survey Scientific Investigations Report 2006-5179, 42 p., available online at http://pubs.usgs.gov/sir/2006/5179.

Groffman, P.M., Dorsey, A.M., and Mayer, P.M., 2005, N processing within geomorphic structures in urban streams: Journal of the North American Benthological Society, v. 24, no. 3, p. 613-625.

Harrelson, C.C., Rawlins, C.L., and Potyondy, J.P., 1994, Stream channel reference sites: An illustrated guide to field technique: Fort Collins, Colorado, U.S. Department of Agriculture, Forest Service, Rocky Mountain Forest and Range Experiment Station, General Technical Report RM-245, $61 \mathrm{p}$.

Harrison, M.D., Groffman, P.M., Mayer, P.M., Kaushal, S.S., and Newcomer, T.A., 2011, Denitrification in alluvial wetlands in an urban landscape: Journal of Environmental Quality, v. 40, no. 2, p. 634-646, DOI: 10.2134/ jeq2010.0335.

Haschenburger, J.K., and Roest, P., 2008, Substrate indices as indicators of interstitial pore space in gravel-bed channels: River Research and Applications, v. 25, no. 1, p. 98-105, DOI: 10.1002/rra. 1168.
Interagency Advisory Committee on Water Data, 1982, Guidelines for determining flood flow frequency: Reston, Virginia, Water Resources Council Bulletin 17B, 28 p.

Kaushal, S., Groffman, P.M., Mayer, P.M., Striz, E., and Gold, A., 2008, Effects of stream restoration on denitrification in an urbanizing watershed: Ecological Applications, v. 18, no. 3, p. 789-804.

Leopold, L.B., 1994, A view of the river: Cambridge, Massachusetts, Harvard University Press, 298 p.

Lutz, L., 2006, Minebank Run restoration hits pay dirt in reducing nitrogen loads, in Chesapeake Bay Journal, October 2006, vol. 16, no.7, 4 p., accessed April 27, 2011 at http://www.bayjournal.com/article.cfm? article $=2904$.

Maryland State Climatologist Office, 2011, Baltimore average monthly precipitation (since 1871), accessed May 2, 2011 at http://www.atmos.umd.edu/ climate/Weather/ marylandnormals.htm.

Matz, Childs, and Associates, Inc., 1966, Plan and profile of proposed section III-Gunpowder interceptor and Minebank Run sub-interceptor from Baltimore County Beltway to Glenarm Road: Prepared for the Baltimore County, Maryland Department of Public Works, Contract no. 1040 -S, 11 sheets, horizontal scale: 1 inch $=50$ feet, vertical scale: 1 inch $=5$ feet.

Mayer, P.M., Groffman, P.M., Striz, E., and Kaushal, S.S., 2010, Nitrogen dynamics at the groundwater-surface water interface of a degraded urban stream: Journal of Environmental Quality, v. 39, no. 3, p. 810-823.

Mayer, Paul, Striz, Elise, Shedlock, Robert, Doheny, Edward, and Groffman, Peter, 2003, The effects of ecosystem restoration on nitrogen processing in an urban Mid-Atlantic Piedmont stream, in Renard, K.G., McElroy, S.A., Gburek, W.J., Canfield, H.E., and Scott, R.L., eds., Proceedings of the First Interagency Conference on Research in the Watersheds, Tucson, Arizona, October 27-30, 2003, U.S. Department of Agriculture, Agricultural Research Service, p. 536-541, accessed November 23, 2011 at http://www. tucson.ars.ag.gov/icrw/Proceedings/Mayer.pdf.

Paul, M.J., and Meyer, J.L., 2001, Streams in the urban landscape: Annual Review of Ecology and Systematics, v. 32, p. 333-365.

Rosgen, D.L., 1993, Applied fluvial geomorphology, training manual, river short course: Pagosa Springs, Colorado, Wildland Hydrology, $450 \mathrm{p}$.

Rosgen, D.L., 1996, Applied river morphology: Pagosa Springs, Colorado, Wildland Hydrology, 365 p. 
Shields, A., 1936, Application of similarity principles and turbulence research to bedload movement, translated by W.P. Ott and J.C. Uchelen: Pasadena, California, California Institute of Technology Report No. 167, 43 p.

Striz, E.A., and Mayer, P.M., 2008, Assessment of nearstream ground water-surface water interaction (GSI) of a degraded stream before restoration: U.S. Environmental Protection Agency report EPA/600/R-07/058, 42 p., accessed December 16, 2011 at http://www.epa.gov/nrmrl/ pubs/600.07058/600r07058.pdf.

U.S. Geological Survey, 2009, Water-resources data for the United States, Water Year 2008: U.S. Geological Survey Water-Data Report WDR-US-2008, site 0158397967, accessed May 2, 2011, at http://wdr.water.usgs.gov/wy2008/ $p d f / 0158397967.2008 . p d f$.

Wolman, M.G., 1954, A method of sampling coarse river-bed material: Transactions of the American Geophysical Union, v. 35 , no. 6 , p. $951-956$. 



\section{Glossary}

\section{A}

Aggradation An increase in elevation of the channel bed, banks, or overbank areas of an alluvial river due to deposition of sediment.

Alluvium Sedimentary material that was deposited by flowing water. Examples of alluvial deposits include deltas, point bars, and sand in the flood-plain areas of rivers or streams.

\section{B}

Bedload Particles of sand, gravel, or soil from the channel bed that are transported by the natural flow of a stream or river on or immediately above the channel bed.

Boundary shear stress The force, in pounds per square foot, that flowing water applies to the channel bed and banks of a stream.

\section{C}

Colluvium Loose deposits of collapsed rock debris that accumulate at the base of a cliff or sloping valley.

Continuous-record streamgage Location where a water-stage recorder is used to collect continuous time-series stage data that are related to systematic discharge measurements at the station. Continuous-record streamgages are often operated for the purpose of longterm monitoring or as part of hydrologic investigations.

Crest-stage gage A device that will register the peak stage of the stream occurring between inspections of the gage. Crest-stage gages are typically used as a supplement to a water-stage recorder since the peak stage of a storm can occur in between recorded stage values. Crest-stage gages can be used to obtain high-water marks at a given location during a flood, or to determine water-surface slopes at different stream stages if placed in multiple locations along a reach of stream. A stage-discharge relation for the location of a crest-stage gage can be developed using discharge data obtained by indirect measurements of peak flow, or direct measurement of a range of discharges by use of a current meter or acoustic Doppler current profiler.

\section{D}

Degradation A decrease in elevation of the channel bed, banks, or overbank areas of an alluvial river due to erosion of sediment.

Dynamic equilibrium A steady-state condition where the net effect of flowing water is neither erosion of the channel bed nor deposition of sediment. Dynamic equilibrium generally occurs when there is balance between sediment input and sediment transport in a stream or river.

\section{E}

Event-mean discharge The mean discharge of a storm event, computed by dividing the total volume of direct runoff by the length of time in which that runoff occurs.

\section{F}

Fall Line The line marking the point on each stream where the flow descends from the eastern section of the Piedmont Physiographic Province to the western section of the Coastal Plain Physiographic Province in Maryland. The Fall Line is characterized by an abrupt decrease in channel slope in transition between the Piedmont and the Coastal Plain Physiographic Provinces.

Flashy A stream or watershed that tends to produce narrow, steeply peaked storm hydrographs that rise and fall very quickly.

Flood frequency Flood-frequency analysis is a method of estimating the chance that a peak discharge of a given magnitude will occur in any given year. The larger the magnitude of the discharge, the smaller the chance is that this discharge will occur in a given year. The analysis is based on recorded discharge data, specifically on the annual-peak series that are derived from streamgage data. This dataset consists of the largest instantaneous discharge, or peak flow, that occurs in each water year during which data collection occurred. The 
larger the dataset, the greater the confidence that can be assigned to the estimates derived from it.

\section{G}

Geomorphic Of, or pertaining to, the scientific study of landforms and the processes that shape them.

\section{H}

Hydraulic radius The cross-sectional area of a channel divided by the wetted perimeter.

\section{L}

Lateral erosion Erosion in which the removal of bank material extends laterally from the toe of the bank.

$\mathbf{P}$

Percent finer A cumulative percentage, associated with a particular particle size or diameter, that represents how much of the material that composes the channel bed or banks is smaller, or finer, than that particle diameter.

Piezometer An open-ended vertical pipe that is used for measurement of pressure and changes in pressure at a selected depth within an aquifer.

Porosity The ratio of the volume of voids to the total volume of a soil sample. Porosity is typically expressed as a percentage between 0 and 100 percent.

Probability A number expressing the statistical chance or likelihood that a storm event of a given magnitude will occur.

\section{R}

Rainfall-runoff relations The relation between the quantity of rain that falls during a precipitation event and the resulting amount of runoff that is conveyed by a stream channel. Rainfall-runoff relations are investigated as a means to quantify the hydrologic response of a watershed.

Relief The variation between the highest and lowest elevations at any location in a watershed, using a common elevation datum.
Riparian Relating to, living, or located on the bank of a natural watercourse, such as a river, stream, lake, or tidewater.

Riprap A layer or facing of rock that is placed to protect a bridge, embankment, or channel bank from erosion.

Run A longitudinal section of stream channel that has a moderate current, moderate depth, and a relatively smooth water surface.

\section{S}

Sinuosity The ratio of stream length to valley length. The minimum value for sinuosity is 1.0 for a straight channel, and increases depending on the amount of meandering in the reach of interest.

Stability The ability of a stream or river to transport its flow and sediment while maintaining its dimension, pattern, and profile with no net change in aggradation or degradation.

Suspended sediment Sediment in flowing water that is maintained in suspension by the upward components of turbulent currents in a stream or river.

\section{T}

Thalweg The lowest elevation across a cross section in a stream channel.

Time of concentration The length of time between the start of precipitation and the start of the corresponding increase in stream discharge at a point.

\section{W}

Water year The 12-month period beginning October 1 and ending September 30. The water year is designated by the calendar year in which it ends. For example, the year beginning October 1, 2005 and ending September 30,2006 is called "water year 2006."

Wetted perimeter The length along the cross-sectional boundary of a channel that is contacted by water at a given elevation. In an open channel, such as a stream or river, the cross-sectional boundary is the channel bed and banks. 
Appendix 1 
Appendix 1. Changes in cross-section geometry at permanent cross section Aa, Minebank Run study reach, 2005 through 2008.

[NGVD 29, National Geodetic Vertical Datum of 1929; ft, feet; ft², square feet; Apr., April; Dec., December; \%, percent]

\begin{tabular}{|c|c|c|c|c|c|c|c|c|c|c|}
\hline \multirow{2}{*}{$\begin{array}{l}\text { Elevation } \\
\text { (ft above } \\
\text { NGVD 29) }\end{array}$} & \multicolumn{5}{|c|}{$\begin{array}{c}\text { Cross-sectional area } \\
\left(\mathrm{ft}^{2}\right)\end{array}$} & \multicolumn{5}{|c|}{$\begin{array}{l}\text { Wetted perimeter } \\
\text { (ft) }\end{array}$} \\
\hline & $\begin{array}{l}\text { Apr. } \\
2005\end{array}$ & $\begin{array}{l}\text { Dec. } \\
2005\end{array}$ & 2006 & 2007 & 2008 & $\begin{array}{l}\text { Apr. } \\
2005\end{array}$ & $\begin{array}{l}\text { Dec. } \\
2005\end{array}$ & 2006 & 2007 & 2008 \\
\hline 212.00 & 28.1 & $\begin{array}{c}21.9 \\
(-22.1 \%)\end{array}$ & $\begin{array}{c}27.9 \\
(-0.7 \%)\end{array}$ & $\begin{array}{c}27.4 \\
(-2.5 \%)\end{array}$ & $\begin{array}{c}28.8 \\
(+2.5 \%)\end{array}$ & 31.0 & 28.8 & 32.0 & 33.3 & 32.8 \\
\hline 212.50 & 44.6 & $\begin{array}{c}37.9 \\
(-15.0 \%)\end{array}$ & $\begin{array}{c}44.5 \\
(-0.2 \%)\end{array}$ & $\begin{array}{c}44.5 \\
(-0.2 \%)\end{array}$ & $\begin{array}{c}45.8 \\
(+2.7 \%)\end{array}$ & 36.8 & 36.1 & 37.4 & 37.1 & 37.2 \\
\hline 213.00 & 63.8 & $\begin{array}{c}57.1 \\
(-10.5 \%)\end{array}$ & $\begin{array}{c}63.7 \\
(-0.2 \%)\end{array}$ & $\begin{array}{c}63.7 \\
(-0.2 \%)\end{array}$ & $\begin{array}{r}64.9 \\
(+1.7 \%)\end{array}$ & 41.2 & 41.5 & 42.2 & 41.6 & 42.1 \\
\hline 213.50 & 85.5 & $\begin{array}{c}78.7 \\
(-8.0 \%)\end{array}$ & $\begin{array}{c}85.2 \\
(-0.4 \%)\end{array}$ & $\begin{array}{c}85.1 \\
(-0.5 \%)\end{array}$ & $\begin{array}{c}86.1 \\
(+0.7 \%)\end{array}$ & 45.9 & 45.7 & 46.6 & 46.0 & 45.6 \\
\hline 214.00 & 108.9 & $\begin{array}{c}101.9 \\
(-6.4 \%)\end{array}$ & $\begin{array}{c}108.5 \\
(-0.4 \%)\end{array}$ & $\begin{array}{c}108.7 \\
(-0.2 \%)\end{array}$ & $\begin{array}{c}108.8 \\
(-0.1 \%)\end{array}$ & 50.0 & 49.0 & 50.4 & 50.7 & 48.7 \\
\hline 215.50 & 243.2 & $\begin{array}{c}234.2 \\
(-3.7 \%)\end{array}$ & $\begin{array}{c}243.1 \\
(0.0 \%)\end{array}$ & $\begin{array}{c}241.1 \\
(-0.9 \%)\end{array}$ & $\begin{array}{c}241.4 \\
(-0.7 \%)\end{array}$ & 92.9 & 92.7 & 93.9 & 93.7 & 94.8 \\
\hline 216.00 & 289.7 & $\begin{array}{c}281.3 \\
(-2.9 \%)\end{array}$ & $\begin{array}{c}290.2 \\
(+0.2 \%)\end{array}$ & $\begin{array}{c}288.5 \\
(-0.4 \%)\end{array}$ & $\begin{array}{c}289.5 \\
(-0.1 \%)\end{array}$ & 96.7 & 102.2 & 99.3 & 99.1 & 102.5 \\
\hline
\end{tabular}

\begin{tabular}{|c|c|c|c|c|c|c|c|c|c|c|c|c|c|c|c|}
\hline \multirow{2}{*}{$\begin{array}{l}\text { Elevation } \\
\text { (ft above } \\
\text { NGVD 29) }\end{array}$} & \multicolumn{5}{|c|}{$\begin{array}{l}\text { Hydraulic radius } \\
\text { (ft) }\end{array}$} & \multicolumn{5}{|c|}{$\begin{array}{c}\text { Channel width } \\
\text { (ft) }\end{array}$} & \multicolumn{5}{|c|}{$\begin{array}{l}\text { Mean channel depth } \\
\text { (ft) }\end{array}$} \\
\hline & $\begin{array}{l}\text { Apr. } \\
2005\end{array}$ & $\begin{array}{l}\text { Dec. } \\
2005\end{array}$ & 2006 & 2007 & 2008 & $\begin{array}{l}\text { Apr. } \\
2005\end{array}$ & $\begin{array}{l}\text { Dec. } \\
2005\end{array}$ & 2006 & 2007 & 2008 & $\begin{array}{l}\text { Apr. } \\
2005\end{array}$ & $\begin{array}{l}\text { Dec. } \\
2005\end{array}$ & 2006 & 2007 & 2008 \\
\hline 212.00 & 0.91 & 0.76 & 0.87 & 0.82 & 0.88 & 30.6 & 28.4 & 30.6 & 32.6 & 31.6 & 0.92 & 0.77 & 0.91 & 0.84 & 0.91 \\
\hline 212.50 & 1.21 & 1.05 & 1.19 & 1.20 & 1.23 & 36.2 & 35.5 & 36.0 & 36.2 & 35.8 & 1.23 & 1.07 & 1.24 & 1.23 & 1.28 \\
\hline 213.00 & 1.55 & 1.38 & 1.51 & 1.53 & 1.54 & 40.5 & 40.9 & 40.6 & 40.7 & 40.6 & 1.58 & 1.40 & 1.57 & 1.57 & 1.60 \\
\hline 214.00 & 2.18 & 2.08 & 2.15 & 2.14 & 2.23 & 48.9 & 48.0 & 48.5 & 49.5 & 46.9 & 2.23 & 2.12 & 2.24 & 2.20 & 2.32 \\
\hline 214.50 & 1.84 & 1.72 & 1.81 & 1.81 & 1.81 & 83.5 & 83.8 & 83.9 & 83.6 & 83.0 & 1.86 & 1.75 & 1.85 & 1.84 & 1.86 \\
\hline 215.00 & 2.23 & 2.13 & 2.21 & 2.21 & 2.21 & 87.5 & 87.7 & 87.6 & 87.5 & 86.9 & 2.27 & 2.16 & 2.26 & 2.24 & 2.26 \\
\hline 215.50 & 2.62 & 2.53 & 2.59 & 2.57 & 2.55 & 91.3 & 91.2 & 91.6 & 92.1 & 92.5 & 2.66 & 2.57 & 2.65 & 2.62 & 2.61 \\
\hline
\end{tabular}

Note: Percentages shown in parentheses under cross-sectional areas represent the percent change in area from the April 2005 survey. 
Appendix 1. Changes in cross-section geometry at permanent cross section Bb, Minebank Run study reach, 2005 through 2008. -Continued

[NGVD 29, National Geodetic Vertical Datum of 1929; ft, feet; $\mathrm{ft}^{2}$, square feet; Apr., April; Dec., December; \%, percent]

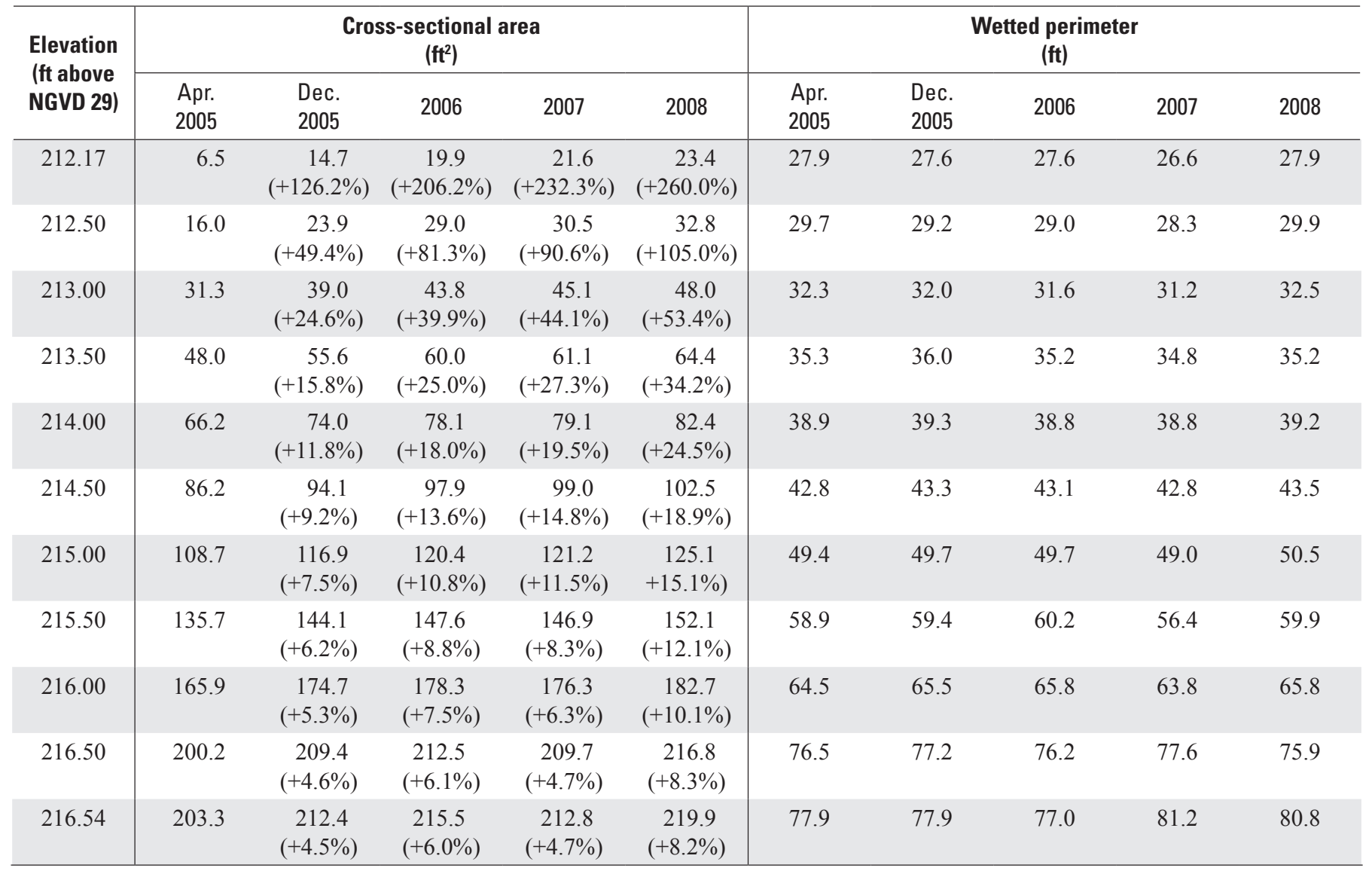

\begin{tabular}{|c|c|c|c|c|c|c|c|c|c|c|c|c|c|c|c|}
\hline \multirow{2}{*}{$\begin{array}{l}\text { Elevation } \\
\text { (ft above } \\
\text { NGVD 29) }\end{array}$} & \multicolumn{5}{|c|}{$\begin{array}{c}\text { Hydraulic radius } \\
\text { (ft) }\end{array}$} & \multicolumn{5}{|c|}{$\begin{array}{c}\text { Channel width } \\
\text { (ft) }\end{array}$} & \multicolumn{5}{|c|}{$\begin{array}{c}\text { Mean channel depth } \\
\text { (ft) }\end{array}$} \\
\hline & $\begin{array}{l}\text { Apr. } \\
2005\end{array}$ & $\begin{array}{l}\text { Dec. } \\
2005\end{array}$ & 2006 & 2007 & 2008 & $\begin{array}{l}\text { Apr. } \\
2005\end{array}$ & $\begin{array}{l}\text { Dec. } \\
2005\end{array}$ & 2006 & 2007 & 2008 & $\begin{array}{l}\text { Apr. } \\
2005\end{array}$ & $\begin{array}{l}\text { Dec. } \\
2005\end{array}$ & 2006 & 2007 & 2008 \\
\hline 212.17 & 0.23 & 0.53 & 0.72 & 0.81 & 0.84 & 27.8 & 27.4 & 27.2 & 26.2 & 27.4 & 0.23 & 0.54 & 0.73 & 0.82 & 0.85 \\
\hline 212.50 & 0.54 & 0.82 & 1.00 & 1.08 & 1.10 & 29.5 & 28.9 & 28.5 & 27.8 & 29.3 & 0.54 & 0.83 & 1.02 & 1.10 & 1.12 \\
\hline 213.00 & 0.97 & 1.22 & 1.39 & 1.45 & 1.48 & 31.9 & 31.4 & 30.8 & 30.5 & 31.7 & 0.98 & 1.24 & 1.42 & 1.48 & 1.51 \\
\hline 214.00 & 1.70 & 1.88 & 2.01 & 2.04 & 2.10 & 38.2 & 38.5 & 37.8 & 37.8 & 37.9 & 1.73 & 1.92 & 2.07 & 2.09 & 2.17 \\
\hline 214.50 & 2.01 & 2.17 & 2.27 & 2.31 & 2.36 & 42.0 & 42.3 & 41.9 & 41.7 & 42.1 & 2.05 & 2.22 & 2.34 & 2.37 & 2.43 \\
\hline 215.00 & 2.20 & 2.35 & 2.42 & 2.47 & 2.48 & 48.5 & 48.6 & 48.4 & 47.8 & 49.0 & 2.24 & 2.41 & 2.49 & 2.54 & 2.55 \\
\hline 215.50 & 2.30 & 2.43 & 2.45 & 2.60 & 2.54 & 57.9 & 58.2 & 58.8 & 55.1 & 58.3 & 2.34 & 2.48 & 2.51 & 2.67 & 2.61 \\
\hline
\end{tabular}

Note: Percentages shown in parentheses under cross-sectional areas represent the percent change in area from the April 2005 survey. 
Appendix 1. Changes in cross-section geometry at permanent cross section Cc, Minebank Run study reach, 2005 through 2008. -Continued

[NGVD 29, National Geodetic Vertical Datum of 1929; ft, feet; ft², square feet; Apr., April; Dec., December; \%, percent]

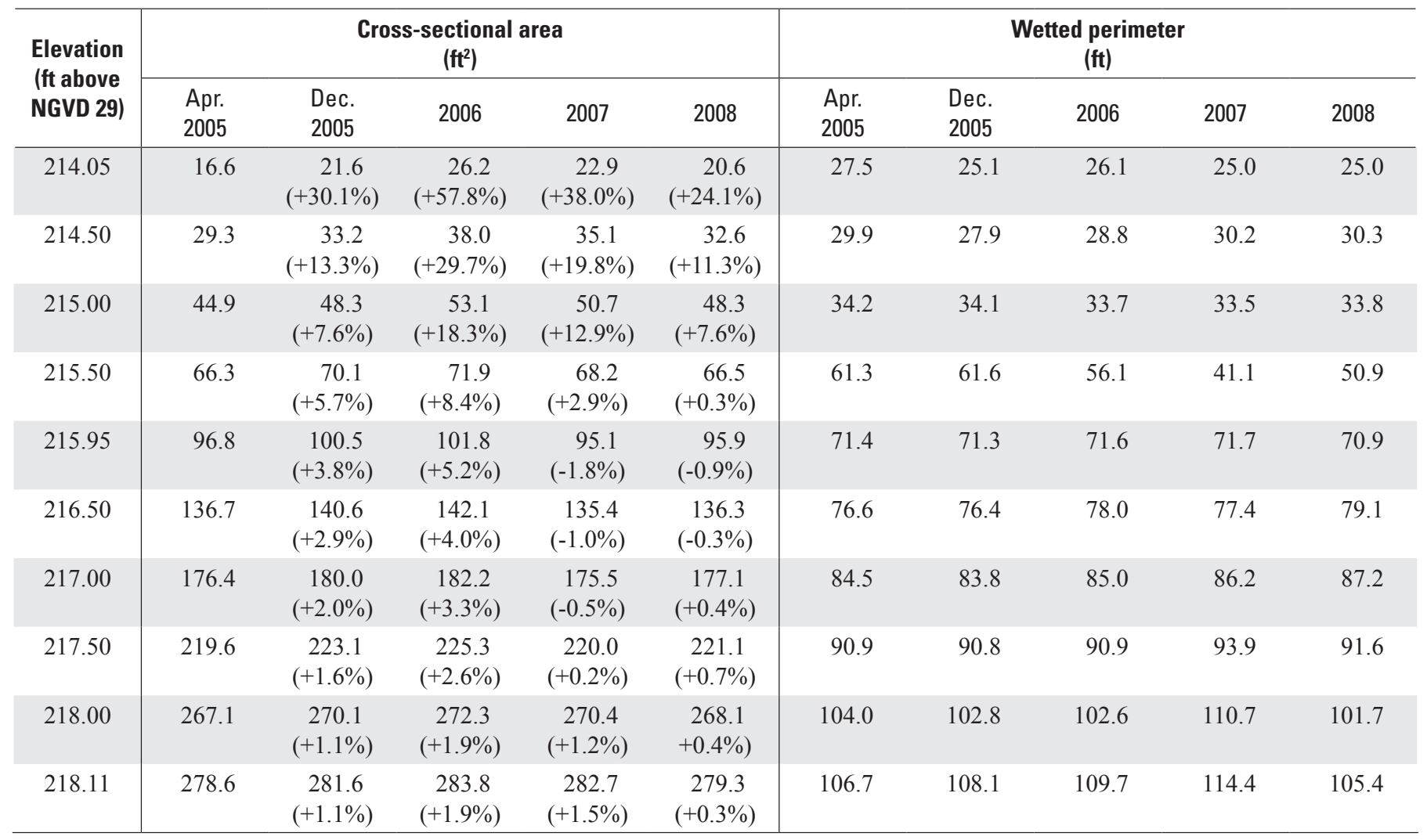

\begin{tabular}{|c|c|c|c|c|c|c|c|c|c|c|c|c|c|c|c|}
\hline \multirow{2}{*}{$\begin{array}{l}\text { Elevation } \\
\text { (ft above } \\
\text { NGVD 29) }\end{array}$} & \multicolumn{5}{|c|}{$\begin{array}{l}\text { Hydraulic radius } \\
\text { (ft) }\end{array}$} & \multicolumn{5}{|c|}{$\begin{array}{c}\text { Channel width } \\
\text { (ft) }\end{array}$} & \multicolumn{5}{|c|}{$\begin{array}{l}\text { Mean channel depth } \\
\text { (ft) }\end{array}$} \\
\hline & $\begin{array}{l}\text { Apr. } \\
2005\end{array}$ & $\begin{array}{l}\text { Dec. } \\
2005\end{array}$ & 2006 & 2007 & 2008 & $\begin{array}{l}\text { Apr. } \\
2005\end{array}$ & $\begin{array}{l}\text { Dec. } \\
2005\end{array}$ & 2006 & 2007 & 2008 & $\begin{array}{l}\text { Apr. } \\
2005\end{array}$ & $\begin{array}{l}\text { Dec. } \\
2005\end{array}$ & 2006 & 2007 & 2008 \\
\hline 214.05 & 0.60 & 0.86 & 1.00 & 0.92 & 0.82 & 27.2 & 24.8 & 25.4 & 24.5 & 24.5 & 0.61 & 0.87 & 1.03 & 0.93 & 0.84 \\
\hline 214.50 & 0.98 & 1.19 & 1.32 & 1.16 & 1.08 & 29.3 & 27.4 & 27.8 & 29.6 & 29.7 & 1.00 & 1.21 & 1.37 & 1.19 & 1.10 \\
\hline 215.00 & 1.31 & 1.42 & 1.58 & 1.49 & 1.43 & 33.5 & 33.5 & 32.6 & 32.7 & 33.1 & 1.34 & 1.44 & 1.63 & 1.55 & 1.46 \\
\hline 215.95 & 1.36 & 1.41 & 1.42 & 1.33 & 1.35 & 70.4 & 70.4 & 70.3 & 70.7 & 69.9 & 1.38 & 1.43 & 1.45 & 1.35 & 1.37 \\
\hline 216.50 & 1.78 & 1.84 & 1.82 & 1.75 & 1.72 & 75.5 & 75.4 & 76.5 & 76.2 & 78.0 & 1.81 & 1.86 & 1.86 & 1.78 & 1.75 \\
\hline 217.00 & 2.09 & 2.15 & 2.14 & 2.04 & 2.03 & 83.3 & 82.7 & 83.4 & 85.0 & 85.9 & 2.12 & 2.18 & 2.18 & 2.06 & 2.06 \\
\hline 217.50 & 2.42 & 2.46 & 2.48 & 2.34 & 2.41 & 89.6 & 89.6 & 89.2 & 92.6 & 90.3 & 2.45 & 2.49 & 2.53 & 2.38 & 2.45 \\
\hline
\end{tabular}

Note: Percentages shown in parentheses under cross-sectional areas represent the percent change in area from the April 2005 survey. 
Appendix 1. Changes in cross-section geometry at permanent cross section Dd, Minebank Run study reach, 2005 through 2008. -Continued

[NGVD 29, National Geodetic Vertical Datum of 1929; ft, feet; $\mathrm{ft}^{2}$, square feet; Apr., April; Dec., December; \%, percent]

\begin{tabular}{|c|c|c|c|c|c|c|c|c|c|c|}
\hline \multirow{2}{*}{$\begin{array}{l}\text { Elevation } \\
\text { (ft above } \\
\text { NGVD 29) }\end{array}$} & \multicolumn{5}{|c|}{$\begin{array}{c}\text { Cross-sectional area } \\
\left(\mathrm{ft}^{2}\right)\end{array}$} & \multicolumn{5}{|c|}{$\begin{array}{c}\text { Wetted perimeter } \\
\text { (ft) }\end{array}$} \\
\hline & $\begin{array}{l}\text { Apr. } \\
2005\end{array}$ & $\begin{array}{l}\text { Dec. } \\
2005\end{array}$ & 2006 & 2007 & 2008 & $\begin{array}{l}\text { Apr. } \\
2005\end{array}$ & $\begin{array}{l}\text { Dec. } \\
2005\end{array}$ & 2006 & 2007 & 2008 \\
\hline 215.00 & 0.4 & $\begin{array}{c}5.4 \\
(+1,250.0 \%)\end{array}$ & $\begin{array}{c}2.5 \\
(+525.0 \%)\end{array}$ & $\begin{array}{c}1.8 \\
(+350.0 \%)\end{array}$ & $\begin{array}{c}2.9 \\
(+625.0 \%)\end{array}$ & 5.4 & 19.0 & 12.6 & 8.9 & 12.7 \\
\hline 215.50 & 9.0 & $\begin{array}{c}16.1 \\
(+78.9 \%)\end{array}$ & $\begin{array}{c}12.4 \\
(+37.8 \%)\end{array}$ & $\begin{array}{c}8.8 \\
(-2.2 \%)\end{array}$ & $\begin{array}{c}12.2 \\
(+35.6 \%)\end{array}$ & 24.2 & 23.9 & 22.9 & 19.5 & 23.0 \\
\hline 216.00 & 22.5 & $\begin{array}{c}28.6 \\
(+27.1 \%)\end{array}$ & $\begin{array}{r}24.2 \\
(+7.6 \%)\end{array}$ & $\begin{array}{c}19.7 \\
(-12.4 \%)\end{array}$ & $\begin{array}{c}25.3 \\
(+12.4 \%)\end{array}$ & 29.5 & 27.5 & 26.7 & 24.8 & 28.9 \\
\hline 216.50 & 37.8 & $\begin{array}{c}42.8 \\
(+13.2 \%)\end{array}$ & $\begin{array}{c}38.3 \\
(+1.3 \%)\end{array}$ & $\begin{array}{c}33.4 \\
(-11.6 \%)\end{array}$ & $\begin{array}{c}40.3 \\
(+6.6 \%)\end{array}$ & 32.4 & 31.7 & 31.2 & 30.6 & 32.5 \\
\hline 217.00 & 54.5 & $\begin{array}{c}59.3 \\
(+8.8 \%)\end{array}$ & $\begin{array}{c}54.4 \\
(-0.2 \%)\end{array}$ & $\begin{array}{c}49.7 \\
(-8.8 \%)\end{array}$ & $\begin{array}{c}56.8 \\
(+4.2 \%)\end{array}$ & 35.3 & 36.0 & 35.6 & 35.4 & 36.0 \\
\hline 218.38 & 109.3 & $\begin{array}{l}115.1 \\
(+5.3 \%)\end{array}$ & $\begin{array}{c}110.4 \\
(+1.0 \%)\end{array}$ & $\begin{array}{c}106.4 \\
(-2.7 \%)\end{array}$ & $\begin{array}{c}113.4 \\
(+3.8 \%)\end{array}$ & 47.5 & 49.0 & 50.2 & 48.2 & 49.8 \\
\hline 218.50 & 115.0 & $\begin{array}{l}120.9 \\
(+5.1 \%)\end{array}$ & $\begin{array}{c}116.4 \\
(+1.2 \%)\end{array}$ & $\begin{array}{c}112.2 \\
(-2.4 \%)\end{array}$ & $\begin{array}{c}166.4 \\
(+44.7 \%)\end{array}$ & 48.9 & 51.4 & 54.1 & 49.4 & 107.7 \\
\hline 218.75 & 187.7 & $\begin{array}{l}193.8 \\
(+3.2 \%)\end{array}$ & $\begin{array}{c}190.3 \\
(+1.4 \%)\end{array}$ & $\begin{array}{c}188.9 \\
(+0.6 \%)\end{array}$ & $\begin{array}{c}193.2 \\
(+2.9 \%)\end{array}$ & 113.7 & 113.2 & 112.0 & 114.9 & 112.0 \\
\hline
\end{tabular}

\begin{tabular}{|c|c|c|c|c|c|c|c|c|c|c|c|c|c|c|c|}
\hline \multirow{2}{*}{$\begin{array}{l}\text { Elevation } \\
\text { (ft above } \\
\text { NGVD 29) }\end{array}$} & \multicolumn{5}{|c|}{$\begin{array}{l}\text { Hydraulic radius } \\
\text { (ft) }\end{array}$} & \multicolumn{5}{|c|}{$\begin{array}{c}\text { Channel width } \\
\text { (ft) }\end{array}$} & \multicolumn{5}{|c|}{$\begin{array}{l}\text { Mean channel depth } \\
\text { (ft) }\end{array}$} \\
\hline & $\begin{array}{l}\text { Apr. } \\
2005\end{array}$ & $\begin{array}{l}\text { Dec. } \\
2005\end{array}$ & 2006 & 2007 & 2008 & $\begin{array}{l}\text { Apr. } \\
2005\end{array}$ & $\begin{array}{l}\text { Dec. } \\
2005\end{array}$ & 2006 & 2007 & 2008 & $\begin{array}{l}\text { Apr. } \\
2005\end{array}$ & $\begin{array}{l}\text { Dec. } \\
2005\end{array}$ & 2006 & 2007 & 2008 \\
\hline 215.00 & 0.074 & 0.28 & 0.20 & 0.20 & 0.23 & 5.3 & 18.5 & 12.5 & 8.8 & 12.5 & 0.075 & 0.29 & 0.20 & 0.20 & 0.23 \\
\hline 215.50 & 0.37 & 0.67 & 0.54 & 0.45 & 0.53 & 24.1 & 23.2 & 22.3 & 19.3 & 22.4 & 0.37 & 0.69 & 0.56 & 0.46 & 0.54 \\
\hline 216.00 & 0.76 & 1.04 & 0.91 & 0.79 & 0.88 & 29.3 & 26.7 & 25.9 & 24.5 & 28.1 & 0.77 & 1.07 & 0.93 & 0.80 & 0.90 \\
\hline 217.00 & 1.54 & 1.65 & 1.53 & 1.40 & 1.58 & 34.7 & 34.9 & 34.5 & 34.8 & 34.8 & 1.57 & 1.70 & 1.58 & 1.43 & 1.63 \\
\hline 217.50 & 1.86 & 1.95 & 1.83 & 1.70 & 1.85 & 38.2 & 38.6 & 38.6 & 39.4 & 39.5 & 1.90 & 2.01 & 1.88 & 1.73 & 1.91 \\
\hline 218.00 & 2.19 & 2.23 & 2.09 & 1.99 & 2.15 & 41.6 & 42.6 & 43.0 & 43.9 & 43.3 & 2.23 & 2.30 & 2.16 & 2.03 & 2.22 \\
\hline 218.38 & 2.30 & 2.35 & 2.20 & 2.21 & 2.28 & 46.5 & 47.6 & 48.8 & 47.4 & 48.3 & 2.35 & 2.42 & 2.26 & 2.24 & 2.35 \\
\hline
\end{tabular}

Note: Percentages shown in parentheses under cross-sectional areas represent the percent change in area from the April 2005 survey. 
Appendix 1. Changes in cross-section geometry at permanent cross section Ee, Minebank Run study reach, 2005 through 2008. -Continued

[NGVD 29, National Geodetic Vertical Datum of 1929; ft, feet; $\mathrm{ft}^{2}$, square feet; Apr., April; Nov., November; \%, percent]

\begin{tabular}{|c|c|c|c|c|c|c|c|c|c|c|}
\hline \multirow{2}{*}{$\begin{array}{l}\text { Elevation } \\
\text { (ft above } \\
\text { NGVD 29) }\end{array}$} & \multicolumn{5}{|c|}{$\begin{array}{c}\text { Cross-sectional area } \\
\left(\mathrm{ft}^{2}\right)\end{array}$} & \multicolumn{5}{|c|}{$\begin{array}{c}\text { Wetted perimeter } \\
\text { (ft) }\end{array}$} \\
\hline & $\begin{array}{l}\text { Apr. } \\
2005\end{array}$ & $\begin{array}{l}\text { Nov. } \\
2005\end{array}$ & 2006 & 2007 & 2008 & $\begin{array}{l}\text { Apr. } \\
2005\end{array}$ & $\begin{array}{l}\text { Nov. } \\
2005\end{array}$ & 2006 & 2007 & 2008 \\
\hline 216.50 & 4.4 & $\begin{array}{c}9.2 \\
(+109.1 \%)\end{array}$ & $\begin{array}{c}8.0 \\
(+81.8 \%)\end{array}$ & $\begin{array}{c}8.1 \\
(+84.1 \%)\end{array}$ & $\begin{array}{c}7.9 \\
(+79.5 \%)\end{array}$ & 15.2 & 12.4 & 14.8 & 14.1 & 14.7 \\
\hline 217.00 & 14.7 & $\begin{array}{c}16.7 \\
(+13.6 \%)\end{array}$ & $\begin{array}{c}16.8 \\
(+14.3 \%)\end{array}$ & $\begin{array}{c}16.5 \\
(+12.2 \%)\end{array}$ & $\begin{array}{c}16.7 \\
(+13.6 \%)\end{array}$ & 25.3 & 18.2 & 21.5 & 21.7 & 23.7 \\
\hline 217.50 & 29.2 & $\begin{array}{c}26.6 \\
(-8.9 \%)\end{array}$ & $\begin{array}{c}29.0 \\
(-0.7 \%)\end{array}$ & $\begin{array}{c}28.6 \\
(-2.1 \%)\end{array}$ & $\begin{array}{c}29.3 \\
(+0.3 \%)\end{array}$ & 32.5 & 24.2 & 28.3 & 28.4 & 28.6 \\
\hline 218.00 & 46.7 & $\begin{array}{c}42.2 \\
(-9.6 \%)\end{array}$ & $\begin{array}{c}43.6 \\
(-6.6 \%)\end{array}$ & $\begin{array}{c}43.3 \\
(-7.3 \%)\end{array}$ & $\begin{array}{c}43.9 \\
(-6.0 \%)\end{array}$ & 38.0 & 37.3 & 33.2 & 33.2 & 32.6 \\
\hline 218.50 & 66.4 & $\begin{array}{c}61.8 \\
(-6.9 \%)\end{array}$ & $\begin{array}{c}61.1 \\
(-8.0 \%)\end{array}$ & $\begin{array}{c}60.7 \\
(-8.6 \%)\end{array}$ & $\begin{array}{c}61.0 \\
(-8.1 \%)\end{array}$ & 41.7 & 42.0 & 39.4 & 39.3 & 39.5 \\
\hline
\end{tabular}

\begin{tabular}{|c|c|c|c|c|c|c|c|c|c|c|c|c|c|c|c|}
\hline \multirow{2}{*}{$\begin{array}{l}\text { Elevation } \\
\text { (ft above } \\
\text { NGVD 29) }\end{array}$} & \multicolumn{5}{|c|}{$\begin{array}{l}\text { Hydraulic radius } \\
\text { (ft) }\end{array}$} & \multicolumn{5}{|c|}{$\begin{array}{l}\text { Channel width } \\
\text { (ft) }\end{array}$} & \multicolumn{5}{|c|}{$\begin{array}{l}\text { Mean channel depth } \\
\text { (ft) }\end{array}$} \\
\hline & $\begin{array}{l}\text { Apr. } \\
2005\end{array}$ & $\begin{array}{l}\text { Nov. } \\
2005\end{array}$ & 2006 & 2007 & 2008 & $\begin{array}{l}\text { Apr. } \\
2005\end{array}$ & $\begin{array}{l}\text { Nov. } \\
2005\end{array}$ & 2006 & 2007 & 2008 & $\begin{array}{l}\text { Apr. } \\
2005\end{array}$ & $\begin{array}{l}\text { Nov. } \\
2005\end{array}$ & 2006 & 2007 & 2008 \\
\hline 216.50 & 0.29 & 0.74 & 0.54 & 0.57 & 0.54 & 15.0 & 11.9 & 14.4 & 13.5 & 14.0 & 0.29 & 0.77 & 0.56 & 0.60 & 0.56 \\
\hline 217.00 & 0.58 & 0.92 & 0.78 & 0.76 & 0.70 & 24.9 & 17.5 & 20.8 & 20.6 & 22.7 & 0.59 & 0.95 & 0.81 & 0.80 & 0.74 \\
\hline 217.50 & 0.90 & 1.10 & 1.02 & 1.01 & 1.02 & 32.0 & 23.4 & 27.3 & 27.1 & 27.3 & 0.91 & 1.14 & 1.06 & 1.06 & 1.07 \\
\hline 218.50 & 1.59 & 1.47 & 1.55 & 1.54 & 1.54 & 40.9 & 40.9 & 38.1 & 37.8 & 37.9 & 1.62 & 1.51 & 1.60 & 1.61 & 1.61 \\
\hline 219.00 & 1.98 & 1.86 & 1.86 & 1.83 & 1.83 & 43.0 & 43.1 & 42.3 & 42.6 & 42.8 & 2.03 & 1.92 & 1.93 & 1.90 & 1.90 \\
\hline 219.38 & 1.91 & 1.78 & 2.10 & 2.07 & 2.08 & 53.7 & 54.9 & 45.1 & 45.5 & 45.4 & 1.95 & 1.83 & 2.18 & 2.15 & 2.16 \\
\hline
\end{tabular}

Note: Percentages shown in parentheses under cross-sectional areas represent the percent change in area from the April 2005 survey. 
Appendix 1. Changes in cross-section geometry at permanent cross section Ff, Minebank Run study reach, 2005 through 2008. -Continued

[NGVD 29, National Geodetic Vertical Datum of 1929; ft, feet; ft², square feet; Apr., April; Nov., November; \%, percent]

\begin{tabular}{|c|c|c|c|c|c|c|c|c|c|c|}
\hline \multirow{2}{*}{$\begin{array}{l}\text { Elevation } \\
\text { (ft above } \\
\text { NGVD 29) }\end{array}$} & \multicolumn{5}{|c|}{$\begin{array}{c}\text { Cross-sectional area } \\
\left(\mathrm{ft}^{2}\right)\end{array}$} & \multicolumn{5}{|c|}{$\begin{array}{c}\text { Wetted perimeter } \\
\text { (ft) }\end{array}$} \\
\hline & $\begin{array}{l}\text { Apr. } \\
2005\end{array}$ & $\begin{array}{l}\text { Nov. } \\
2005\end{array}$ & 2006 & 2007 & 2008 & $\begin{array}{l}\text { Apr. } \\
2005\end{array}$ & $\begin{array}{l}\text { Nov. } \\
2005\end{array}$ & 2006 & 2007 & 2008 \\
\hline 219.00 & 26.9 & $\begin{array}{c}22.1 \\
(-17.8 \%)\end{array}$ & $\begin{array}{c}29.0 \\
(+7.8 \%)\end{array}$ & $\begin{array}{c}28.8 \\
(+7.1 \%)\end{array}$ & $\begin{array}{c}30.7 \\
(+14.1 \%)\end{array}$ & 26.1 & 21.9 & 21.4 & 26.7 & 27.3 \\
\hline 219.50 & 40.2 & $\begin{array}{c}34.0 \\
(-15.4 \%)\end{array}$ & $\begin{array}{c}40.2 \\
(0.0 \%)\end{array}$ & $\begin{array}{c}42.2 \\
(+5.0 \%)\end{array}$ & $\begin{array}{c}43.7 \\
(+8.7 \%)\end{array}$ & 32.9 & 26.6 & 27.2 & 31.2 & 31.2 \\
\hline 220.00 & 57.7 & $\begin{array}{c}51.4 \\
(-10.9 \%)\end{array}$ & $\begin{array}{c}56.0 \\
(-2.9 \%)\end{array}$ & $\begin{array}{c}58.3 \\
(+1.0 \%)\end{array}$ & $\begin{array}{c}60.1 \\
(+4.2 \%)\end{array}$ & 39.8 & 40.3 & 38.1 & 39.0 & 43.2 \\
\hline 220.50 & 77.1 & $\begin{array}{c}71.8 \\
(-6.9 \%)\end{array}$ & $\begin{array}{c}76.0 \\
(-1.4 \%)\end{array}$ & $\begin{array}{c}77.8 \\
(+0.9 \%)\end{array}$ & $\begin{array}{c}80.2 \\
(+4.0 \%)\end{array}$ & 42.9 & 43.6 & 44.2 & 44.2 & 45.4 \\
\hline 221.00 & 98.1 & $\begin{array}{c}93.5 \\
(-4.7 \%)\end{array}$ & $\begin{array}{c}97.7 \\
(-0.4 \%)\end{array}$ & $\begin{array}{c}98.8 \\
(+0.7 \%)\end{array}$ & $\begin{array}{c}101.6 \\
(+3.6 \%)\end{array}$ & 46.4 & 46.1 & 48.5 & 47.1 & 49.9 \\
\hline 222.34 & 350.5 & $\begin{array}{c}352.1 \\
(+0.5 \%)\end{array}$ & $\begin{array}{c}357.3 \\
(+1.9 \%)\end{array}$ & $\begin{array}{c}353.8 \\
(+0.9 \%)\end{array}$ & $\begin{array}{c}359.3 \\
(+2.5 \%)\end{array}$ & 149.1 & 152.2 & 150.6 & 147.1 & 155.8 \\
\hline
\end{tabular}

\begin{tabular}{|c|c|c|c|c|c|c|c|c|c|c|c|c|c|c|c|}
\hline \multirow{2}{*}{$\begin{array}{l}\text { Elevation } \\
\text { (ft above } \\
\text { NGVD 29) }\end{array}$} & \multicolumn{5}{|c|}{$\begin{array}{l}\text { Hydraulic radius } \\
\text { (ft) }\end{array}$} & \multicolumn{5}{|c|}{$\begin{array}{c}\text { Channel width } \\
\text { (ft) }\end{array}$} & \multicolumn{5}{|c|}{$\begin{array}{c}\text { Mean channel depth } \\
\text { (ft) }\end{array}$} \\
\hline & $\begin{array}{l}\text { Apr. } \\
2005\end{array}$ & $\begin{array}{l}\text { Nov. } \\
2005\end{array}$ & 2006 & 2007 & 2008 & $\begin{array}{l}\text { Apr. } \\
2005\end{array}$ & $\begin{array}{l}\text { Nov. } \\
2005\end{array}$ & 2006 & 2007 & 2008 & $\begin{array}{l}\text { Apr. } \\
2005\end{array}$ & $\begin{array}{l}\text { Nov. } \\
2005\end{array}$ & 2006 & 2007 & 2008 \\
\hline 219.00 & 1.03 & 1.01 & 1.36 & 1.08 & 1.12 & 24.7 & 21.3 & 20.0 & 25.1 & 24.6 & 1.09 & 1.04 & 1.45 & 1.15 & 1.25 \\
\hline 219.50 & 1.22 & 1.28 & 1.48 & 1.35 & 1.40 & 31.1 & 25.7 & 25.4 & 29.2 & 28.1 & 1.29 & 1.32 & 1.58 & 1.45 & 1.56 \\
\hline 220.00 & 1.45 & 1.28 & 1.47 & 1.49 & 1.39 & 37.4 & 39.2 & 36.1 & 36.1 & 39.3 & 1.54 & 1.31 & 1.55 & 1.61 & 1.53 \\
\hline 221.00 & 2.11 & 2.03 & 2.01 & 2.10 & 2.04 & 43.4 & 44.5 & 45.5 & 43.2 & 44.9 & 2.26 & 2.10 & 2.15 & 2.29 & 2.26 \\
\hline 221.50 & 2.33 & 2.30 & 2.34 & 2.25 & 2.33 & 48.6 & 48.8 & 48.6 & 50.3 & 48.5 & 2.49 & 2.39 & 2.49 & 2.43 & 2.57 \\
\hline 222.00 & 2.13 & 2.13 & 2.14 & 2.13 & 2.11 & 138.2 & 139.9 & 140.4 & 138.7 & 141.2 & 2.19 & 2.17 & 2.19 & 2.21 & 2.19 \\
\hline 222.34 & 2.35 & 2.31 & 2.37 & 2.41 & 2.31 & 145.1 & 149.7 & 146.8 & 142.1 & 150.0 & 2.42 & 2.35 & 2.43 & 2.49 & 2.40 \\
\hline
\end{tabular}

Note: Percentages shown in parentheses under cross-sectional areas represent the percent change in area from the April 2005 survey. 
Appendix 1. Changes in cross-section geometry at permanent cross section Gg, Minebank Run study reach, 2005 through 2008. -Continued

[NGVD 29, National Geodetic Vertical Datum of 1929; ft, feet; ft², square feet; Apr., April; Nov., November; \%, percent]

\begin{tabular}{|c|c|c|c|c|c|c|c|c|c|c|}
\hline \multirow{2}{*}{$\begin{array}{l}\text { Elevation } \\
\text { (ft above } \\
\text { NGVD 29) }\end{array}$} & \multicolumn{5}{|c|}{$\begin{array}{c}\text { Cross-sectional area } \\
\left(\mathrm{ft}^{2}\right)\end{array}$} & \multicolumn{5}{|c|}{$\begin{array}{c}\text { Wetted perimeter } \\
\text { (ft) }\end{array}$} \\
\hline & $\begin{array}{l}\text { Apr. } \\
2005\end{array}$ & $\begin{array}{l}\text { Nov. } \\
2005\end{array}$ & 2006 & 2007 & 2008 & $\begin{array}{l}\text { Apr. } \\
2005\end{array}$ & $\begin{array}{l}\text { Nov. } \\
2005\end{array}$ & 2006 & 2007 & 2008 \\
\hline 220.80 & 52.7 & $\begin{array}{c}61.0 \\
(+15.7 \%)\end{array}$ & $\begin{array}{c}41.0 \\
(-22.2 \%)\end{array}$ & $\begin{array}{c}42.0 \\
(-20.3 \%)\end{array}$ & $\begin{array}{c}41.8 \\
(-20.7 \%)\end{array}$ & 36.0 & 37.1 & 34.7 & 34.6 & 34.2 \\
\hline 221.00 & 59.9 & $\begin{array}{c}68.4 \\
(+14.2 \%)\end{array}$ & $\begin{array}{c}47.8 \\
(-20.2 \%)\end{array}$ & $\begin{array}{c}48.9 \\
(-18.4 \%)\end{array}$ & $\begin{array}{c}48.6 \\
(-18.9 \%)\end{array}$ & 38.6 & 39.1 & 35.7 & 36.1 & 35.7 \\
\hline 221.50 & 79.3 & $\begin{array}{c}88.2 \\
(+11.2 \%)\end{array}$ & $\begin{array}{c}66.6 \\
(-16.0 \%)\end{array}$ & $\begin{array}{c}68.1 \\
(-14.1 \%)\end{array}$ & $\begin{array}{c}67.7 \\
(-14.6 \%)\end{array}$ & 41.3 & 42.8 & 41.4 & 41.4 & 41.6 \\
\hline 222.00 & 99.3 & $\begin{array}{c}108.8 \\
(+9.6 \%)\end{array}$ & $\begin{array}{c}87.1 \\
(-12.3 \%)\end{array}$ & $\begin{array}{c}88.9 \\
(-10.5 \%)\end{array}$ & $\begin{array}{c}88.7 \\
(-10.7 \%)\end{array}$ & 42.9 & 44.5 & 44.1 & 44.2 & 44.8 \\
\hline 222.50 & 120.3 & $\begin{array}{c}130.3 \\
(+8.3 \%)\end{array}$ & $\begin{array}{c}109.1 \\
(-9.3 \%)\end{array}$ & $\begin{array}{c}110.9 \\
(-7.8 \%)\end{array}$ & $\begin{array}{c}111.1 \\
(-7.6 \%)\end{array}$ & 45.7 & 47.2 & 47.5 & 46.9 & 47.6 \\
\hline
\end{tabular}

\begin{tabular}{|c|c|c|c|c|c|c|c|c|c|c|c|c|c|c|c|}
\hline \multirow{2}{*}{$\begin{array}{l}\text { Elevation } \\
\text { (ft above } \\
\text { NGVD 29) }\end{array}$} & \multicolumn{5}{|c|}{$\begin{array}{l}\text { Hydraulic radius } \\
\text { (ft) }\end{array}$} & \multicolumn{5}{|c|}{$\begin{array}{l}\text { Channel width } \\
\text { (ft) }\end{array}$} & \multicolumn{5}{|c|}{$\begin{array}{l}\text { Mean channel depth } \\
\text { (ft) }\end{array}$} \\
\hline & $\begin{array}{l}\text { Apr. } \\
2005\end{array}$ & $\begin{array}{l}\text { Nov. } \\
2005\end{array}$ & 2006 & 2007 & 2008 & $\begin{array}{l}\text { Apr. } \\
2005\end{array}$ & $\begin{array}{l}\text { Nov. } \\
2005\end{array}$ & 2006 & 2007 & 2008 & $\begin{array}{l}\text { Apr. } \\
2005\end{array}$ & $\begin{array}{l}\text { Nov. } \\
2005\end{array}$ & 2006 & 2007 & 2008 \\
\hline 220.80 & 1.46 & 1.64 & 1.18 & 1.21 & 1.22 & 34.7 & 35.6 & 33.6 & 33.8 & 33.4 & 1.52 & 1.71 & 1.22 & 1.24 & 1.25 \\
\hline 221.00 & 1.55 & 1.75 & 1.34 & 1.35 & 1.36 & 37.1 & 37.4 & 34.5 & 35.3 & 34.7 & 1.61 & 1.83 & 1.39 & 1.39 & 1.40 \\
\hline 221.50 & 1.92 & 2.06 & 1.61 & 1.64 & 1.63 & 39.5 & 40.7 & 39.9 & 40.2 & 40.4 & 2.01 & 2.17 & 1.67 & 1.69 & 1.68 \\
\hline 222.50 & 2.63 & 2.76 & 2.30 & 2.36 & 2.33 & 43.3 & 44.1 & 45.5 & 45.1 & 46.0 & 2.78 & 2.95 & 2.40 & 2.46 & 2.42 \\
\hline 223.00 & 2.90 & 3.03 & 2.60 & 2.70 & 2.65 & 46.6 & 47.1 & 48.8 & 47.5 & 49.1 & 3.06 & 3.25 & 2.72 & 2.82 & 2.75 \\
\hline 223.48 & 2.62 & 2.81 & 2.57 & 2.59 & 2.60 & 62.3 & 61.0 & 60.4 & 60.0 & 61.3 & 2.75 & 2.98 & 2.67 & 2.70 & 2.68 \\
\hline
\end{tabular}

Note: Percentages shown in parentheses under cross-sectional areas represent the percent change in area from the April 2005 survey. 
Appendix 1. Changes in cross-section geometry at permanent cross section li, Minebank Run study reach, 2005 through 2008. -Continued

[NGVD 29, National Geodetic Vertical Datum of 1929; ft, feet; ft², square feet; Apr., April; Nov., November; \%, percent]

\begin{tabular}{|c|c|c|c|c|c|c|c|c|c|c|}
\hline \multirow{2}{*}{$\begin{array}{l}\text { Elevation } \\
\text { (ft above } \\
\text { NGVD 29) }\end{array}$} & \multicolumn{5}{|c|}{$\begin{array}{c}\text { Cross-sectional area } \\
\left(\mathrm{ft}^{2}\right)\end{array}$} & \multicolumn{5}{|c|}{$\begin{array}{c}\text { Wetted perimeter } \\
\text { (ft) }\end{array}$} \\
\hline & $\begin{array}{l}\text { Apr. } \\
2005\end{array}$ & $\begin{array}{l}\text { Nov. } \\
2005\end{array}$ & 2006 & 2007 & 2008 & $\begin{array}{l}\text { Apr. } \\
2005\end{array}$ & $\begin{array}{l}\text { Nov. } \\
2005\end{array}$ & 2006 & 2007 & 2008 \\
\hline 224.00 & 44.2 & $\begin{array}{c}40.3 \\
(-8.8 \%)\end{array}$ & $\begin{array}{c}38.7 \\
(-12.4 \%)\end{array}$ & $\begin{array}{c}36.7 \\
(-17.0 \%)\end{array}$ & $\begin{array}{c}37.8 \\
(-14.5 \%)\end{array}$ & 30.2 & 31.6 & 30.4 & 29.8 & 30.4 \\
\hline 224.50 & 59.3 & $\begin{array}{c}55.5 \\
(-6.4 \%)\end{array}$ & $\begin{array}{c}53.4 \\
(-9.9 \%)\end{array}$ & $\begin{array}{c}51.3 \\
(-13.5 \%)\end{array}$ & $\begin{array}{c}52.7 \\
(-11.1 \%)\end{array}$ & 32.3 & 33.8 & 32.9 & 32.0 & 32.8 \\
\hline 225.00 & 75.5 & $\begin{array}{c}71.4 \\
(-5.4 \%)\end{array}$ & $\begin{array}{c}69.1 \\
(-8.5 \%)\end{array}$ & $\begin{array}{c}66.8 \\
(-11.5 \%)\end{array}$ & $\begin{array}{c}68.3 \\
(-9.5 \%)\end{array}$ & 34.8 & 35.7 & 34.8 & 34.5 & 34.7 \\
\hline 225.50 & 92.7 & $\begin{array}{c}88.4 \\
(-4.6 \%)\end{array}$ & $\begin{array}{c}85.8 \\
(-7.4 \%)\end{array}$ & $\begin{array}{c}83.9 \\
(-9.5 \%)\end{array}$ & $\begin{array}{c}85.1 \\
(-8.2 \%)\end{array}$ & 37.0 & 39.4 & 38.5 & 39.4 & 38.8 \\
\hline 226.00 & 110.9 & $\begin{array}{c}106.6 \\
(-3.9 \%)\end{array}$ & $\begin{array}{l}103.8 \\
(-6.4 \%)\end{array}$ & $\begin{array}{c}102.5 \\
(-7.6 \%)\end{array}$ & $\begin{array}{c}103.3 \\
(-6.9 \%)\end{array}$ & 39.5 & 41.7 & 40.9 & 41.8 & 41.1 \\
\hline 227.00 & 150.2 & $\begin{array}{c}146.2 \\
(-2.7 \%)\end{array}$ & $\begin{array}{l}142.7 \\
(-5.0 \%)\end{array}$ & $\begin{array}{c}142.8 \\
(-4.9 \%)\end{array}$ & $\begin{array}{c}142.5 \\
(-5.1 \%)\end{array}$ & 46.4 & 50.5 & 45.6 & 46.6 & 48.6 \\
\hline
\end{tabular}

\begin{tabular}{|c|c|c|c|c|c|c|c|c|c|c|c|c|c|c|c|}
\hline \multirow{2}{*}{$\begin{array}{l}\text { Elevation } \\
\text { (ft above } \\
\text { NGVD 29) }\end{array}$} & \multicolumn{5}{|c|}{$\begin{array}{l}\text { Hydraulic radius } \\
\text { (ft) }\end{array}$} & \multicolumn{5}{|c|}{$\begin{array}{c}\text { Channel width } \\
\text { (ft) }\end{array}$} & \multicolumn{5}{|c|}{$\begin{array}{c}\text { Mean channel depth } \\
\text { (ft) }\end{array}$} \\
\hline & $\begin{array}{l}\text { Apr. } \\
2005\end{array}$ & $\begin{array}{l}\text { Nov. } \\
2005\end{array}$ & 2006 & 2007 & 2008 & $\begin{array}{l}\text { Apr. } \\
2005\end{array}$ & $\begin{array}{l}\text { Nov. } \\
2005\end{array}$ & 2006 & 2007 & 2008 & $\begin{array}{l}\text { Apr. } \\
2005\end{array}$ & $\begin{array}{l}\text { Nov. } \\
2005\end{array}$ & 2006 & 2007 & 2008 \\
\hline 224.00 & 1.46 & 1.28 & 1.27 & 1.23 & 1.24 & 29.3 & 29.4 & 28.5 & 28.4 & 28.6 & 1.51 & 1.37 & 1.36 & 1.29 & 1.32 \\
\hline 224.50 & 1.84 & 1.64 & 1.62 & 1.60 & 1.61 & 31.1 & 31.1 & 30.6 & 30.1 & 30.6 & 1.91 & 1.78 & 1.75 & 1.70 & 1.72 \\
\hline 225.00 & 2.17 & 2.00 & 1.99 & 1.94 & 1.97 & 33.4 & 32.5 & 32.0 & 32.1 & 31.9 & 2.26 & 2.20 & 2.16 & 2.08 & 2.14 \\
\hline 226.00 & 2.81 & 2.56 & 2.54 & 2.45 & 2.51 & 37.6 & 37.5 & 37.1 & 38.2 & 37.3 & 2.95 & 2.84 & 2.80 & 2.68 & 2.77 \\
\hline 226.50 & 3.15 & 2.87 & 2.86 & 2.77 & 2.84 & 39.0 & 39.3 & 38.9 & 40.3 & 38.7 & 3.33 & 3.20 & 3.16 & 3.03 & 3.16 \\
\hline 227.00 & 3.24 & 2.90 & 3.13 & 3.06 & 2.93 & 43.9 & 45.6 & 41.1 & 42.5 & 44.0 & 3.42 & 3.21 & 3.47 & 3.36 & 3.24 \\
\hline
\end{tabular}

Note: Percentages shown in parentheses under cross-sectional areas represent the percent change in area from the April 2005 survey. 

Prepared by USGS West Trenton Publishing Service Center.

Edited by Valerie M. Gaine.

Graphics and layout by Timothy W. Auer.

For additional information, contact:

Edward J. Doheny, Hydrologist

443-498-5535

or Director, MD-DE-DC Water Science Center

U.S. Geological Survey

5522 Research Park Drive

Baltimore, MD 21228

443-498-5500

or visit our Web site at: http://md.water.usgs.gov 


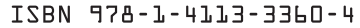

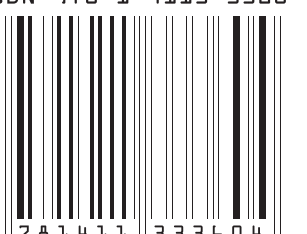

